\title{
Women in top echelon positions and their effects on sustainability: a review, synthesis and future research agenda
}

\author{
Mariasole Bannò $^{1}$ (D) Emilia Filippi ${ }^{2}$ (D) Sandro Trento $^{3}$ (D)
}

Accepted: 26 September 2021 / Published online: 26 October 2021

(c) The Author(s) 2021

\begin{abstract}
This article aims to review and systematize prior works that investigate how the presence of women in top echelon positions of firms affects sustainability and to create an agenda to guide future research in this promising area. In contrast to previous reviews, ours examines how women in top echelon positions affect sustainability by distinguishing both the position women held in the firm (i.e. Board of Directors-BoD, top management team, CEO and relevant committees) and the specific elements of sustainability (i.e. activity, performance, and disclosure). Our structured systematic review resulted in 187 publications retrieved from Web of Science and Scopus and revealed that the presence of women in top echelon positions is associated with greater engagement in social and environmental projects. Their presence also positively influences the environmental and social performance and increases the level, quality, and transparency of sustainability disclosure. Furthermore, the presence of women in top echelon positions and the implementation of sustainable activities improve both the firm financial performance and value. However, conflicting results have also emerged. On the basis of these findings, research gaps and future research agenda are identified and presented.
\end{abstract}

Keywords Gender · Board of directors · Managers $\cdot$ Sustainability $\cdot$ Systematic literature review

\section{Introduction}

In 1987, the concept of sustainable development, defined as the "development that satisfies the needs of the present generations without compromising the ability of the future ones to fulfill their own needs", was introduced (Sharma \& Henriques, 2005; WCED, 1987). Since 1987, sustainability, which refers to the balance

Mariasole Bannò

mariasole.banno@unibs.it

Extended author information available on the last page of the article 
of social, environmental, and economic criteria in business (e.g. Almeida \& Melo, 2017; Khan et al., 2016; Montiel, 2008; Saunila et al., 2019) has received increased attention in managerial practices and academia (e.g. Boyd et al., 2007; Walker et al., 2014). Firms need to meet the growing demands of consumers and stakeholders for sustainable initiatives and more detailed reporting on them (Baumgartner \& Ebner, 2010; Johnsen et al., 2017). Given the attention received in management practices, researchers are placing emphasis on understanding how sustainability is pursued and its activities are reported (Walker et al., 2014). As a result, a number of studies analysing this topic have emerged.

At the same time, the role of women in top echelon positions (Brunninge et al., 2007) has gained importance. In this review, the term "women in top echelon positions" is used with the goal of including all relevant positions in the firm that can be held by women. Specifically, in line with Brunninge et al. (2007), by top echelon positions we mean these roles: Board of Directors (BoD), top management team, CEO, and other relevant committees. Specifically, the composition of BoDs has been investigated since it is not only one of the main corporate governance instruments in the supervision of managerial actions, but also the body where decisions are taken on the strategic objectives of firms, including those related to sustainability (Akhmetshin et al. 2018; Ferramosca \& Verona, 2020). Instead, the composition of the top management team has been analysed with the aim to understand why organizations act and perform in a certain way (Hambrick, 2007; Hambrick \& Mason, 1984).

Capabilities and competencies of people in top echelon positions are, of course, unrelated to gender. However, the gender composition of BoDs and top management teams has widely attracted the attention of researchers and has been studied from numerous perspectives (for a review see e.g. Khatib et al., 2020; Tshetshema \& Chan, 2020), being sustainability one of these.

Recent studies have generally found that female directors positively affect firm sustainability and social responsibility, play a key role in ethically managing the sustainable activities of the firm and promote the adoption of ethical policies (see e.g. Gulzar et al., 2019; Nadeem et al., 2017). However, some authors state that board gender diversity has no effect on sustainability (Ajaz et al., 2020) or reduces the participation in sustainable development projects (Loukil et al., 2019). Regarding sustainability performance, several studies find that it is positively affected by board gender diversity (e.g. Elmagrhi et al., 2019; Hafsi \& Turgut, 2013; Provasi \& Harasheh, 2020; Yaseen et al., 2019). However, other authors find that board gender diversity improves the economic but not the environmental and social dimensions (Reyes Bastidas and Briano-Turrent, 2018). As concerns disclosure, while some studies state that the presence of female directors negatively influences sustainability disclosure (e.g. Fuadah et al., 2018) or does not impact on it (e.g. Dyduch \& Krasodomska, 2017; Khan, 2010; Mousa et al., 2018), other studies find positive effects on disclosure (e.g. Anazonwu et al., 2018; Formigoni et al., 2020) and specifically on its level (e.g. Al Fadli et al., 2019; Campanella et al., 2021; Dienes \& Velte, 2016; Ullah et al., 2019), quality (e.g. Said et al., 2018) and transparency (GarciaTorea et al., 2017). Finally, while board gender diversity may increase firm value through sustainability (e.g. Atif et al., 2021; Bektur \& Arzova, 2020; Qureshi et al., 
2020), other studies find contrasting results (e.g. Ajaz et al., 2020; Bristy et al., 2020). Similar conflicting results also emerge when considering the studies that analyse the presence of women as managers or CEOs (e.g. Buil-Fabrega et al., 2017; Martínez León et al., 2011; Pan et al., 2020).

In the literature there are already some reviews and meta-analyses that focus on the effect of corporate governance or BoDs on sustainability and CSR. ${ }^{1}$ For example, Naciti et al. (2021) conduct a review that analyses the evolution of corporate governance rules regarding sustainability. Regarding $\mathrm{BoD}$, the review of Rao and Tilt (2016b) examines how its diversity (e.g. in terms of gender, age, nationality, and functional background) affects CSR. Considering CSR reporting, Velte (2017) reviews existing studies to examine how board composition affects its quantity and quality, while the review of García-Sánchez (2020) focuses on how various factors including board composition and its diversity affect CSR disclosure and its external assurance. Regarding gender diversity, the review of Nguyen et al. (2020) examines the effect of female directors on corporate non-financial performance and observes that the majority of analysed studies yield a positive relationship between the two. Finally, in their review Amorelli and García-Sánchez (2020b) investigate how board gender diversity affects firm commitment to sustainability and stakeholder engagement focusing on some CSR dimensions (e.g. sustainability investment and performance), the theoretical frameworks adopted, and the moderating factors of the role of female directors

Existing meta-analyses show that there is a positive relationship between the presence of female directors and the implementation of sustainable activities (Endrikat et al., 2020), sustainability performance (Byron \& Post, 2016), and disclosure (Guerrero-Villegas et al., 2018; Lagasio \& Cucari, 2019; Majumder et al., 2017). In addition, the context in which the firm operates plays a role as country-level factors (e.g. institutions) moderate the relationship of female directors on sustainability (Endrikat et al., 2020; Majumder et al., 2017).

In comparison to existing reviews and following the future agenda advanced by Amorelli and García-Sánchez (2020b) who call for further analyses focused on specific elements of CSR, our review goes beyond and investigates how women in top echelon positions affect sustainability by distinguishing both the position women take in the firm (i.e. Board of Directors, top management team, CEO and relevant committees) and the specific elements of sustainability (i.e. activity, performance, and disclosure).

Given the relevance of the topic depicted also by the 2030 Agenda and the 17 Sustainable Development Goals (including gender equality), the contrasting conclusions yielded by previous studies and the limitations of previous literature reviews, this paper identifies and systentizes existing literature on the presence of women in top echelon positions and its effect on sustainability with the purpose to compare and contrast the findings of prior studies. Thus, our literature review provides

\footnotetext{
1 As explained in more detail in the methodology section, the concepts of sustainability and CSR are converging (Montiel, 2008).
} 
readers with a state-of-the-art understanding of the research topic, by identifying research gaps and signalling future research avenues.

More in detail, a structured systematic review was performed yielding 187 publications, retrieved through Web of Science and Scopus. Without foreclosing our analysis on any topic and taking an exploratory and deductive approach, our review revealed four main topics of analysis on which women in top echelon positions have an effect: (1) Sustainable activities and strategies (both social engagement and environmental); (2) Sustainability performance (both social and environmental); (3) Sustainability disclosure (level or extent, quality, and transparency); (4) Sustainability effects on firm performance and value (through the moderating role of women in top echelon positions on sustainable activities, performance, and disclosure).

Our review contributes to the academic debate on the issue in three ways. We consider women in all top echelon positions, without restricting the analysis on female directors, as in previous reviews on the topic. We bring clarity and order by offering a novel perspective of existing studies through the identification of four main topics. Furthermore, we contribute to the theoretical advancement by identifying the major research gaps and suggesting future research avenues. These aspects are essential for advancing the study of how the presence of women in top echelon positions affects sustainability.

The remaining part of this paper is structured as follows. In Sect. 2, the methodology used is outlined. Section 3 presents the descriptive statistics of the selected publications and an overview of prior research. Finally, the discussion of managerial and policy implications and future research is outlined in Sect. 4.

\section{Literature review methodology}

Based on Tranfield et al. (2003), a structured systematic literature review was performed. For identifying potential sources for reviewing, we select the Web of Science $(\mathrm{WoS})$ and Scopus databases. ${ }^{2}$

The search was not subject to publication time criteria and was performed on 1 st June 2021.

To identify relevant publications, we first decided the search strings to use. Search strings to be included or excluded in the final search were discussed among the authors with regular meetings; this has helped us overcome the lack of a preliminary "scoping study" that is recommended by Tranfield et al. (2003) with the aim of evaluating the size and relevance of the literature and obtaining objective criteria for delimiting the topic of the review (Nguyen et al., 2020). The final search string was composed by three parts: the first focuses on female presence using female $*$ OR $w o *^{*} n$ OR gender; the second focuses on the role of women using bod OR board

\footnotetext{
2 These databases have many advantages: they are readily updated; they offers the most valuable collection of data; they are considered as the most reliable, relevant and prestigious database for literature reviews; they ensure that all types of publications are manually selected and scanned with the aim to include only high-impact studies (see e.g., Caputo et al., 2018; Falagas et al., 2008; Naciti et al., 2021).
} 
OR corporate AND governance OR manager* OR management; the third focuses on sustainability using sustainab* OR CSR OR corporate AND social AND responsibility. We preferred to use very general terms so as to conduct a research that would remain broad and open-ended. Explaining the themes of analysis in the keywords would in fact have generated limitations in the research.

Search strings had to be contained in the title, abstract and keywords. ${ }^{3}$ The studies selected in this way needed to relate to one of these areas: Business, Business Finance, Economics, Environmental Science, and Management. Furthermore, the search was carried out with inclusion criteria (i.e. both quantitative and qualitative studies) and exclusion criteria (i.e. publications whose abstract is not written in English, public media like editorials) (Tshetshema and Kai-Ying Chan, 2020).

For this review, the concepts of sustainability and corporate social responsibility (CSR) must be distinguished. Sustainability refers to the balance of social, environmental, and economic criteria in business, while CSR "encompasses the economic, legal, ethical, and discretionary expectations that society has of organizations at a given point in time" (Carroll, 1979). However, according to Montiel (2008), these two concepts are converging because of "their shared environmental and social concern (...) despite their paradigmatic differences". For this reason, in our literature review, the term sustainability, as defined by WCED (1987) is preferred and adopted.

The following information was extracted from the selected publications:

1. Bibliographic reference (author, year of publication, journal);

2. Gender-related findings, gender effect and topic;

3. Type of female involvement (i.e. Board of Directors, top management team, CEO and relevant committees);

4. Lens theory (i.e. theoretical approach);

5. Methodology (e.g. qualitative, quantitative) and data (e.g. cross-sectional, panel data);

6. Sample characteristics ( sample size, firm characteristics ${ }^{4}$ );

7. Year and country of analysis.

The search in Web of Science and Scopus yielded 902 and 329 publications, respectively. From the combination of the two databases, carried out in order to eliminate duplicates, an initial set of 1169 publications was obtained. Following Moher et al. (2009), the publications were first filtered by reading the title and abstract. If this analysis did not lead to a final decision regarding inclusion, the whole text was

\footnotetext{
3 There are two popular methods for determining highly convenient inclusion criteria (Paul and Criado, 2020); in the first one, keywords decided by the authors are generally found directly in the title, abstract or list of keywords; in the second one, keywords can be also found in the full text of the article, apart from in its title or abstract.

4 In our review we also found samples made of data on: banks, financial institutions and mutual funds; hotels; board members and managers; business directors and purchasing professionals; appointment announcements for chief executives of the sustainability area to existing or newly created positions by US listed firms.
} 


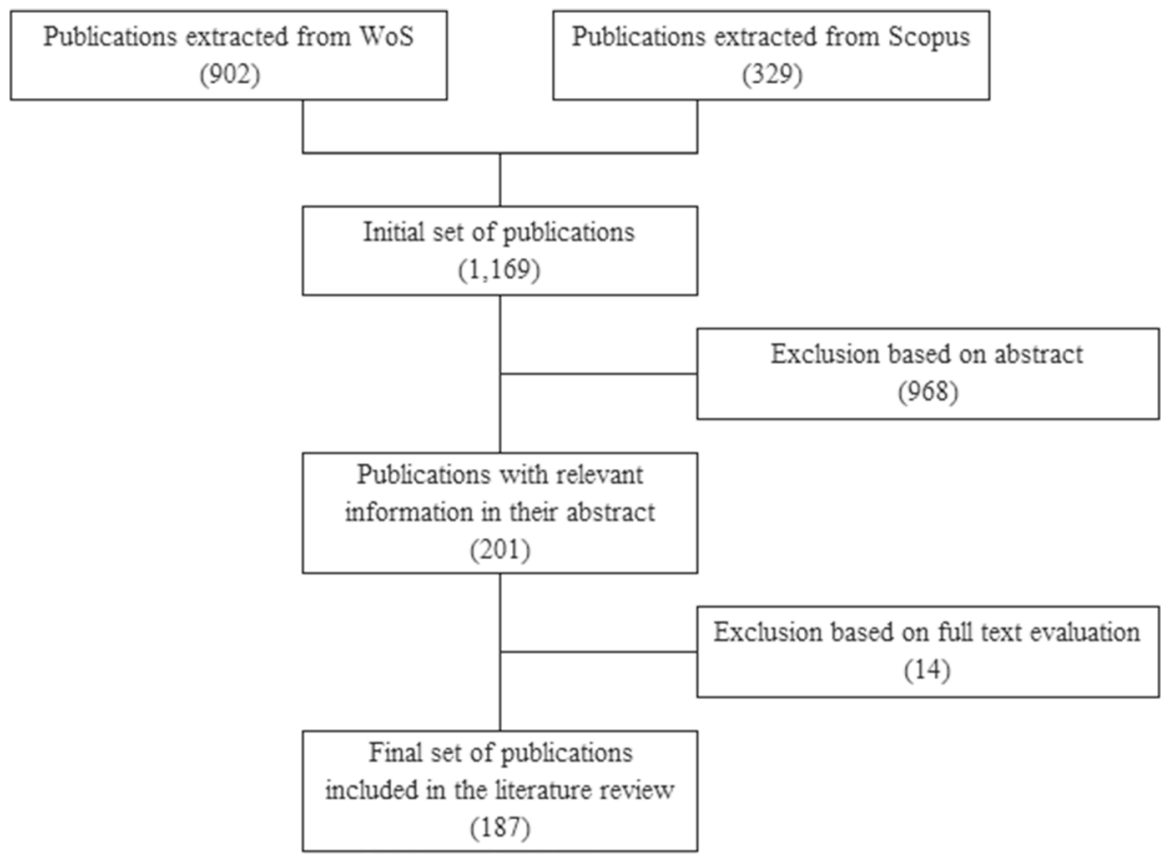

Fig. 1 Literature selection process and results, updated on 1st June 2021. Our elaboration from Moher et al. (2009)

read and analysed. We used our knowledge, judgment and experience many times for deciding upon clear selection criteria (i.e. exclusion/inclusion) of publications in our sample. After exclusions based on abstract and an evaluation based on full text evaluation, we obtained the final set of 187 publications (see Fig. 1). Then, a black-box approach was used to conceptualise the relationship between the presence of women in top echelon positions and sustainability (Mengis, 2020). Specifically, to identify the main thematic results, we adopted an inductive approach. The inductive analysis "refers to approaches that primarily use detailed readings of raw data to derive concepts, themes, or a model through interpretations made from the raw data by an evaluator or researcher" (Thomas, 2006). We therefore allow our thematic themes to emerge from the analysis of the raw data (i.e. a careful reading of the selected publications), without imposing restrictions and having a priori expectations (Thomas, 2006). We categorized the sample literature based on the explicit construct addressed by each study. In doing this, any intermediate factors (e.g. control variables) were ignored because this research is specifically interested in the direct effects of female presence under various contextual conditions. The final categorization of the publications into the emerging themes was reached through discussions among the authors. 


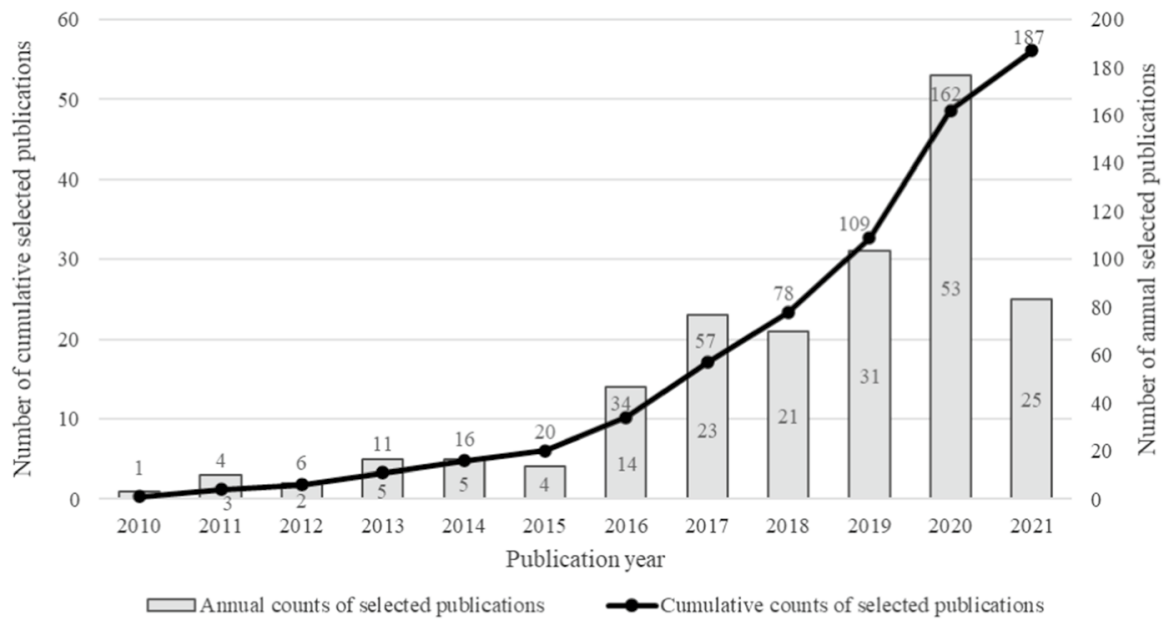

Fig. 2 Cumulative and annual counts of selected publications, updated on 1st June 2021. Our elaboration

\section{Results of the review}

In this section, we first offer a discussion of the main methodological and empirical issues. Then we elaborate the topics that emerged from our review of the literature into the thematic results by considering theoretical and empirical findings on female presence in top echelon positions and the effect on sustainability. We outline the selected publications in the Appendix.

\subsection{Methodological and empirical issues}

\subsubsection{Bibliographic reference (author, year of publication, journal)}

As Fig. 2 shows, literature on sustainability has grown exponentially since 2010 .

The list of journals that published at least two of the selected publications is reported in Table 1. Corporate Social Responsibility and Environmental Management, Sustainability, and Business Strategy and the Environment published the most studies $(31,22$, and 19, respectively), indicating a concentration in these three journals of $38 \%$ of the selected publications. Instead, there are 55 journals with only one selected publication each on gender and sustainability.

\subsubsection{Type of female involvement (e.g. board of directors, top management team, CEO and relevant committees)}

160 studies analyse the role of female directors (e.g. Guping et al., 2020; PuchetaMartinez and Gallego-Alvarez, 2019; Rao \& Tilt, 2016a); 24 examine the presence of female managers (e.g. J. Graafland, 2020; Lu et al., 2020a, 2020b); 13 consider 
Table 1 Academic journals with more than one selected publications, updated on 1st June 2021

Publication Title

Corporate Social Responsibility and Environmental Management

Sustainability

Business Strategy and the Environment

Corporate Governance: The international journal of business in society

Journal of Business Ethics

Journal of Cleaner Production

Meditari Accountancy Research

Social Responsibility Journal

Academy of Accounting and Financial Studies Journal

Sustainability Accounting, Management and Policy Journal

Accounting \& Finance

Australian Accounting Review

Estudios Gerenciales

International Journal of Disclosure and Governance

Journal of Corporate Finance

Management Decision

The Journal of Asian Finance, Economics and Business

\section{Number of} selected publications

31

19

11

11

10

4

4

3

3

2

2

2

2

2

2

2

Our elaboration

the role of female CEOs (e.g. Criado-Gomis et al., 2020; Kabongo et al., 2013; Przychodzen et al., 2018); instead only two studies focus on women in the audit committee (i.e. Appuhami \& Tashakor, 2017; Bravo \& Reguera-Alvarado, 2018) while only one on women in the CSR committee (Elmaghrabi, 2021). ${ }^{5}$ Therefore, it emerges the greater attention paid to the role of female directors, which may be linked to the ease with which the data necessary for analysis can be obtained.

\subsubsection{Lens theory}

Several theories have been used in the field, however our literature review reveals seven main theoretical approaches that guided past research, based on the management literature. As can be seen from Table 2, the most common theoretical perspectives utilized in the literature are: Stakeholder theory (66 studies), Agency theory (53 studies), Resource dependence theory (37 studies), Legitimacy theory (24 studies), Upper echelons theory (24 studies), Critical mass theory (17 studies), Institutional theory (17 studies).

\footnotetext{
${ }^{5}$ Note: In this phrase, studies that examine multiple positions held by women are counted multiple times.
} 
Table 2 Theoretical approach employed by the selected publications, updated on 1st June 2021

Theoretical approach Number of selected publi- Percentage cations

\begin{tabular}{|c|c|c|}
\hline \multicolumn{3}{|c|}{$\begin{array}{l}\text { Distribution of selected publications by number of theories } \\
\text { used }\end{array}$} \\
\hline Paper relying on one theory & 57 & 30 \\
\hline Paper relying on two theories & 55 & 29 \\
\hline Paper relying on three theories & 14 & 7 \\
\hline Paper relying on multiple theories (at least four) & 27 & 14 \\
\hline Paper relying on no (explicit) theory & 34 & 18 \\
\hline Total & 187 & 100 \\
\hline \multicolumn{3}{|l|}{ Theories used in at least two selected publications } \\
\hline Stakeholder theory & 66 & 22 \\
\hline Agency theory & 53 & 18 \\
\hline Resource dependence theory & 37 & 13 \\
\hline Legitimacy theory & 24 & 8 \\
\hline Upper echelons theory & 24 & 8 \\
\hline Critical mass theory & 17 & 6 \\
\hline Institutional theory & 17 & 6 \\
\hline Gender socialization theory & 9 & 3 \\
\hline Social role theory & 8 & 3 \\
\hline Resource-based view & 7 & 2 \\
\hline Signaling theory & 5 & 2 \\
\hline Dependency theory & 4 & 1 \\
\hline Complexity theory & 3 & 1 \\
\hline Feminist care ethics & 3 & 1 \\
\hline Neo-institutional theory & 3 & 1 \\
\hline Resource-based theory & 3 & 1 \\
\hline Diversity theory & 2 & 1 \\
\hline Homophily & 2 & 1 \\
\hline Social identity theory & 2 & 1 \\
\hline Socioemotional wealth theory & 2 & 1 \\
\hline Stakeholder-agency theory & 2 & 1 \\
\hline Token theory & 2 & 1 \\
\hline Total & 295 & 100 \\
\hline
\end{tabular}

Our elaboration

The gender-specific approaches include only two frameworks dedicated and originated as gender studies: the Critical mass theory (17 studies) and the Gender socialization theory ( 9 studies). What emerges is that most of the theories used in the selected publications to explain and frame gender issues are frameworks for explaining behavior based on values humans place on social group membership, but are not born and declined specifically for gender issues (i.e. social categorization theory, social identity theory, relational demography theory, self-construal theory). 
They all refer to social perception that can generate prejudice, which is then used as an explanation of gender issues. Theories that are not gender-specific are then the most employed. Finally, we also found theories that look at heterogeneity but are not born and declined specifically for gender issues (i.e. diversity theory and complexity theory). These are theoretical approaches that, unlike social frameworks, emphasize the positive aspects generated by diversity/heterogeneity.

All these theories, both gender specific and non specific ones, are applied regardless of the position of women.

In total, 51 different theoretical perspectives are explicitly employed on this topic. Finally, there are 34 studies that do not explicitly rely on any theory.

\subsubsection{Methodology (e.g. qualitative, quantitative) and data (e.g. cross-sectional, panel data)}

The reviewed studies are mainly based on quantitative methods, with the exception of two qualitative studies (Cuadrado-Ballesteros et al., 2017; Rao \& Tilt, 2020) and two studies that adopted a mixed method approach (Dwekat et al., 2020; Mahmood et al., 2018). The empirical studies apply a wide range of regression methods including, among others: ordinary least squares, probit, logit, ordered, binomial, 2SLS, generalized method of moments, fixed effects regressions, and structural equation model. Of the 183 quantitative studies, the majority of studies use cross-sectional data, while some employ panel data or longitudinal design (e.g. Fahad \& Rahman, 2020; Ramon-Llorens et al., 2021; Shahbaz et al., 2020; Uyar et al., 2020). This review highlights, therefore, a lack of conceptual and qualitative studies on the way the presence of women in firms affects sustainability.

\subsubsection{Sample characteristics (sample size, firm characteristics) and year and country of analysis}

Our review highlights that the subject of analysis is generally medium to large publicly listed firms (e.g. Arayssi et al., 2020; Kilincarslan et al., 2020; Rejeb, 2017; Zahid et al., 2020), with three exceptions that examined small and medium enterprises (i.e. Courrent et al., 2016; Graafland, 2020; Sancho et al., 2017). Fifty-five studies use multi country data (e.g. García-Sánchez et al., 2020b; Valls Martínez et al., 2020), of which 9 studies focusing only on European contexts (e.g. Ben Fatma \& Chouaibi, 2021; Gangi et al., 2021; Nuber \& Velte, 2021). 132 studies analyse the data of only one country; the most considered countries are geographically distributed and include: United States (26 studies), China (15 studies), Australia (12 studies), Spain (11 studies), Malaysia (7 studies), United Kingdom (7 studies), France (7 studies), Bangladesh (6 studies), Pakistan (5 studies), Italy (5 studies), Canada (4 studies). This degree of internationality is perhaps not surprising given the fact that sustainability is crucially important in many economies around the world (Amorelli and García-Sánchez, 2020a). However, there are a number of important regions where research in gender and sustainability is underrepresented in the journal literature, including Eastern Europe, Africa, Latin America, and Asia, despite the 


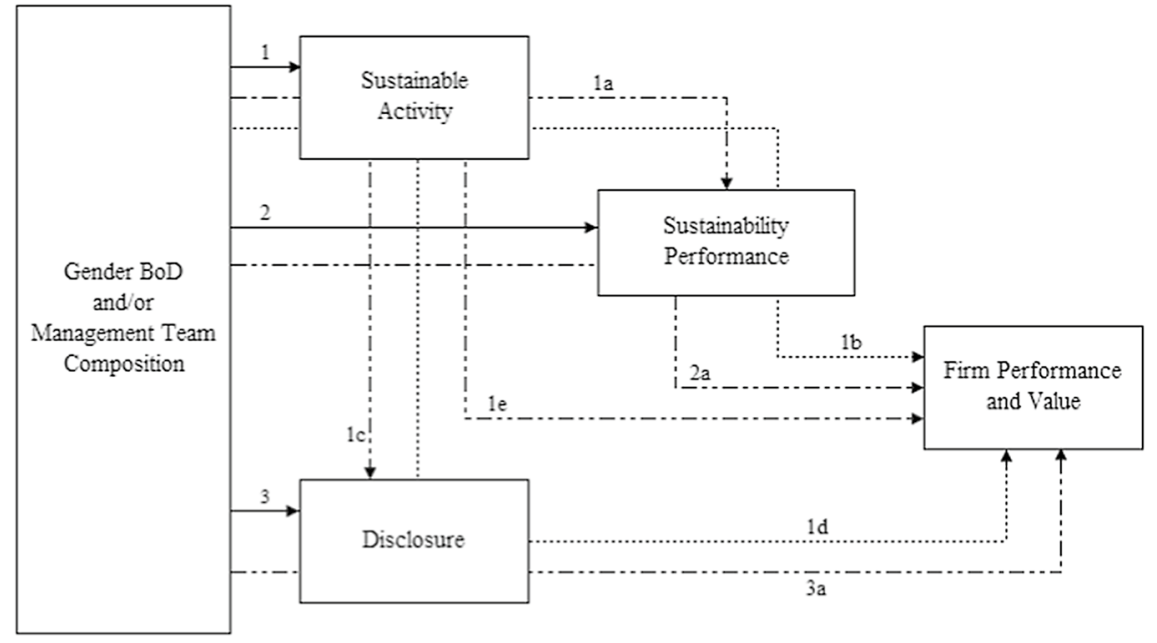

Note:

1 Sustainable Activity

1a Sustainable Activity - Sustainability Performance

1b Sustainable Activity - Sustainability Performance - Firm Performance and Value

1c Sustainable Activity - Disclosure

1d Sustainable Activity - Disclosure - Firm Performance and Value

1e Sustainable Activity - Firm Performance and Value

2 Sustainability performance

2a Sustainability performance - Firm Performance and Value

3 Disclosure

3a Disclosure - Firm Performance and Value

The thematic result Firm Performance and Value is included in 1b,1d, 1e, 2a, and 3a; the direct relationship analysis between gender and firm performance and value is not the object of our literature review.

Fig. 3 Framework for organizing selected publications on gender and sustainability. Our elaboration

importance of these regions to understanding the role of female presence in different contexts (Khan et al., 2019a, 2019b).

\subsection{Thematic results}

Following the procedure described in Sect. 2, the influence of women in top echelon positions on sustainability was categorized with reference to these topics: (1) sustainable activities and strategies, (2) sustainability performance, (3) sustainability disclosure, (4) sustainability effects on firm performance and value. As regards topic 4, we should specify that under this label we consider the effect that one or more sustainability dimensions (i.e. sustainable activities and strategies, sustainability performance, sustainability disclosure) have on the firm performance and value. The emergence of the four issues is consistent with the terms used in the meta-analyses on the topic that were identified and set forth in the introduction. 


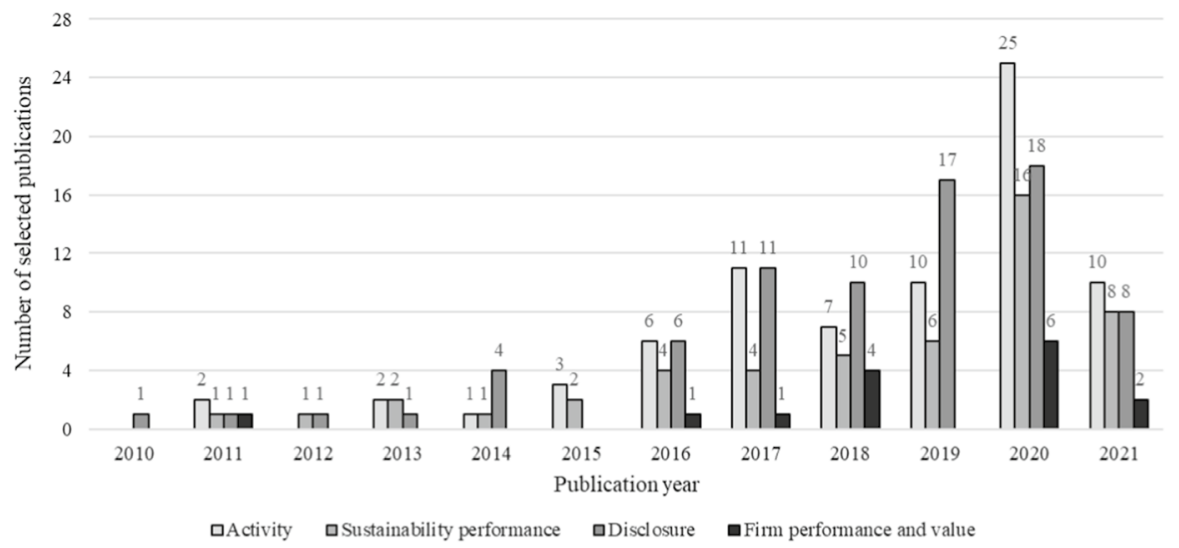

Fig. 4 Number of selected publications for each topic, updated on 1st June 2021. Source: Our elaboration

The main findings presented in the literature were translated into a framework shown in Fig. 3, while Fig. 4 reports the distributions of the identified topics from 2010 to 2021. The rest of the section presents a review of research on each of these thematic results.

\subsubsection{Sustainable strategy and activities}

Seventy-nine studies investigate the relationship between gender in top echelon positions and sustainable activities, of which 50 find a positive relationship, 4 a negative relationship, 14 mixed results and 11 no relationship. Almost all analysed studies examine the effects of the presence of women on sustainable activities by distinguishing according to their position.

Many studies reveal a positive relationship between the presence of female directors and sustainable activities (see e.g. Beji et al., 2020; Rehman et al., 2020; Saheed Olanrewaju et al., 2020). Female directors not only positively affect corporate sustainability, but they also play a key role in "enabling firms to ethically manage their social responsibilities and sustainable practices" (Yasser et al., 2017) and in promoting the adoption of equality, diversity and inclusion policies (Bruna et al., 2014). While having a positive effect on CSR, female directors also decrease corporate social irresponsibility (Boukattaya \& Omri, 2021). Arayssi et al. (2016) state that the presence of female directors "favourably influences on a firm's risk and performance through promoting a firm's investment in effectual social engagements and reporting on them". Female directors facilitate the use of the firm's scarce resources towards social projects that maximize value (Jizi, 2017) and encourage the firm's affiliation with the United Nations Global Compact (Martínez-Ferrero et al., 2020). ${ }^{6}$

\footnotetext{
${ }^{6}$ In the case of banks, those with more female members on their boards incline toward socially responsible behaviour, especially in greater regulatory and stronger investor protection environments (GarcíaSánchez et al., 2018). Gender diversity increases sustainability expenditure of banks (Hosain, 2020) while it decreases their energy usage (Fakoya and Nakeng, 2019). On the contrary, Gallego-Sosa et al. (2020) find no significant differences between banks' commitment to the planet on the basis of board gender diversity.
} 
The educational background, talent, and experience of female directors is important in the adoption of sustainable environmental initiatives (García Martín \& Herrero, 2020): therefore the presence of talented women in the firm allows them to manage social responsibility and sustainable practices in an appropriate way (Setó-Pamies, 2015).

On the contrary, Loukil et al. (2019) state that "the presence of female independent directors reduces firm involvement in sustainable development projects". Instead, some studies find that board gender diversity has no effect on sustainability (e.g. Ajaz et al., 2020; Ardito et al., 2020; Zaid et al., 2020). Finally, other studies find mixed results. For example, it results that female directors are beneficial for sustainability engagement only if they are not members of the controlling family, while they foster philanthropic engagement only if they are members of the controlling family (Campopiano et al., 2019). According to Cullinan et al. (2019), while female independent directors are positively associated with sustainability, this is not true for female executive directors.

While Yarram and Adapa (2021) observe that gender diversity positively influences total sustainability but not its individual components, other studies find that female directors influence both environmental and social sustainable activities.

Regarding environmental sustainability, many studies find that female directors are positively related to attitudes towards environmental protection (e.g. Cosma et al., 2021), the pursuit of environmentally friendly strategies (Glass et al., 2016), carbon reduction initiatives (Haque, 2017), corporate environmental investment (Hu \& Yang, 2021), and a higher probability that the firm takes part in sustainabilitythemed alliances (Post et al., 2015). ${ }^{7}$ Environmental sustainability initiatives are positively influenced by gender diversity, in both demographic (i.e. the percentage of women on the BoD or in top management positions) and structural terms (i.e. firm policies and practices that enable or reinforce gender diversity) (Kassinis et al., 2016). According to Shoham et al. (2017), firms increase their involvement in environmental sustainability as soon as they appoint a woman to the BoD; however, this decision is strongly influenced by the culture of the countries in which the organization operates (Xie et al., 2020). Moreover, the likelihood of a firm to create pollution is moderated by the positive relationship between the presence of female directors and the environmental policy of the firm ( $\mathrm{Li}$ et al., 2017). All these positive effects of female directors on environmental sustainability can explain the choice of majority family owners and dual-class owners to appoint female directors with the charge to advance "their personal preferences for environmental corporate social responsibility" (Cordeiro et al., 2020).

On the contrary, Galbreath (2011) highlights that despite the important role of women in sustainable activities, it could happen that due to sex-based biases and stereotyping, men directors ignore the suggestions from female directors on aspects regarding environmental quality with the consequence that female directors are not significantly associated with environmental quality. Wei et al. (2017) specify that when there are only one or two female directors on the board, no significant

\footnotetext{
7 The positive association between gender diversity and environmental sustainability is also valid in the case of banks (Birindelli et al., 2019).
} 
relationship on environmental investment can be seen; however, when the number of female directors reaches at least three, they have a significantly positive effect on it but only in state-owned firms and firms from heavily-polluting industries.

Moving to social activities, the presence of female directors (as well as in top and middle management) has a positive effect on sustainable activities with gender equality objectives (Larrieta-Rubín de Celis et al., 2015).

The effect of gender diverse boards on sustainability dimensions varies depending on the type of stakeholder: this diversity positively affects sustainability dimensions that are associated with stakeholders with less power (e.g. the environment, contractors, and the community), but it does not affect sustainability dimensions that are related to stakeholders with more institutionalized power (e.g. employees and customers) (Francoeur et al., 2019). In the interaction with various stakeholders, female directors are able to talk with them and to satisfy their needs, reducing the risk of their negative reactions, which can damage firm profits (Galbreath, 2011).

Finally, female participation on BoDs has an effect on specific aspects. Together with board independence, board gender composition affects sustainable supply chain responsibility through three channels: CEO duality, sustainability committee, and sensitive industries (Benjamin et al., 2019).

Focusing on female managers, conflicting results emerge. According to some studies, environmental and social commitments are greater for female managers (Buil-Fabrega et al., 2017). Female managers positively affect "corporate sustainable competitive advantage, which included both the inhibiting effect on unethical environmental behavior and the stimulating effect on proactive environmental strategies" (Pan et al., 2020). Moreover, compared to men, female managers tend to implement diversity and labor flexibility policies related to work schedule and flexible work as part of their sustainability (Arredondo Trapero et al., 2013). On the contrary, according to Q. Lu et al., (2020a, 2020b), the relationship between the presence of female top managers and sustainability is negative especially for firms in a market with a low marketization level. Instead, some studies find that the presence of women on the top management team does not affect sustainability practices (e.g. Prudêncio et al., 2021), both regarding sustainability as a whole or each of its dimensions (economic, social and environmental) (Martínez León et al., 2011). More in detail, Courrent et al. (2016) show how manager characteristics like gender, age, experience, and training do not influence a firm's pursuit of social activities, while their personal values (measured using ethics and local territorial belonging) do influence these activities. For example, in the purchase of products, it seems that on average, purchasing managers are willing to pay a premium for products that are compliant with the United Nations Global Compact; this willingness is not affected by the gender of the purchasing managers (Goebel et al., 2018). Finally, mixed results were found by $\mathrm{Wu}$ et al. (2019), according to which while existing female executives or top managers stimulate corporate philanthropy (and this relationship is influenced by the firm controller and the degree of industry competition), they do not affect the scale of philanthropy.

Regarding female CEOs, Galbreath and Tisch (2020) find that women in the operations manager role foster environmentally sustainable practices, while women in the CEO role do not. However, when women are in both CEO and operations 
manager roles in the same firm, the relationship with environmentally sustainable practices is positive.

If we analyse the relationship between the presence of women and sustainable activities and strategies considering the role they play, it emerges that the literature is almost unanimous in stating that female directors have a positive effect on sustainable activities. Conversely, when analyzing the position as manager, the results are mixed, perhaps due to the small number of studies. One common finding from the analyses on the effect of women in the two positions (i.e. in BoD or top management team) is that the results are positively influenced by the demographic, educational, and cultural characteristics of the women (Courrent et al., 2016; Kassinis et al., 2016; Xie et al., 2020). Instead, too few studies are related to the CEO and other committee positions to draw conclusions.

\subsubsection{Sustainability performance}

Fifty studies investigate the relationship between women in top echelon positions and sustainability performance, of which 37 find a positive relationship, 2 a negative relationship, 7 mixed results and 4 no relationship. Of course, the environmental and social performance depends on various factors (Fig. 3). First of all, strategies regarding sustainability play a key role: "firms with more effective CSR strategies exhibit better environmental and social performance" (Orazalin \& Baydauletov, 2020). However, sustainability performance also depends on both BoD characteristics (e.g. size, independency, diversity, and activity) and corporate characteristics (e.g. firm size, leverage, and growth opportunities), which, when properly combined, lead to high levels of social responsibility performance (Cuadrado-Ballesteros et al., 2017).

Biswas et al. (2018) confirm this result, finding that "firms with higher board gender composition, greater board independence and sustainability committees tend to have better social and environmental performance". Furthermore, even board gender diversity alone positively affects the sustainability performance as confirmed by several studies (e.g. Chams and Garcia-Blandon, 2019; Govindan et al., 2021; Lu \& Herremans, 2019; Romano et al., 2020; Uyar et al., 2021). The positive relationship between female directors and sustainability performance is higher when there are female chairs within the board CSR committee (Eberhardt-Toth, 2017) and when the firm has a consumer market orientation (Hyun et al., 2016) or operates in a maledominated industry (Zaichkowsky, 2014) or has an environmental and social risk exposure (Naveed et al., 2021).

Other studies find opposite results. Specifically, Fakir and Jusoh (2020) and García-Sánchez et al. (2020a) find no relationship between female directors and sustainability performance. Two studies demonstrate a return on investment in sustainable activities decreasing with the proportion of female directors (Bristy et al., 2020; Zhuang et al., 2018). Finally, mixed results are found by for example Alazzani et al. (2019) and Ardito et al. (2020). Zhang (2012) finds that while there is a positive relationship between board gender diversity and institutional strength and technical strength of sustainability, the relationship is not significant when considering the weakness ratings of sustainability performance. 
Some studies consider the environmental and social performance achieved by firms. While these two aspects of sustainability are usually pursued together, it could happen that one aspect is more important than the other due to the influence of culture and institutional context. For example, the Malaysian culture drives firms to place more importance on the social performance strictly linked to human orientation than on other dimensions (e.g. economic, environmental and marketplace aspects) (Alazzani et al., 2017). Considering both the environmental and social performance, Shaukat et al. (2016) find that the board gender diversity enables a more proactive and comprehensive sustainability strategy, thus leading to a higher environmental and social performance. On the contrary, according to Reyes Bastidas and Briano-Turrent (2018) female directors (or CEOs) positively affect the economic dimension, but worsen the environmental and social dimensions.

Focusing on environmental performance, some studies find a positive relationship between female directors and environmental performance (e.g. Lopatta et al., 2020; Orazalin \& Mahmood, 2021). As anticipated in the previous section, the participation in sustainability-themed alliances, associated with a high representation of women on the BoD, positively affect the corporate environmental performance (Post et al., 2015). ${ }^{8}$ Considering both sustainability strategy and environmental performance, Orazalin and Baydauletov (2020) find that the positive relationship between these two aspects is negatively affected by the board gender diversity. Finally, Nadeem et al. (2020) and Nguyen et al. (2021) find no relationship between female directors and environmental performance.

Considering the social performance, while according to Landry et al. (2016) female directors increases the probability of the firm to appear on lists measuring ethics or organizational quality (e.g. the Most Admired Companies, the Most Ethical Companies, the Best Companies to Work for, and the Best Corporate Citizens), according to Sanan (2016) there is no significant association between gender diversity of boards and social performance.

A greater gender balance in top-management increases sustainability performance (McGuinness et al., 2017). Female managers also positively affect the firm's environmental performance with the "development of eco-friendly products and commitment to resource reduction" (Burkhardt et al., 2020). On the contrary, Lu et al. (2019) find that a U-shaped relationship between female managers and sustainability performance exists.

Regarding female CEOs, it was found that they positively affect sustainability performance (Huang, 2013). This positive effect is evident both in polluting and non-polluting firms, which are able to significantly reduce pollutant emissions (Jiang \& Akbar, 2018).

\footnotetext{
${ }^{8}$ In the case of banks, Jahid et al. (2020) and Matuszak et al. (2019) find that female directors have a significant positive effect on sustainability disclosure. On the contrary, Buallay et al. (2020) and Birindelli et al. (2018) find that the relationship between women on the board of directors and a bank's sustainability performance is an inverted $\mathrm{U}$-shape. A nonlinear relationship has also been found between the presence of female directors and the environmental performance of the bank; this relationship is highly shaped by female CEOs (Birindelli et al., 2019).
} 
If we analyse the effect of women on sustainability performance considering the role they play, it emerges how female directors lead to mixed results in this case. Specifically, the role of women in other committees emerges in this regard. On the other hand, if one analyses the position as manager, the results are mostly in agreement in detecting positive effects. Also in this case, there exist too few studies in relation to the position of CEO to draw considerations.

\subsubsection{Sustainability disclosure}

The presence of women in top echelon positions also has an effect on sustainability disclosure through "documents intended to inform all stakeholders of the economic, social and environmental impacts of corporate performance, with respect to a given period of time" (García-Sánchez et al., 2019). Seventy-seven studies investigate this relationship, of which 55 find a positive relationship, 5 a negative relationship, 8 mixed results and 9 no relationship.

The presence and number of female directors positively affects firm's disclosure (e.g. Alia \& Mardawi, 2021; Frias-Aceituno et al., 2013; Girón et al., 2020; Peng et al., 2021). Several aspects are positively affected: the level or extent of disclosure (e.g. Issa \& Fang, 2019; Ong \& Djajadikerta, 2018), its quality (e.g. Khan, Khan, \& Senturk, 2019a, 2019b; Mahmood \& Orazalin, 2017; Vitolla et al., 2020), its transparency (Garcia-Torea et al., 2017), its lower risk of impression management strategies (i.e. the risk that these reports are a "result of opportunistic behaviour, by which managers can disclose biased information"; García-Sánchez et al., 2019). Finally, female participation on BoDs is among the factors that predict the engagement of firms in the assurance regarding sustainability disclosure, which is recognized as a means to increase its reliability, and that affect the choice of the provider with a preference towards auditing professionists (Buertey, 2021; Liao et al., 2018). On the contrary, some studies state that the presence of female directors negatively influences sustainability disclosure (e.g. Cucari et al., 2018; Gallego-Alvarez and Pucheta-Martinez, 2020b) or does not have any effect on it (Giannarakis, 2014; Giannarakis et al., 2014; Yusoff et al., 2019). Finally, other studies find mixed results: according to Biswas et al. (2021) female directors who are affiliated to the governing family, founders and other board members reduce disclosure in family firms; instead, unaffiliated female directors enhance disclosure both in family and non-family firms.

According to critical mass theory (Dahlerup, 2006), the number of female directors that produces significant effects on firm's disclosure is identified as at least three by for example Amorelli and García-Sánchez (2020a) and De Masi et al. (2021). In this regard, Alazzani et al. (2017) suggest that the (insufficient) number of female directors considered in their analysis may have led to the conclusion that there is a "moderate relationship between board gender diversity and CSR disclosure". Instead, according to Manita et al. (2018), even when the critical mass (three female directors) is reached, no significant relationship between board gender diversity and sustainability disclosure is found.

Regarding the quality of disclosure, García-Sánchez et al. (2019) state that female directors produce "more balanced, comparable and reliable information", even if at 
the same time they are associated with "less precise and clear information, given their narrative character"; these effects are larger in more stakeholder-oriented countries. Al-Shaer and Zaman (2016) specify that when female directors are independent, the quality of sustainability reporting is amplified with respect to the presence of non-independent female directors. However, Amorelli and García-Sánchez (2020a) highlight that the positive role of women on voluntary information disclosure does not remain when they become CEO: in fact, when they reach this position, female directors start to adopt a "a male stereotype regarding voluntary information disclosure", regardless of the human capital of the directors.

Focusing on environmental disclosure, there is a positive relationship between the presence of female directors and environmental disclosure (Rao et al., 2012; Yusoff et al., 2016), including the likelihood of disclosing information regarding climate change (Ararat \& Sayedy, 2019; Ben-Amar et al., 2017), carbon (Hossain et al., 2017), corporate greenhouse gas emissions (Hollindale et al., 2019; Tingbani et al., 2020). ${ }^{9}$ The board gender diversity is among the factors that determines the quality of environmental disclosure (Baalouch et al., 2019). On the contrary, according to Kılıç and Kuzey (2019), the presence of female directors is not associated with the carbon disclosure index and the decision of a firm to respond to the Carbon Disclosure Project. A similar result is found by Post et al. (2011), according to which reaching this critical mass does not affect the disclosed environmental corporate social responsibility.

Regarding the effect of female managers, Dilling and Caykoylu (2019) find a significant negative correlation between integrated report quality and the ratio of female executives. ${ }^{10}$

Gender diversity in the audit committee characteristics has a significant positive influence on the level of CSR disclosure and on the CSR environmental disclosure (Appuhami \& Tashakor, 2017). It also increases the quality of voluntary sustainability reporting both in terms of comprehensiveness and relevance, as women may operate as monitoring mechanisms in the increasing commitment to provide valuable sustainability information and to display greater stakeholder orientation (Bravo and Reguera-Alvarado, 2018). ${ }^{11}$

If we analyse the role of women on sustainability disclosure considering the position they held, it emerges that the literature is almost unanimous in stating that female directors have a positive effect on sustainability disclosure albeit with due

\footnotetext{
9 The positive effect of female directors on environmental disclosure has also been found in the case of banks. Specifically, Gallego-Alvarez and Pucheta-Martinez (2020a) find that female directors of banks encourage the reporting of environmental information in countries with coordinated market economies.

10 Regarding other entities, Garde Sánchez et al. (2017) observe that the gender of the manager in state owned enterprises is not statistically significant in influencing the disclosure of CSR information. In the case of banks, Prabowo et al. (2017) find that the presence of female executives positively affects CSR disclosure, especially in banks listed on the stock market. The effect of female managers is observed only in medium and larger banks and in banks without government ownership (Prabowo et al., 2017).

11 Some studies also consider the effects that female directors produce on the sustainability disclosure of particular entities. For example, according to Tapver et al. (2020), the positive association between the proportion of women on the board and sustainability disclosure also exists in the case of banks. In the case of state-owned enterprises, when female directors are the majority, it seems (i.e. there are weak indications) that the total sustainability information disclosed decreases (Argento et al., 2019).
} 
specification. This relationship is, in fact, the most analysed in the literature and, therefore, the most exhaustive and articulated in describing how the characteristics of the board enter into the relationship. The same considerations apply to the committees that in this case are more investigated. Therefore, a similar relationship emerges between women in the BoD and relevant committees and sustainability disclosure. Viceversa, if one considers the position as manager, the results are mixed, perhaps, once again, due to the small number of studies.

\subsubsection{Sustainability effects on firm performance and value}

Only 15 studies analyse the relationship between the presence of women in top echelon positions (in which they moderate sustainable activities, performance, and disclosure) and the financial performance of the firm and its value. Of these studies, 9 find a positive relationship, 2 a negative relationship, 3 mixed results and one no relationship. ${ }^{12}$ Among others, Chong et al. (2018) highlight the need of firms to "engage in sustainable development to maximise the firms' value" and stress the essential role of women in defining the strategy regarding these activities.

Board gender diversity can increase firm value by promoting renewable energy consumption (Atif et al., 2021) or by promoting sustainability disclosure (Bektur \& Arzova, 2020). In fact, sustainable activities will be appreciated by the stakeholders and lead to "more beneficial contracting and opening new avenues of growth" (Qureshi et al., 2020), which will be valued on the market and result in higher stock prices. In this mechanism, board gender diversity is extremely important, as firms with higher diversity tend to disclose more regarding sustainable activities, as exposed in the previous section. Furthermore, Arayssi et al. (2016) demonstrate that the presence of female directors "favorably influences on a firm's risk and performance through promoting a firm's investment in effectual social engagements and reporting on them".

Contrasting results are reported in few studies. Ajaz et al. (2020) state that there is a negative relationship between board gender diversity, sustainability performance and a firm's financial performance, while there is no significant relationship with the firm's reputation. Bristy et al. (2020) demonstrate that the return on investment in sustainable activities decreases with the proportion of female directors.

In the case of managers, it has been found that gender diversity in top management teams increases the level of implementation of sustainability, with an effect on firm performance (Quintana-García et al., 2018).

Female CEOs and CFOs also have a positive effect on firm performance through the promotion of sustainability. The appointment of a chief executive in the area of sustainability can improve the financial performance, as the "company shows its commitment to sustainability and social responsibility to its stakeholders" and this positive image "may have signaling effects for its customers, employees, and shareholders" (Wiengarten et al., 2017). The greatest benefits can be obtained if this female executive has a

\footnotetext{
12 The direct relationship analysis between gender and firm performance and value is not the object of our literature review.
} 
background in functions related to sustainability (Wiengarten et al., 2017) and is an independent director rather than a male executive director (Atif et al., 2020).

Female CFOs also improve firm performance such as debt cost saving as they conduct more environmentally responsible activities, whose effects are more prominent in high risk firms (Wang et al., 2021).

It is difficult to analyse the effect of women in top echelon positions on firm performance and value considering the role they play, given the small number of studies. However, it seems to emerge that the effect tends to be positive regardless of position in the Bod, top management team, as CEO or in relevant committees.

\section{Women in top echelon positions}

Table 3 is a summary table showing the effect that women in the various positions held in the firm (BoD, managers, CEO) are able to exert on the various dimensions of sustainability (i.e. sustainable activities and strategies; sustainability performance; sustainability disclosure; sustainability effects on firm performance and value). As can be observed, most studies identify a positive relationship between women and sustainability: women, whatever position they hold in the firm, have a positive effect on sustainability, whether measured by sustainable activities and strategies, sustainability performance, sustainability disclosure, or sustainability effects on firm performance and value.

The relationships between women in the BoD and the four sustainability topics are not only the most numerous, but they are also those studied paying more attention to other aspects besides the gender variable. Specifically, regardless of the relationship analysed, socio-demographic and educational (e.g. García Martín \& Herrero, 2020), cultural (e.g. Alazzani et al., 2017), institutional (e.g. García-Sánchez et al., 2019), firm (e.g. Hyun et al., 2016; Naveed et al., 2021), and industry (e.g. Zaichkowsky, 2014) factors were also considered in the analysis. Specific cases relating to particular sectors (e.g. food sector as in García-Sánchez et al., 2020a; oil, gas and mining as in Saheed Olanrewaju et al., 2020); logistics as in Govindan et al., 2021; electronics and chemical as in Post et al., 2011) and specific types of business (e.g. family firms as in Campopiano et al., 2019) were also explored in this report. Probably, as already mentioned, such attention and scientific production is also due to the greater availability of data.

\section{Concluding remarks}

A subject advances when prior studies are logically synthesized based on their findings (Kumar et al., 2020). After doing this, we developed a comprehensive future research agenda with reference to methodology and empirical issues, theory constructs, and thematic issues. Before revealing the agenda, we present managerial and policy implications.

\subsection{Managerial and policy implications}

The analysis revealed that generally the presence of women, whatever position they hold in the firm, is associated with a greater engagement in social and environmental projects 


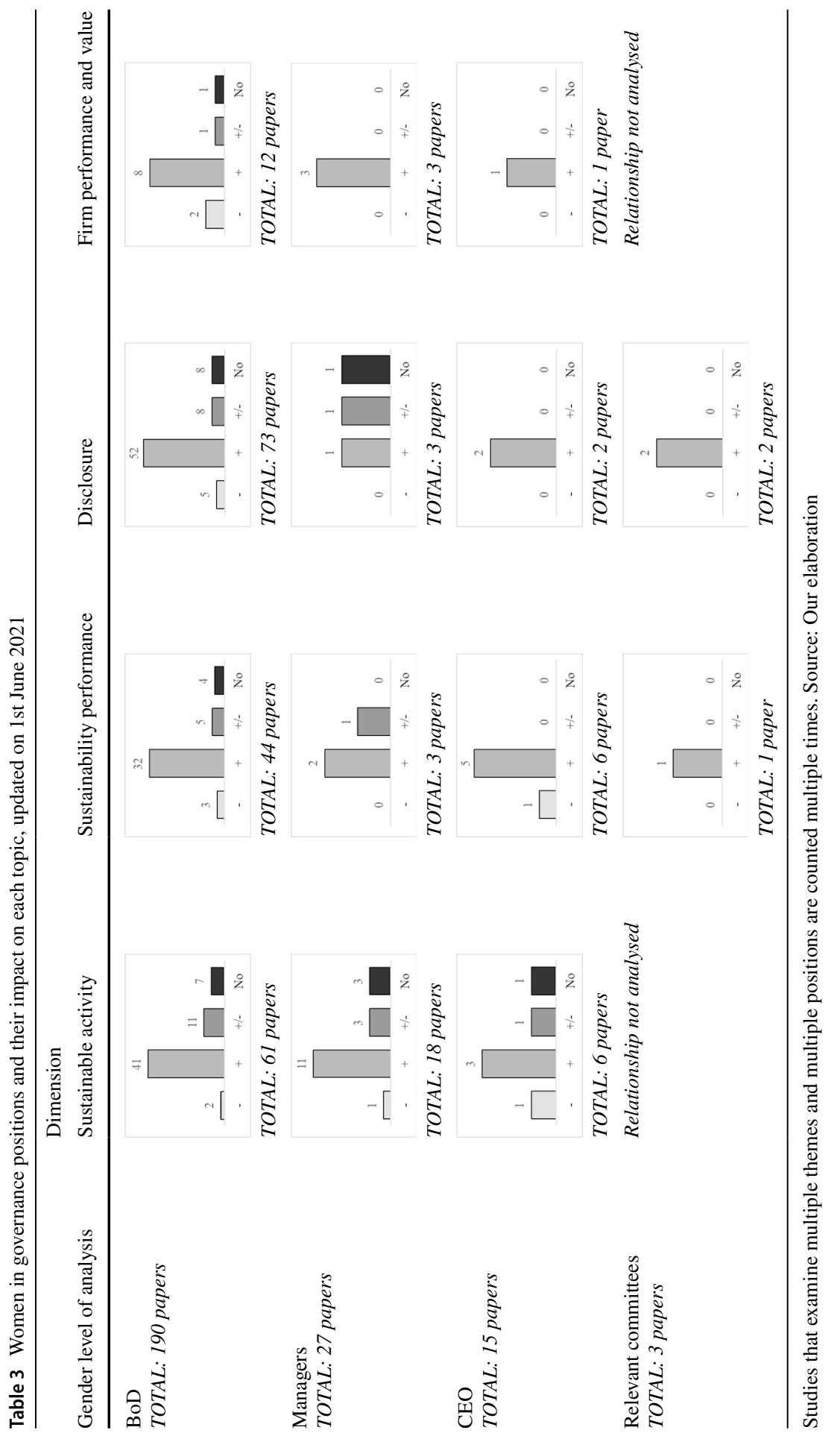


Table 4 Suggested direction for future research

\begin{tabular}{|c|c|}
\hline \multicolumn{2}{|c|}{ Theoretical approach } \\
\hline \multicolumn{2}{|c|}{ Methodological and empirical issues } \\
\hline Suggestion 1 & Search for a unified theory \\
\hline Suggestion 2 & Use of both qualitative and mixed methods \\
\hline Suggestion 3 & $\begin{array}{l}\text { Consideration of women in some top echelon positions (e.g. CEO and relevant } \\
\text { committees) }\end{array}$ \\
\hline Suggestion 4 & Consideration of women in non-top echelon positions \\
\hline Suggestion 5 & $\begin{array}{l}\text { Analysis of underrepresented contexts: regions (i.e. Eastern Europe, Africa, Latin } \\
\text { America, and Asia) and firm governance and size (i.e. family firms and small } \\
\text { firms) }\end{array}$ \\
\hline \multicolumn{2}{|l|}{ Thematic issues } \\
\hline Suggestion 6 & $\begin{array}{l}\text { Analysis of the impact of women in top echelon positions on firm performance and } \\
\text { value }\end{array}$ \\
\hline Suggestion 7 & $\begin{array}{l}\text { Further analysis of how women in top echelon positions positively or negatively } \\
\text { impact sustainability }\end{array}$ \\
\hline Suggestion 8 & $\begin{array}{l}\text { Investigation of the types of sustainable activities (e.g. innovation) promoted by } \\
\text { women }\end{array}$ \\
\hline Suggestion 9 & $\begin{array}{l}\text { Consideration of the influence of the institutional context on the relationship } \\
\text { between gender and sustainability }\end{array}$ \\
\hline Suggestion 10 & Consideration of the level of disclosure required by different countries \\
\hline
\end{tabular}

Our elaboration

(e.g. Činčalová \& Hedija, 2020; Galbreath, 2016; Prudêncio et al., 2021), positively influences their performance (e.g. Deschênes et al., 2015; Jouber, 2021), increases the level and the quality of their disclosure (e.g. Javaid Lone et al., 2016; Tamimi \& Sebastianelli, 2017), and contributes to enhancing firm performance and value (e.g. Atif et al., 2021; Bektur \& Arzova, 2020). On the basis of the central issues and key results that have emerged, important managerial and policy implications are highlighted.

Firms can observe how the presence of women in top echelon positions may have a positive effect on their sustainability. Our results could therefore inspire a new path for women inside businesses: increasing the number of women on BoD or, more in general, in other top echelon positions.

Furthermore, findings suggest that policymakers should consider the presence of women on the BoD when designing laws affecting environmental and social sustainability and when deciding whether to participate in private firms. As both gender diversity and/or the presence of a critical mass in top echelon positions may foster sustainability, policy makers should implement specific actions to stimulate such a virtuous relationship.

\subsection{Future research agenda}

\subsubsection{Methodological and empirical issues}

Our discussion of the main methodological and theoretical findings on female presence in top echelon positions and sustainability allowed us to identify some important gaps that can be analysed in future research. A summary is offered in Table 4. 
5.2.1.1 Suggestion 1 Despite the fact that many studies have considered the relationship between women in top echelon positions and social and/or environmental sustainability, there is no unified theory behind the commitment to sustainability. We argue that the theoretical support for the possible link between gender in top echelon positions and sustainability comes from the two most prominent theories and a specific gender theory: Stakeholder theory (as for sustainability), Upper echelons theory (as for characteristics of BoD and/or top management teams) and Gender socialization theory (as for gender).

5.2.1.2 Suggestion 2 Our review highlights a lack of conceptual and theoretical studies on the way the presence of women in firms affects sustainability. Only two studies employed a qualitative approach and two a mixed method. For these reasons, the first item on our agenda aims to assess how the inclusion of both qualitative (e.g. interviews, case studies and longitudinal studies) and a mixed methods design will improve our understanding of the interplay between gender and sustainability. Usually, the analysis of both phenomena is performed using quantitative methods because data collection is usually indirect. However, this can limit understanding of the interplay we seek to explore (Creswell \& Plano Clark, 2018). For example, only with qualitative studies it would be possible to investigate in more detail how women influence two relevant aspects: the decision making process of BoD that leads or not to the pursuing of sustainability in the firm; and the implementation of sustainable activity and disclosure with its effects. As a consequence, the combination of quantitative statistical trends and in-depth understanding given by qualitative research techniques can create a stronger research methodology than a single approach (Bryman, 2008).

5.2.1.3 Suggestion 3 The analysis of the effect of women on sustainability considering some top echelon positions they hold is scarce. Specifically, while the studies about the $\mathrm{BoD}$ are proliferating since 2010 , almost scarce are the ones analysing the top management team, CEO and relevant committees. We argue that there is a need to better understand the influence of the demographic, educational, and cultural characteristics of the women in these unexplored specific positions. Currently, too few studies are related to the relevant committee as CEO and in relevant committees to draw conclusions.

5.2.1.4 Suggestion 4 Although it is people in top echelon positions that generally strongly influence the decisions of a firm and their implementation, it may be interesting to examine how women in other positions (particularly staff level female workers) influence the sustainability of the firm. To the best of our knowledge, no study has focused on the effect of women in non-top echelon positions on firm sustainability. Female workers, together with male workers, may play a key role in the execution of sustainable activities decided at higher firm levels, with a significant effect on the performance of these activities (on the contrary, they have no effect on disclosure, which remains the sole responsibility of the higher bodies). The influence of the lower corporate levels on sustainable activities may be particularly relevant in smaller 
organisations with a less hierarchical structure, in which employees are more empowered, responsible and autonomous, as they can directly propose solutions and ideas, take decisions, and solve firm issues. For this reason, it is possible that the best ideas, which are then implemented, come from the most skilled workers that are not on the BoD or top management teams.

5.2.1.5 Suggestion 5 There are a number of important regions where research in gender and sustainability is underrepresented in the literature; as such we suggest exploring the contexts of: Eastern Europe, Africa, Latin America, and Asia. We believe that analysing the influence of women in top echelon positions in different contexts could advance the field given that country-level factors (e.g. institutions) moderate the effect of female directors on sustainability (Endrikat et al., 2020; Majumder et al., 2017). Furthermore, the analysed samples are almost exclusively representative of medium and big listed firms. We suggest further analysis considering firm heterogeneity, and specifically that related to governance and size, which can help shed further light on the issue. Both the dimension (smaller firms) and the ownership structure (family concentrated or not) should be taken into account as they both represent more than $80 \%$ of world wide firms (Family Firm Institute, 2020).

\subsubsection{Thematic issues}

The framework used to reveal the emerging findings allowed the identification of some important topics that should be analysed in future research. A summary is offered in Table 4.

5.2.2.1 Suggestion 6 Among the four identified thematic issues (i.e. sustainable activities and strategies, sustainability performance, sustainability disclosure), the effect that women have on firm performance and value is underexplored. In fact, the majority of studies (126 out of 187) examine the effect of women only on sustainable activities or disclosure, without assessing the effect on performance. Instead, 61 studies estimate achieved performance (either at the sustainability or firm level), but only 15 assess how women, through sustainability, effect on performance at the firm level. This is surprising because if on the one side sustainability is a central issue, on the other one performance and continuous growth is the main goal of every firm (Goyal et al., 2013). Today, it is more correct to talk about sustainable growth as sustainability is the only viable way to continue doing business in the coming decades. Therefore, our suggestion is to further analyse the relationship between the presence of women in top echelon positions, sustainability and firm performance and value.

5.2.2.2 Suggestion 7 Among the four topics, there is not a dominant controversial theme. However, each of the thematic results confirm a non-unanimously-positive effect of the presence of women in top echelon positions. This is particularly true when analysing the roles women play. Therefore, we suggest deepening the topics concerning sustainable activities and strategies, sustainability performance, sustain- 
ability impact on the firm performance and value by considering the specific role of women in the top management team, CEO and relevant committees.

5.2.2.3 Suggestion 8 With regard to sustainable activities, it would be interesting to examine through which activities the firm seeks to achieve superior sustainability performance. Specifically, innovation can play a key role in achieving this goal (Lopatta et al., 2020; Nadeem et al., 2020). For example, in the case of environmental sustainability, it could be interesting to understand to what extent the presence of women in the firm increases innovation aimed at obtaining less polluting finished products or at producing with a lower environmental impact (i.e. by acting on the productive aspect). The implications of these changes on the firm's environmental performance should then be examined.

5.2.2.4 Suggestion 9 BoDs and top management teams play a critical role in implementing sustainable activities and policies and their gender composition may have important consequences on that (Kabir \& Thai, 2021; Yasser et al., 2017). For example, Nielsen and Huse (2010) note that "women may be particularly sensitive to- and may exercise influence on-decisions pertaining to certain organizational practices, such as corporate social responsibility and environmental politics". In addition to gender, the institutional context should be considered as it has a prominent role in shaping both individual differences in personality traits (Wood and Eagly, 2002) and individual perceptions of others. We argue that other studies are needed in order to understand the different possible effects of women in top echelon positions on sustainability, for example by comparing egalitarian versus male oriented contexts. Indeed, just a few studies analysed the effects of a stereotypical view within the organization on sustainability (e.g. Galbreath, 2011). We suggest considering the social constructs of gender in different institutional contexts (i.e. egalitarian versus non-egalitarian) and how stereotyped views may affect their attitude toward sustainability. This suggestion is particularly important when studying the presence and therefore the role of women according to their position.

5.2.2.5 Suggestion 10 In the analysis of sustainability disclosure, future research should consider the context to a greater extent. Specifically, since the laws that require firms to provide information on non-economic aspects differ among countries and in different contexts and given that firms may disclose non-economic information for different reasons, it may be interesting to understand how the presence of women in top echelon positions influences sustainability disclosure by comparing the level of disclosure required by law and that offered by firms (Fernandes et al., 2018). In fact, existing studies (e.g. Fernandez-Feijoo et al., 2014) consider only the presence or absence of laws of this kind, but not the level of disclosure that they require of firms. It could also be interesting to analyse the reasons and factors underlying the emerging higher levels of disclosure provided by firms (de Villiers \& Dimes, 2021) in comparison to that required by law. 


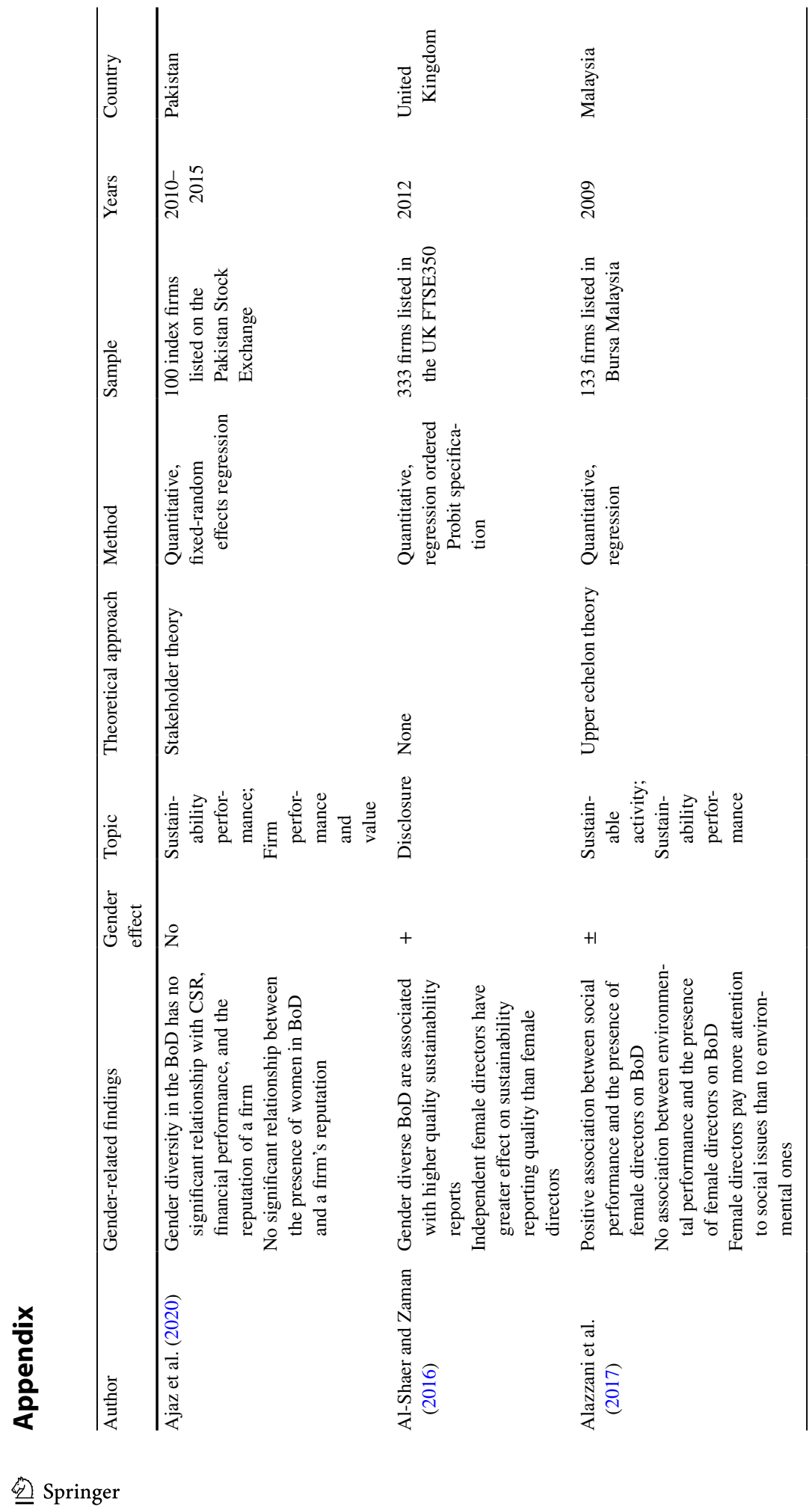




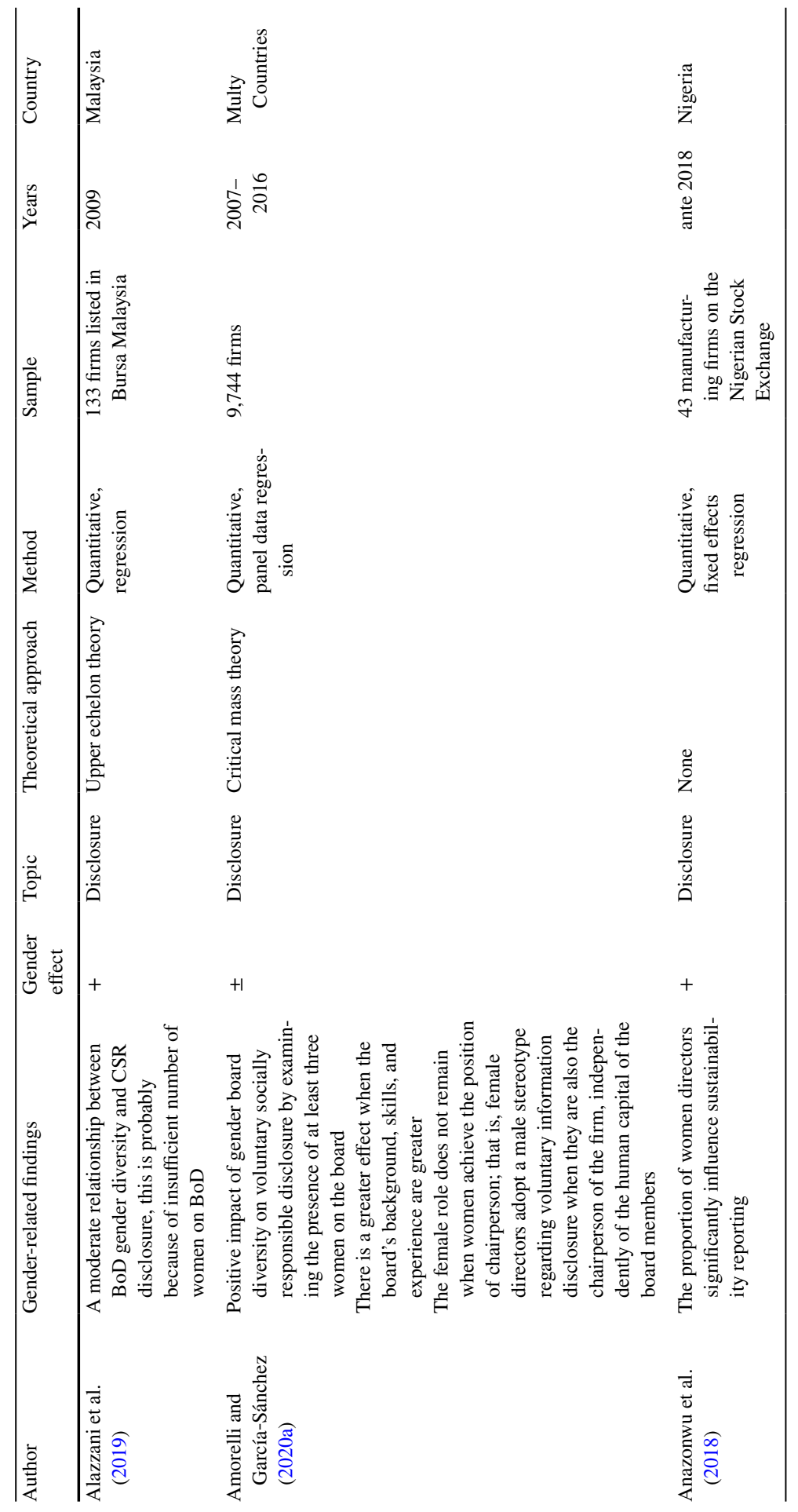




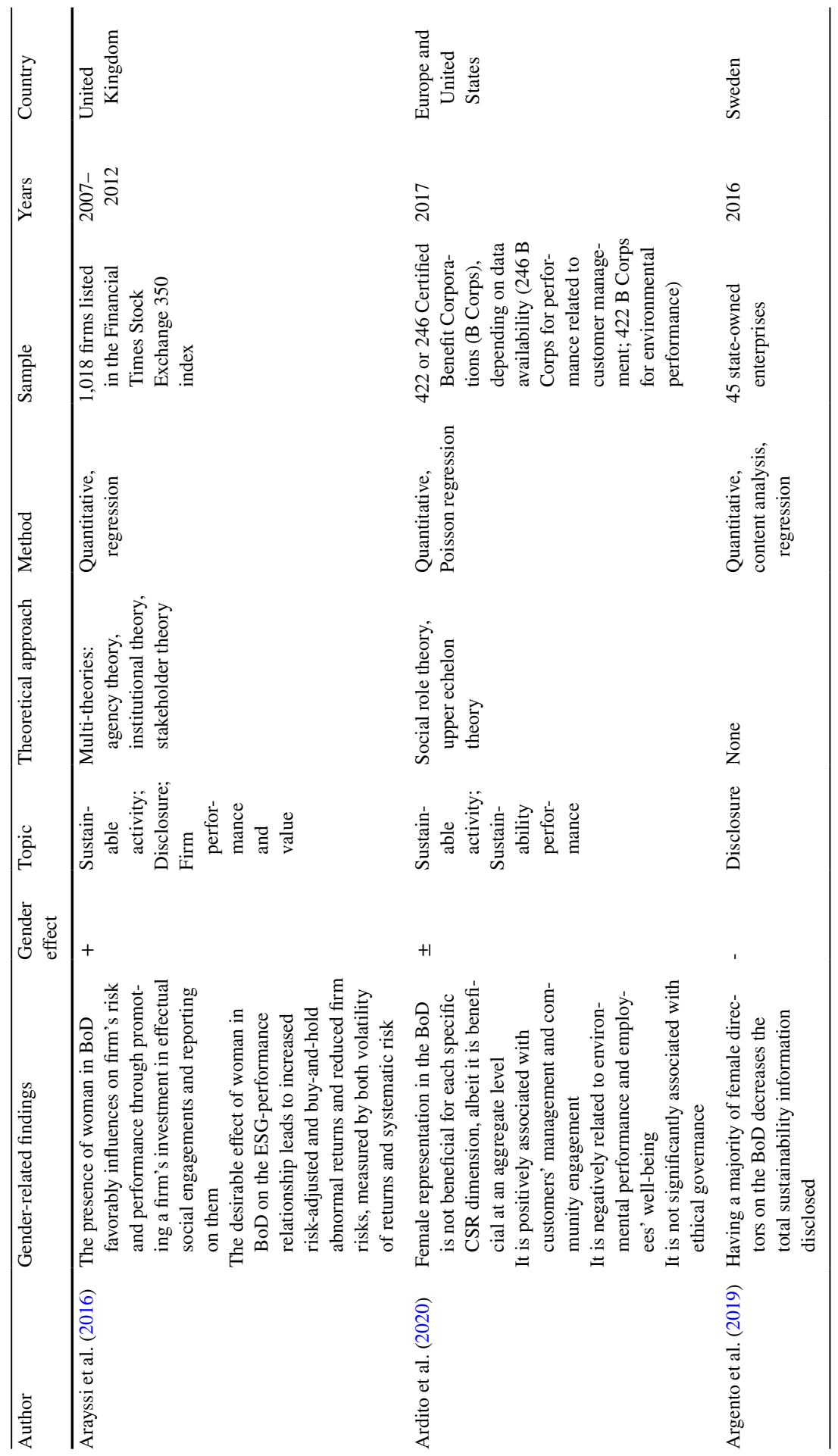




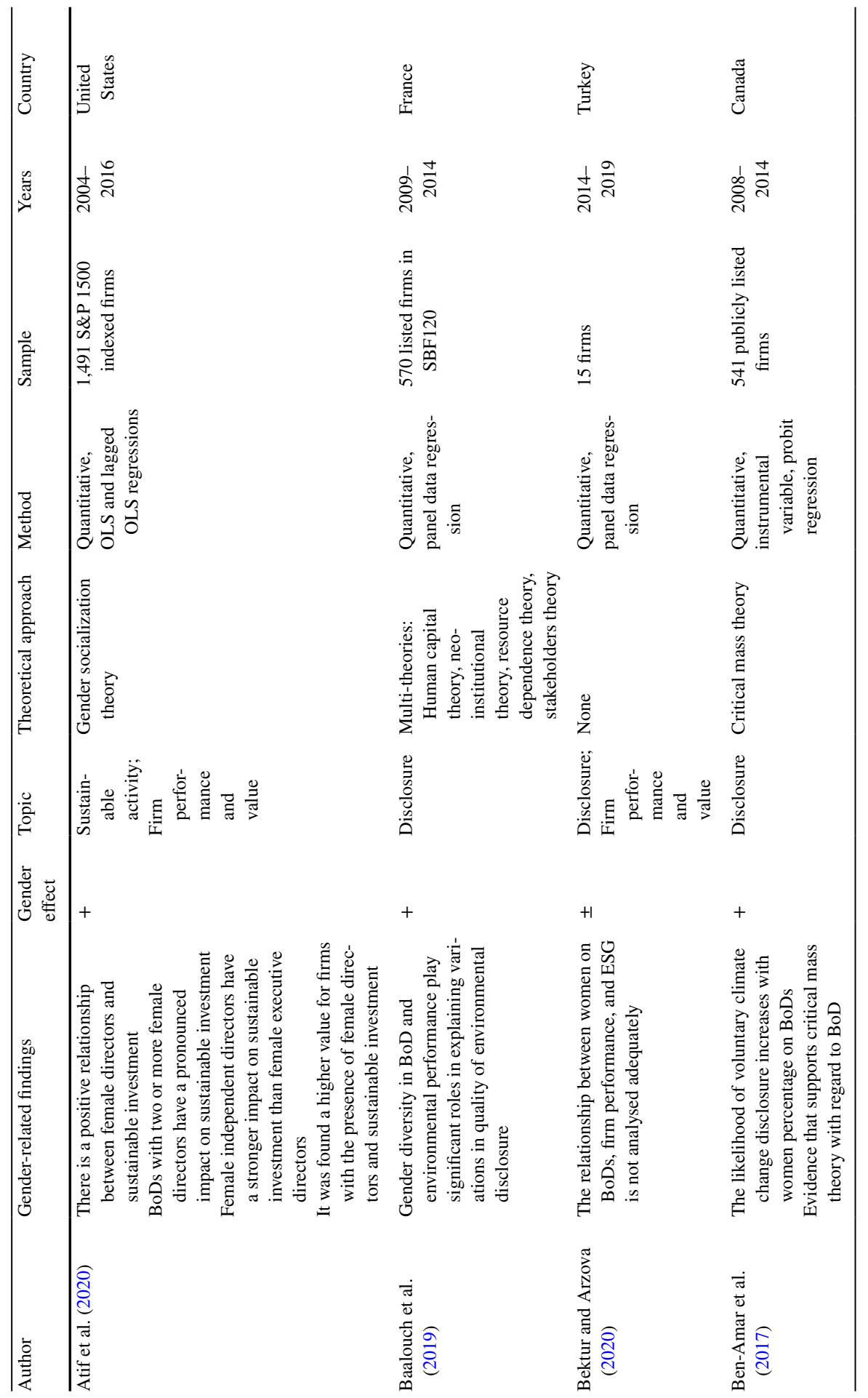




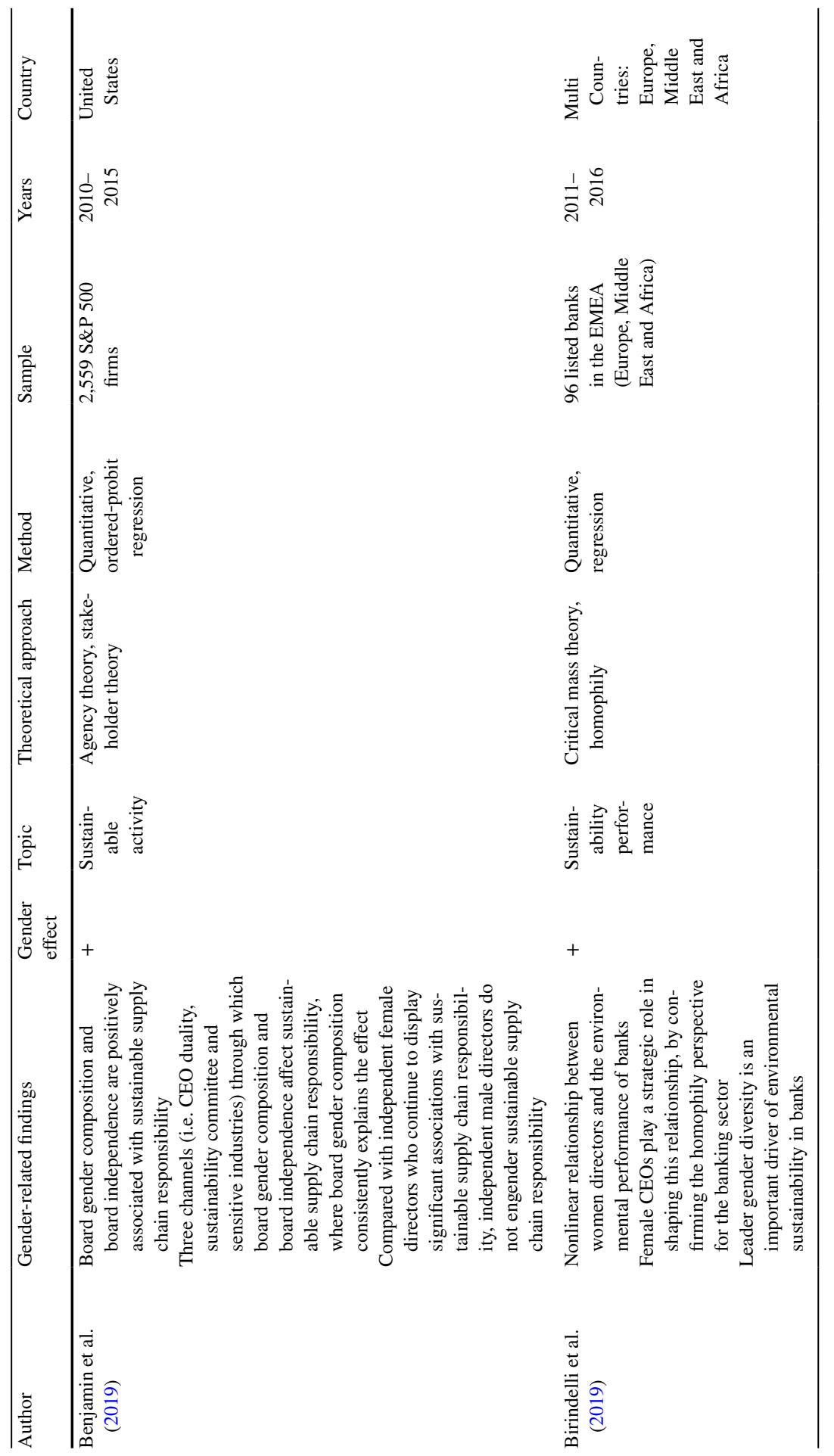




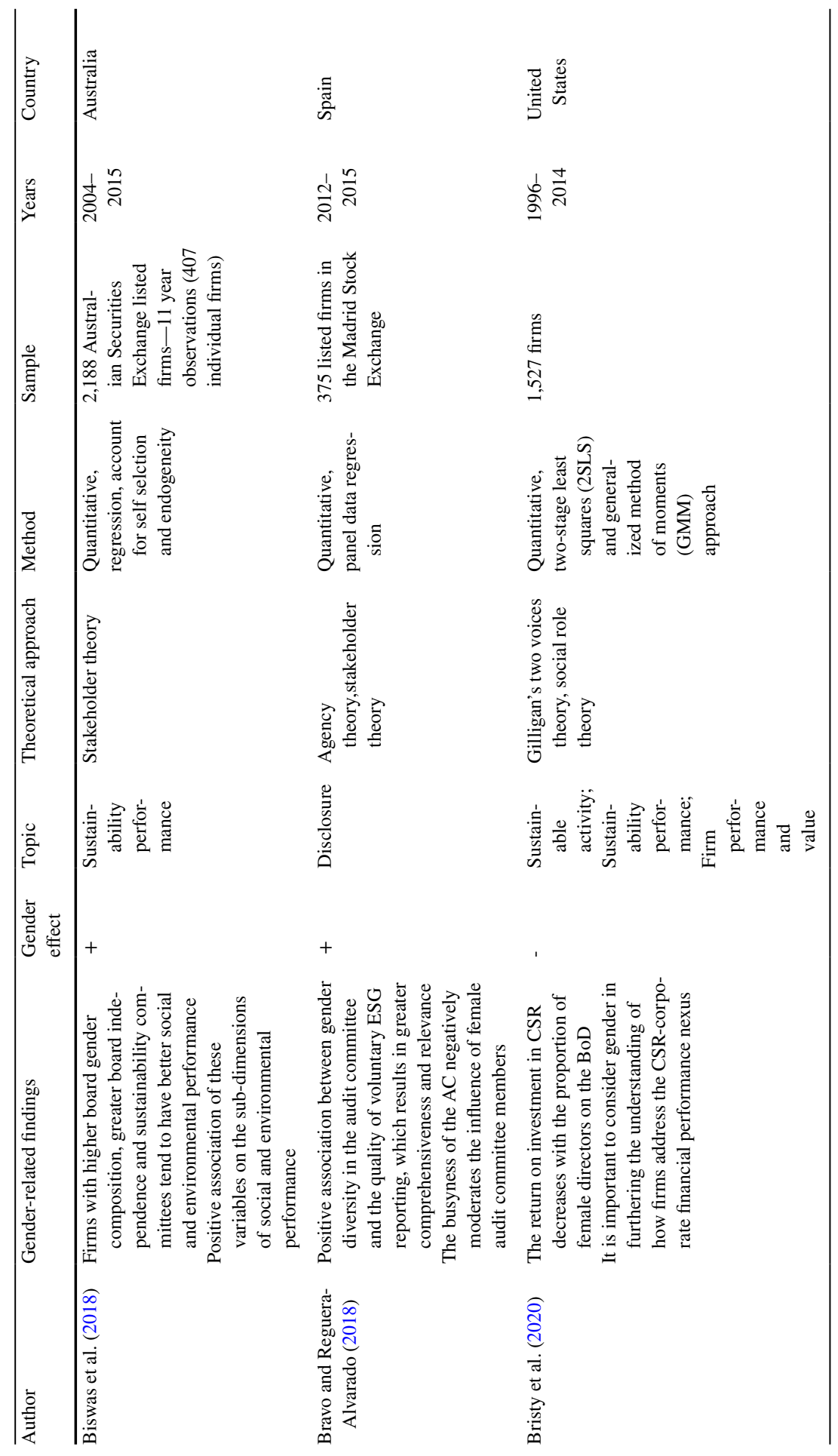




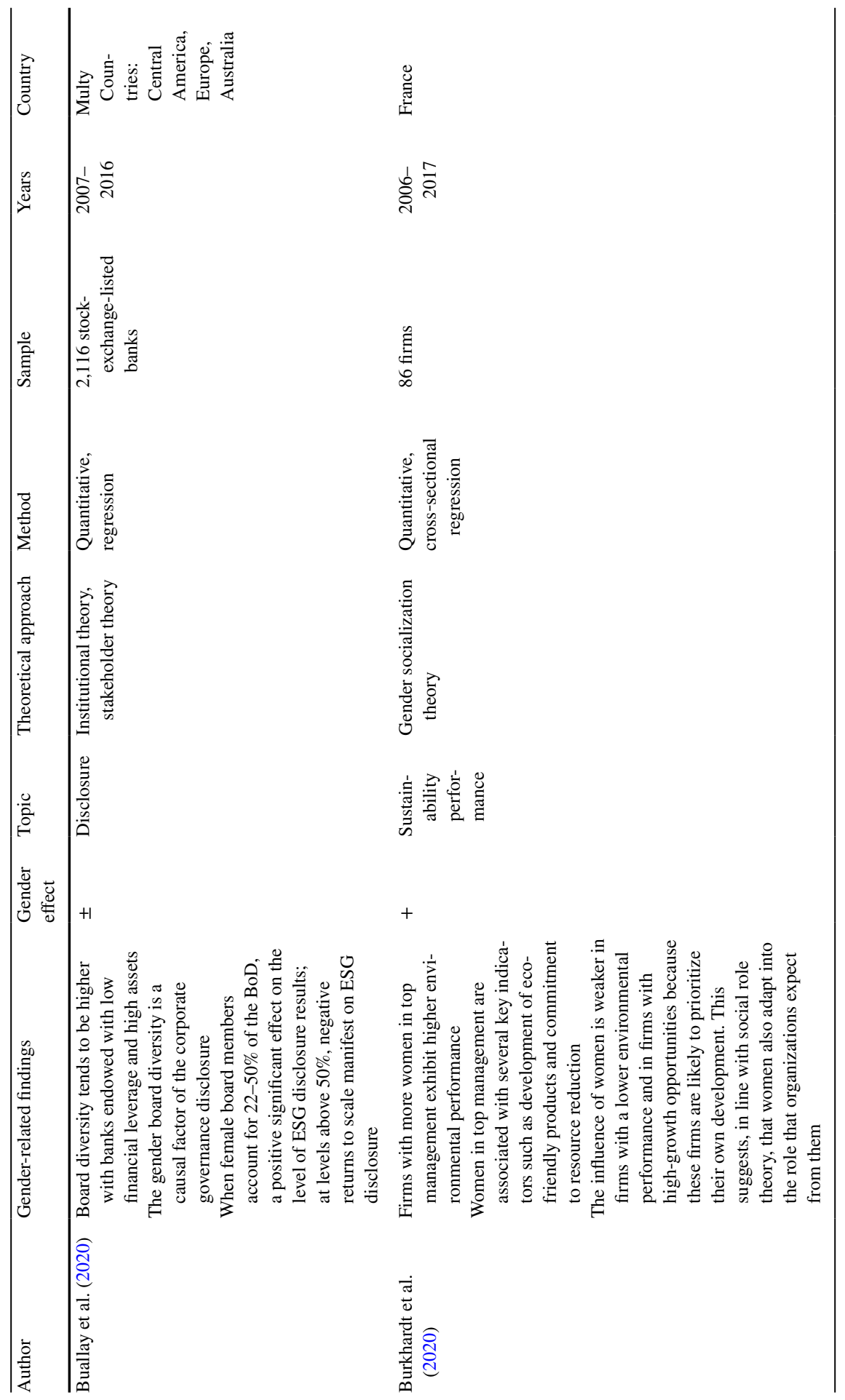




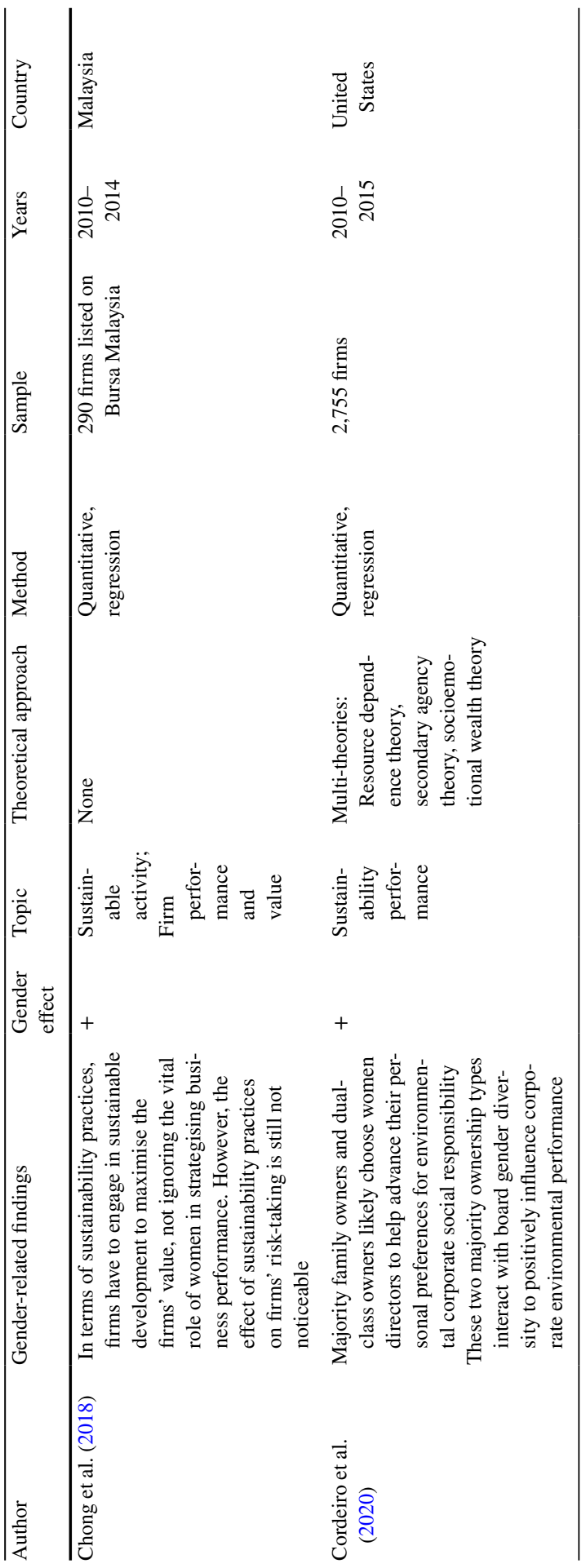




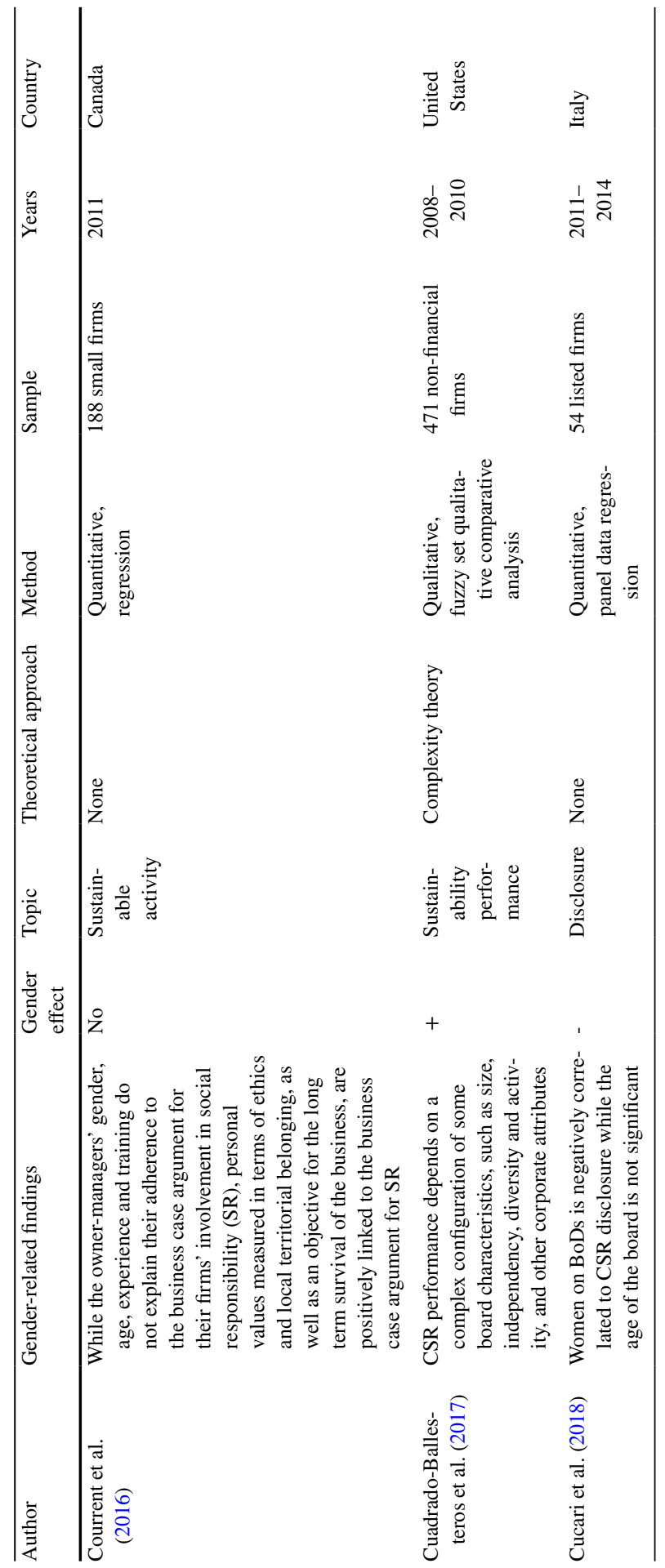




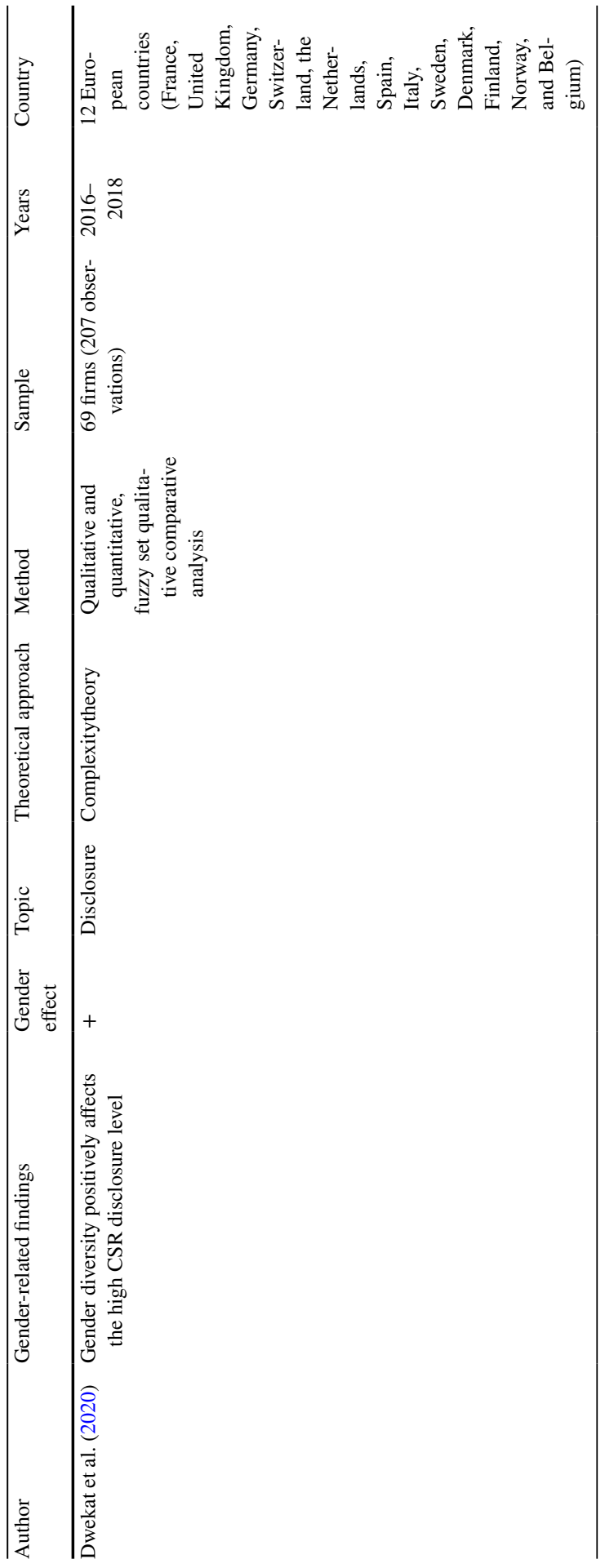




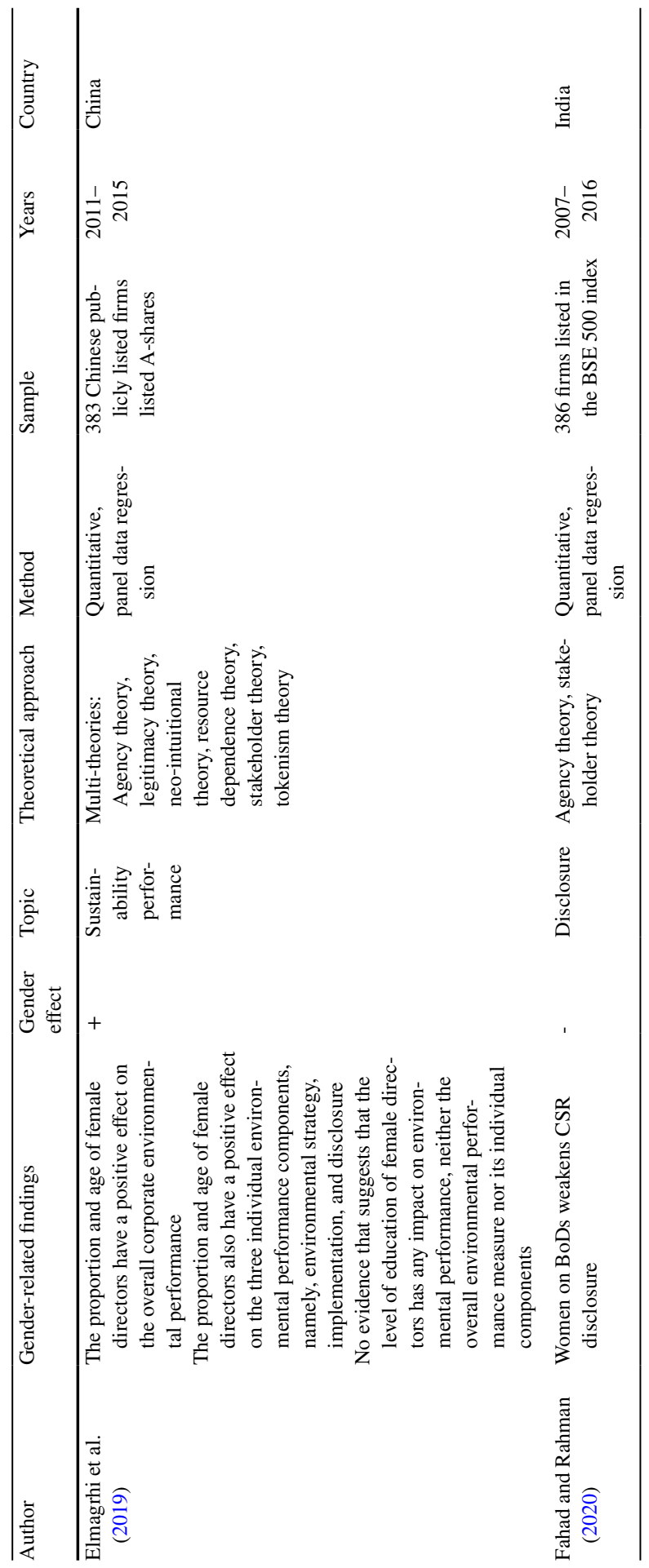




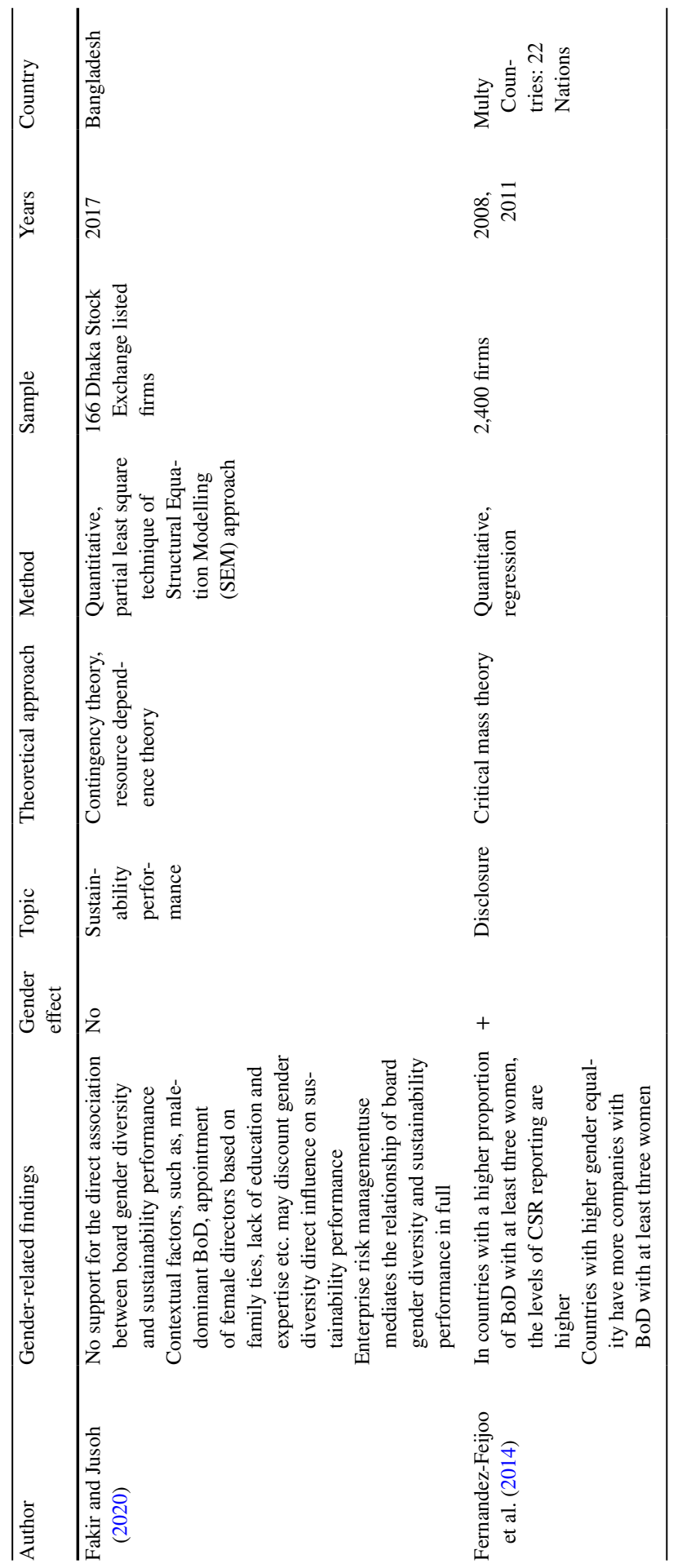




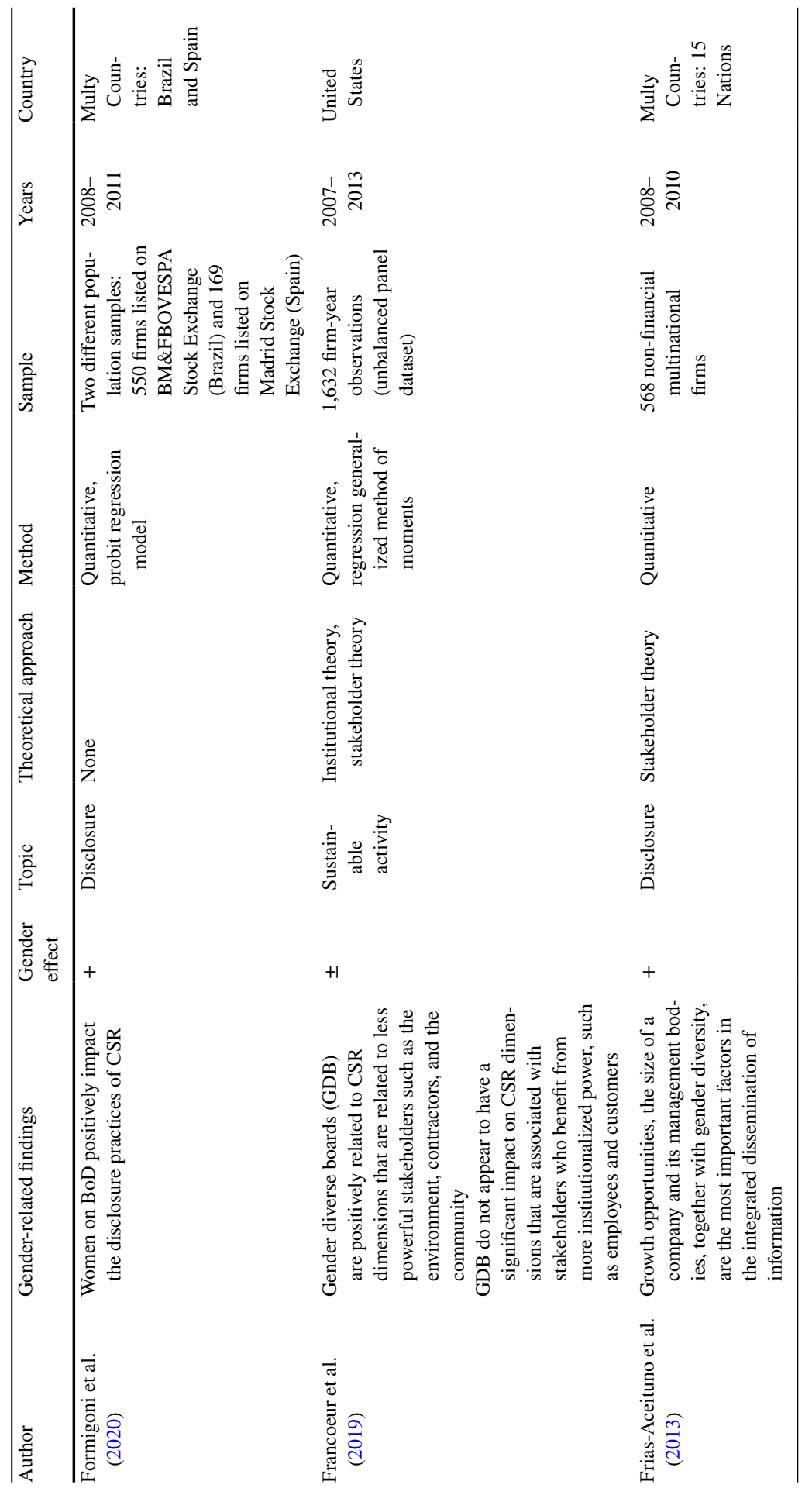




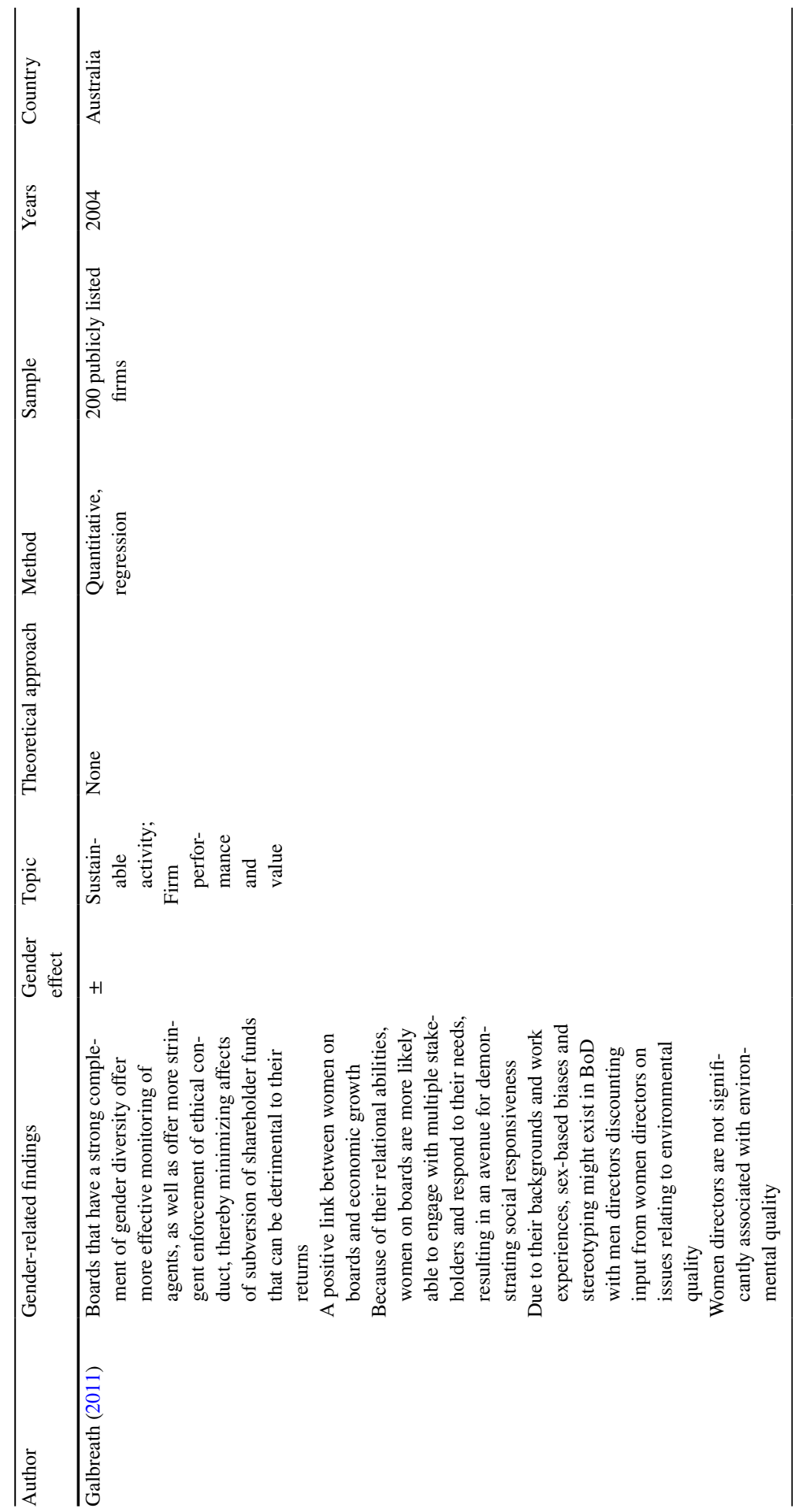




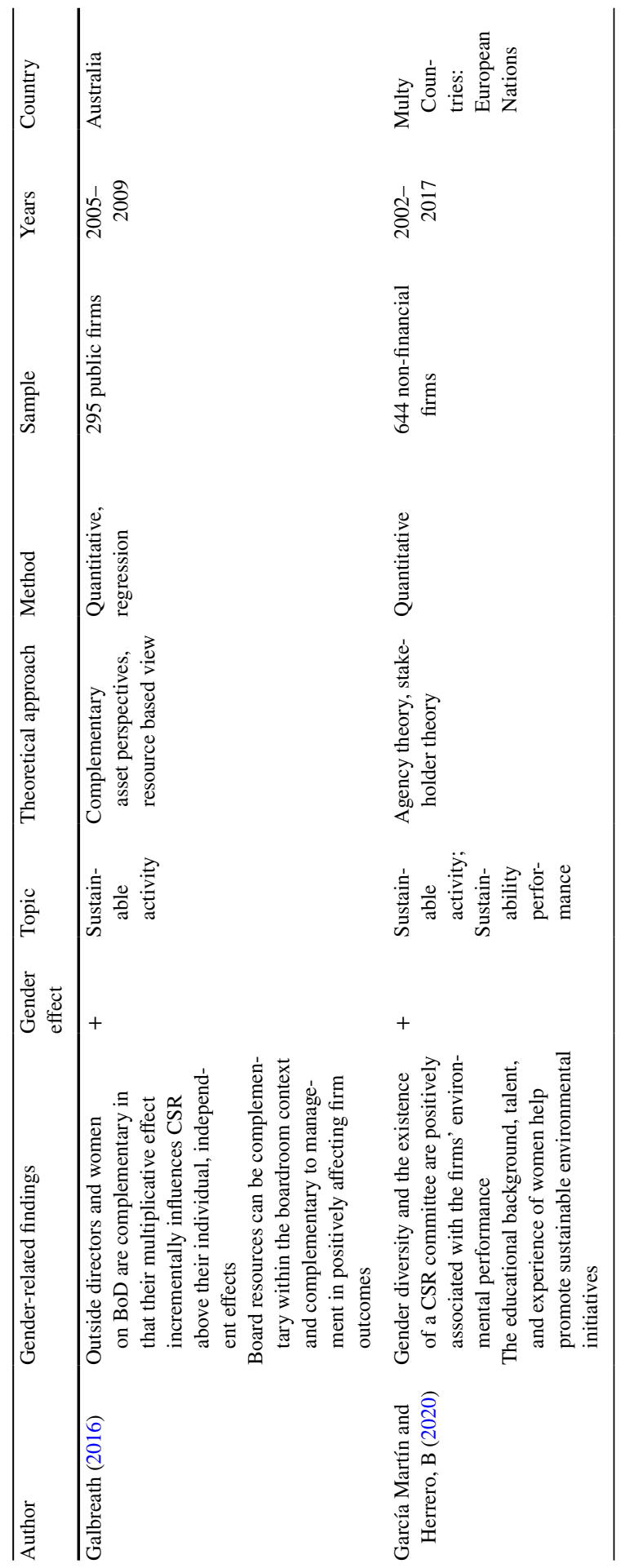




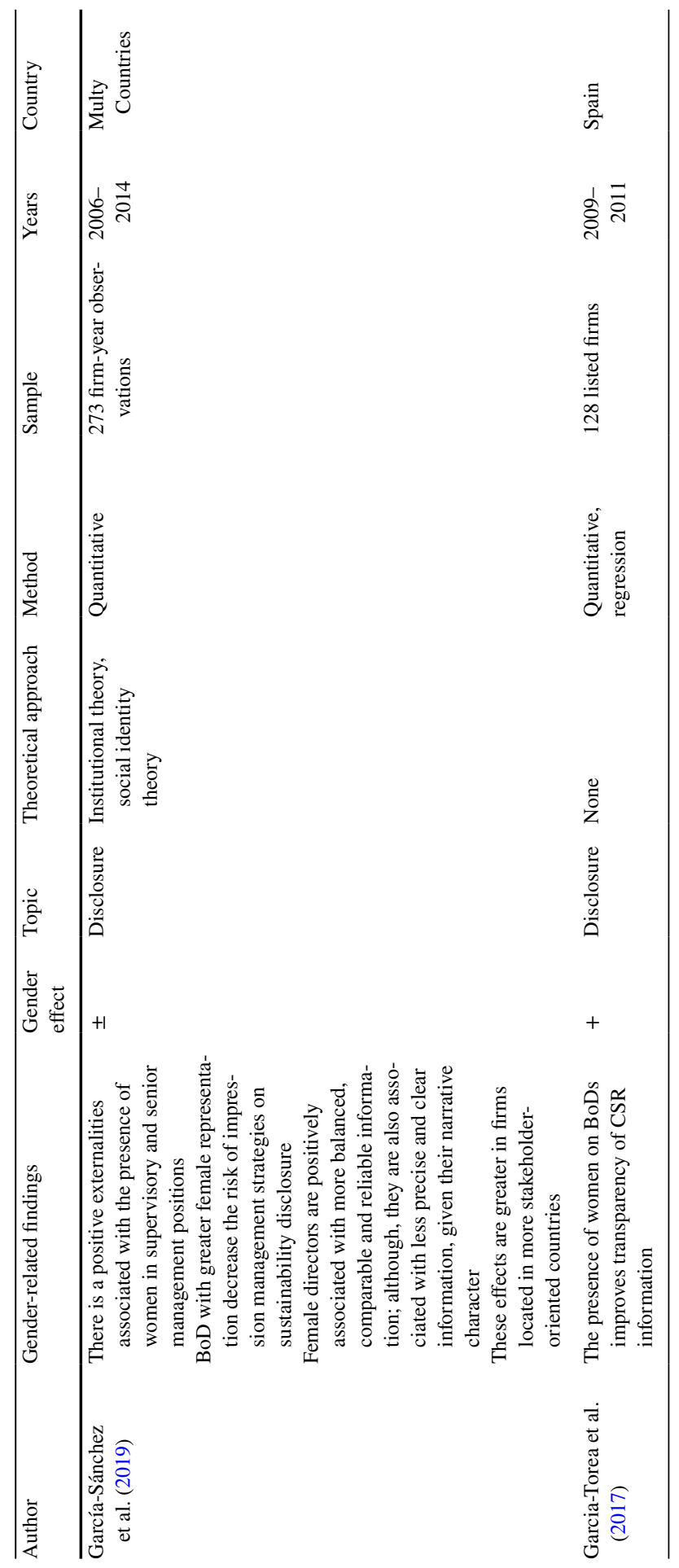




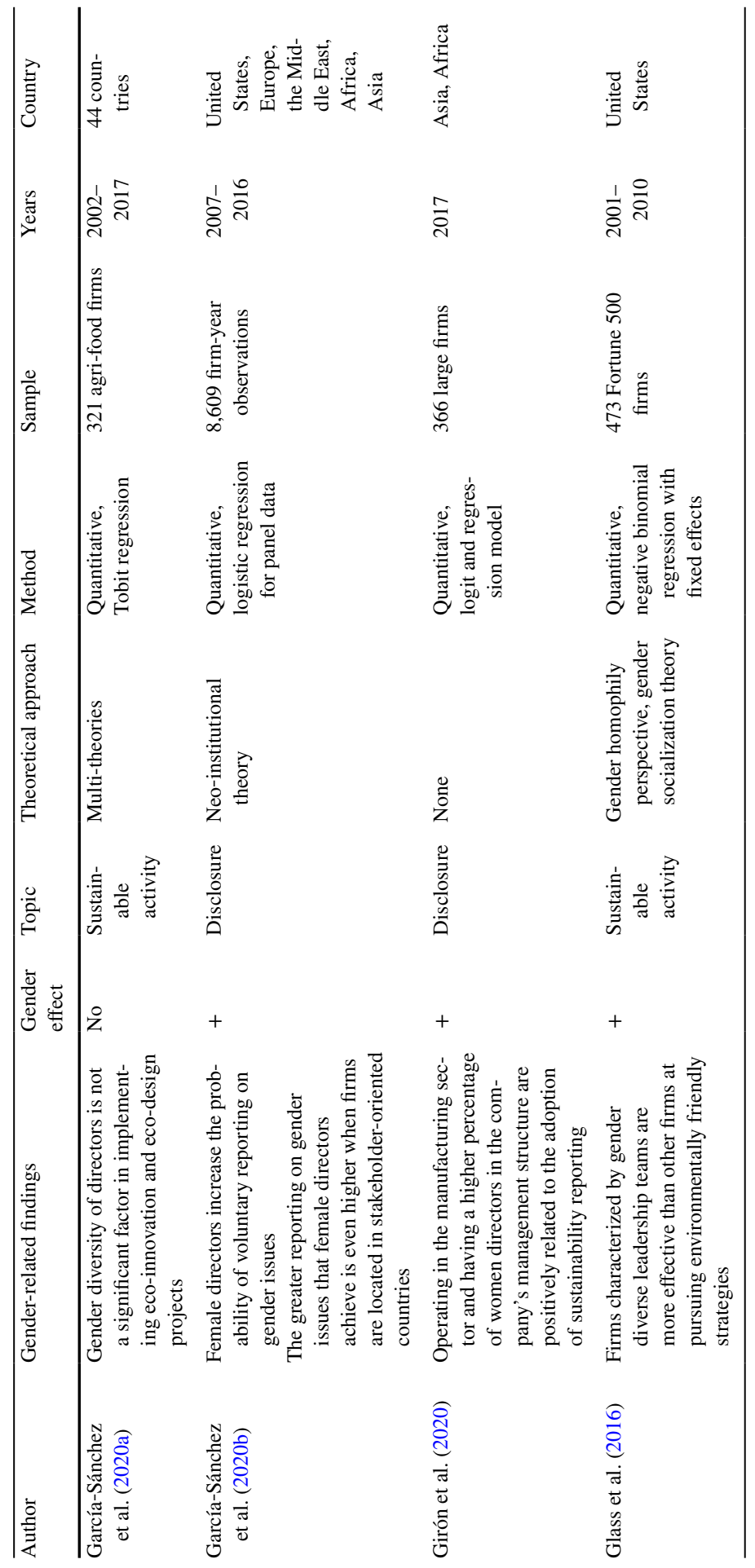




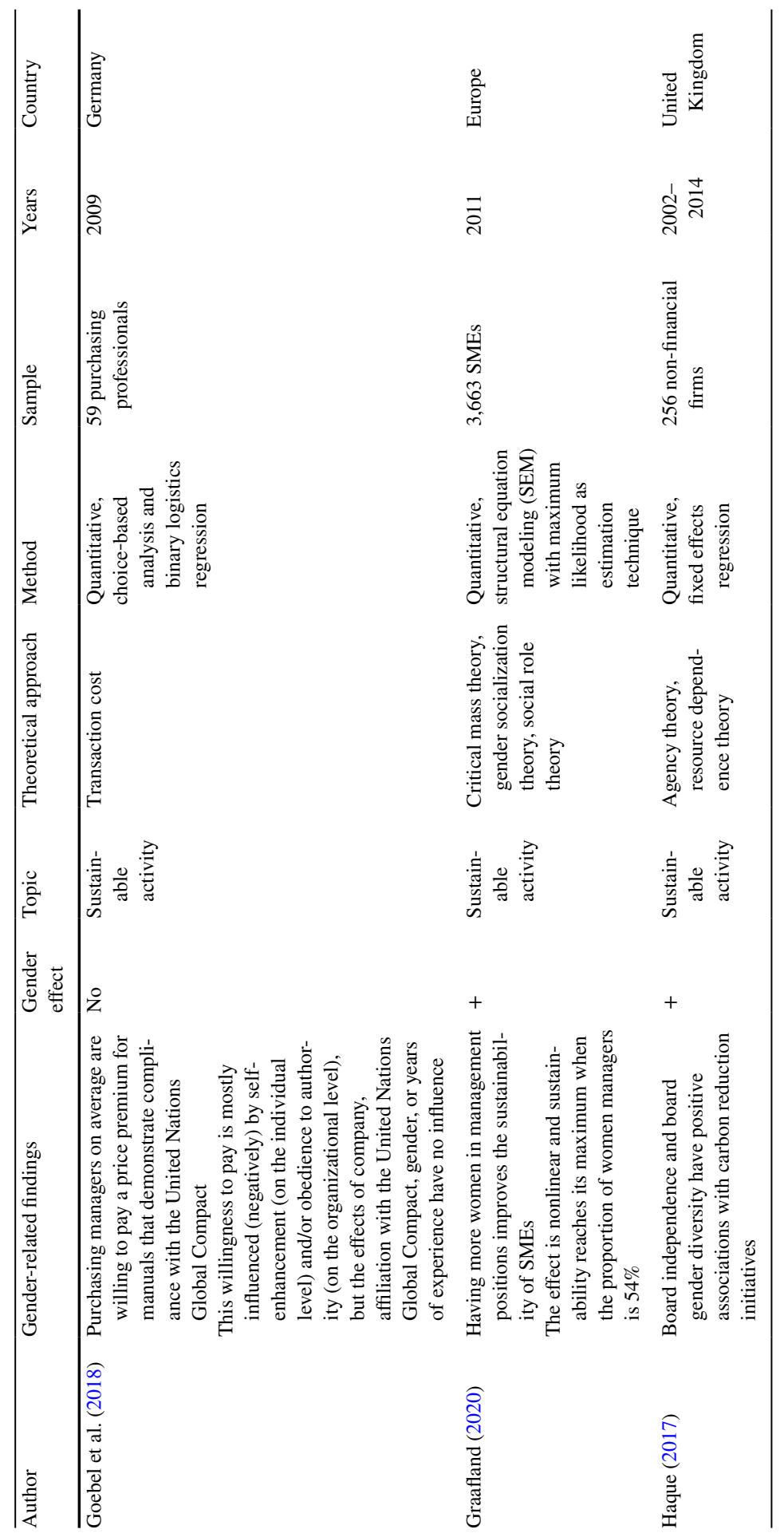




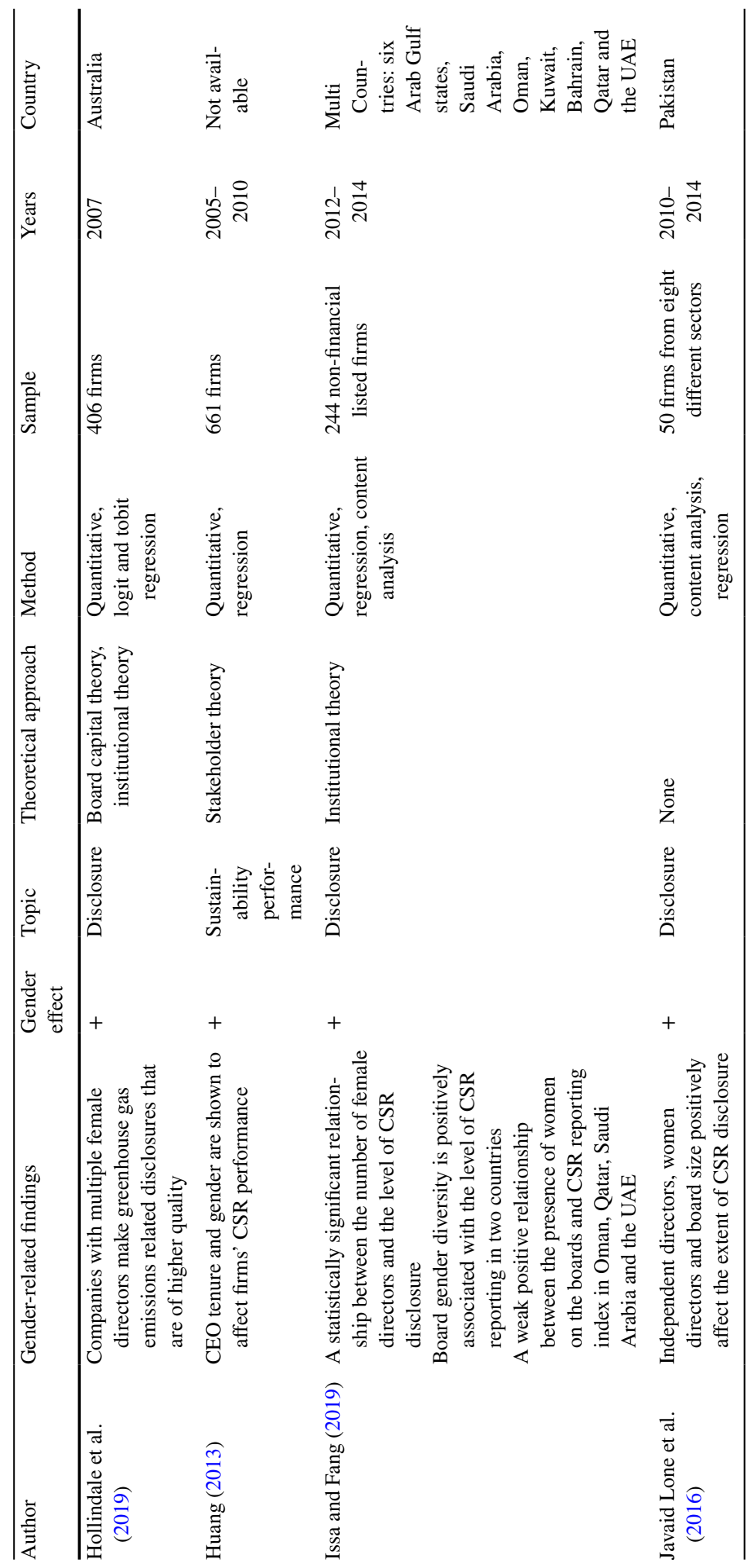




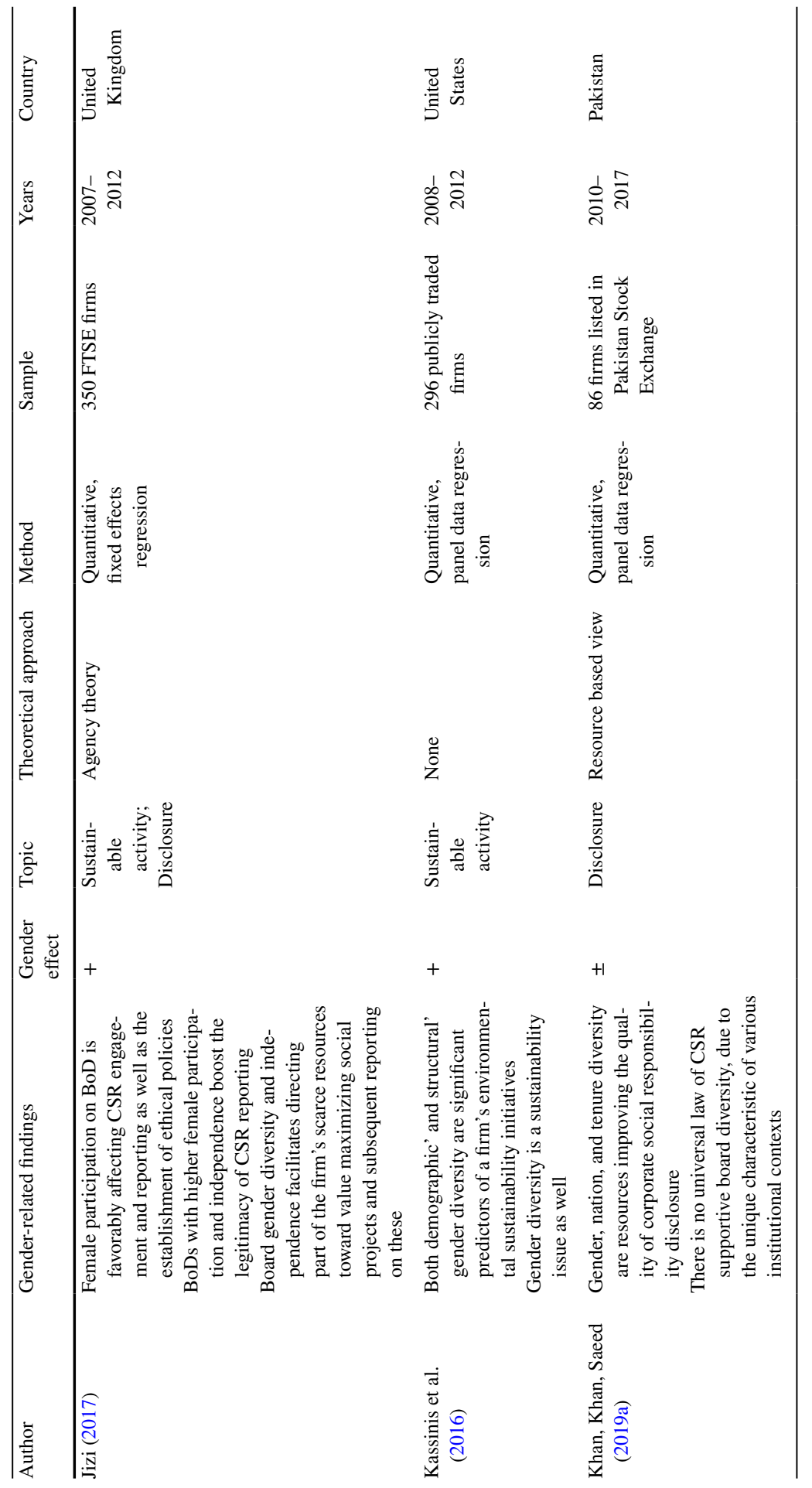




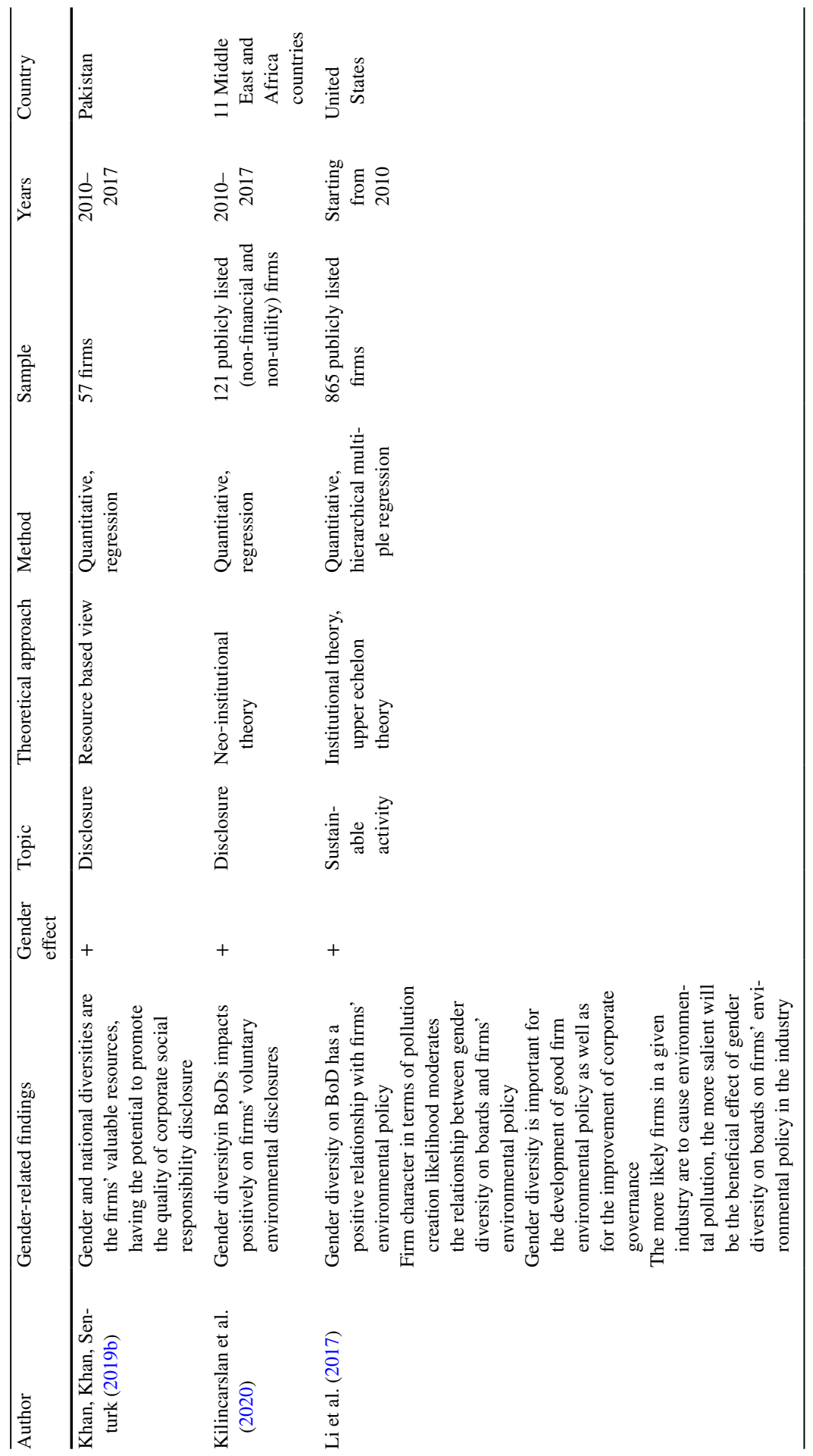




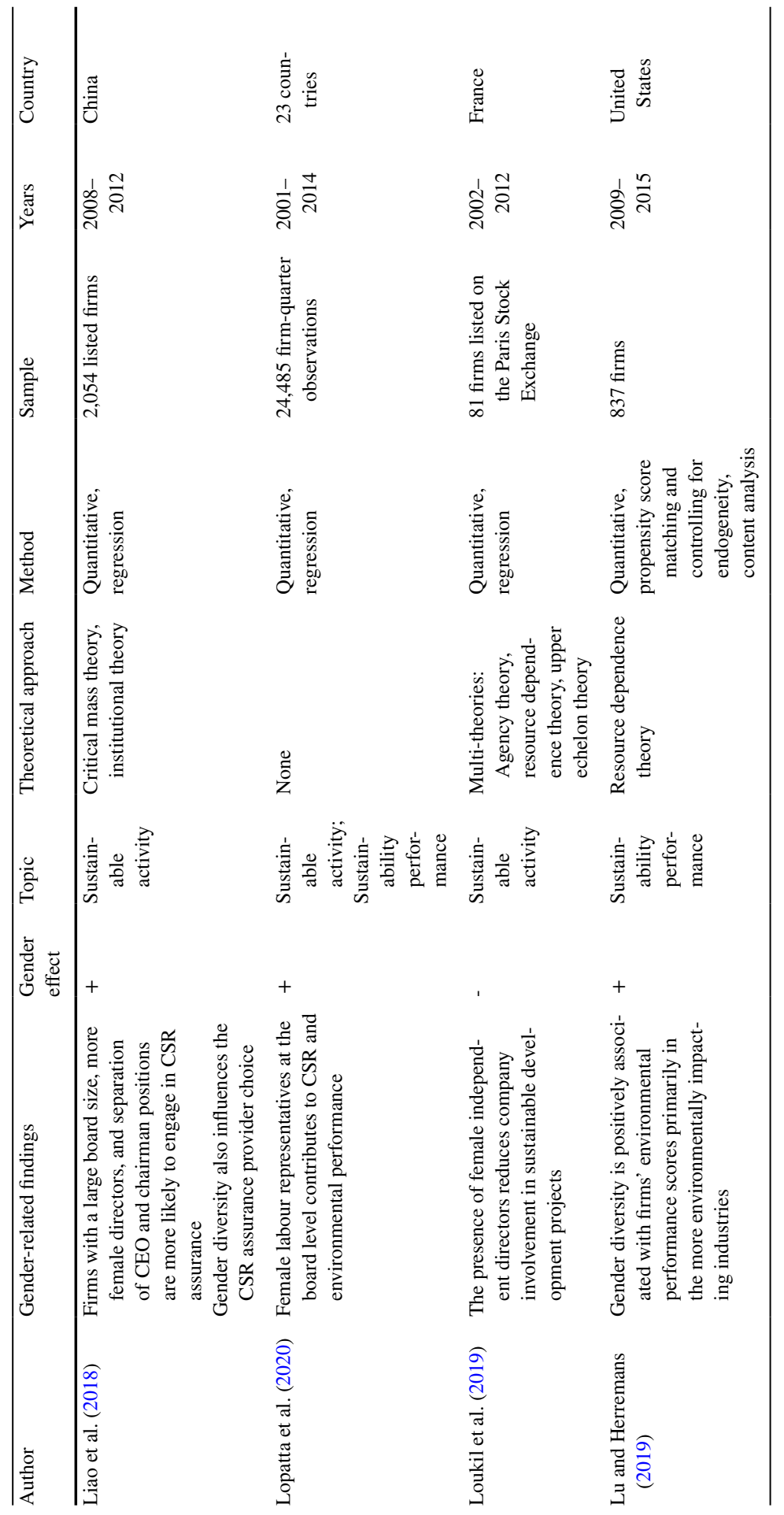




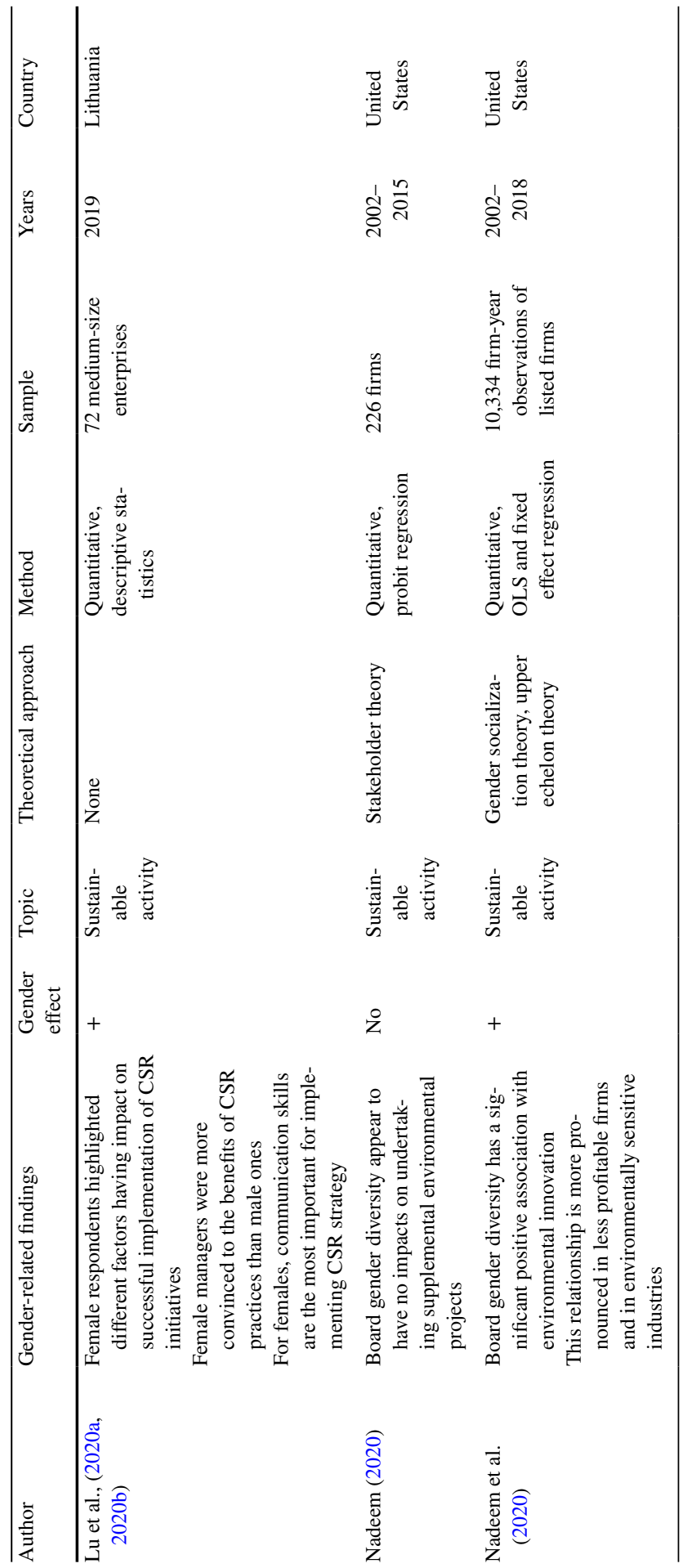




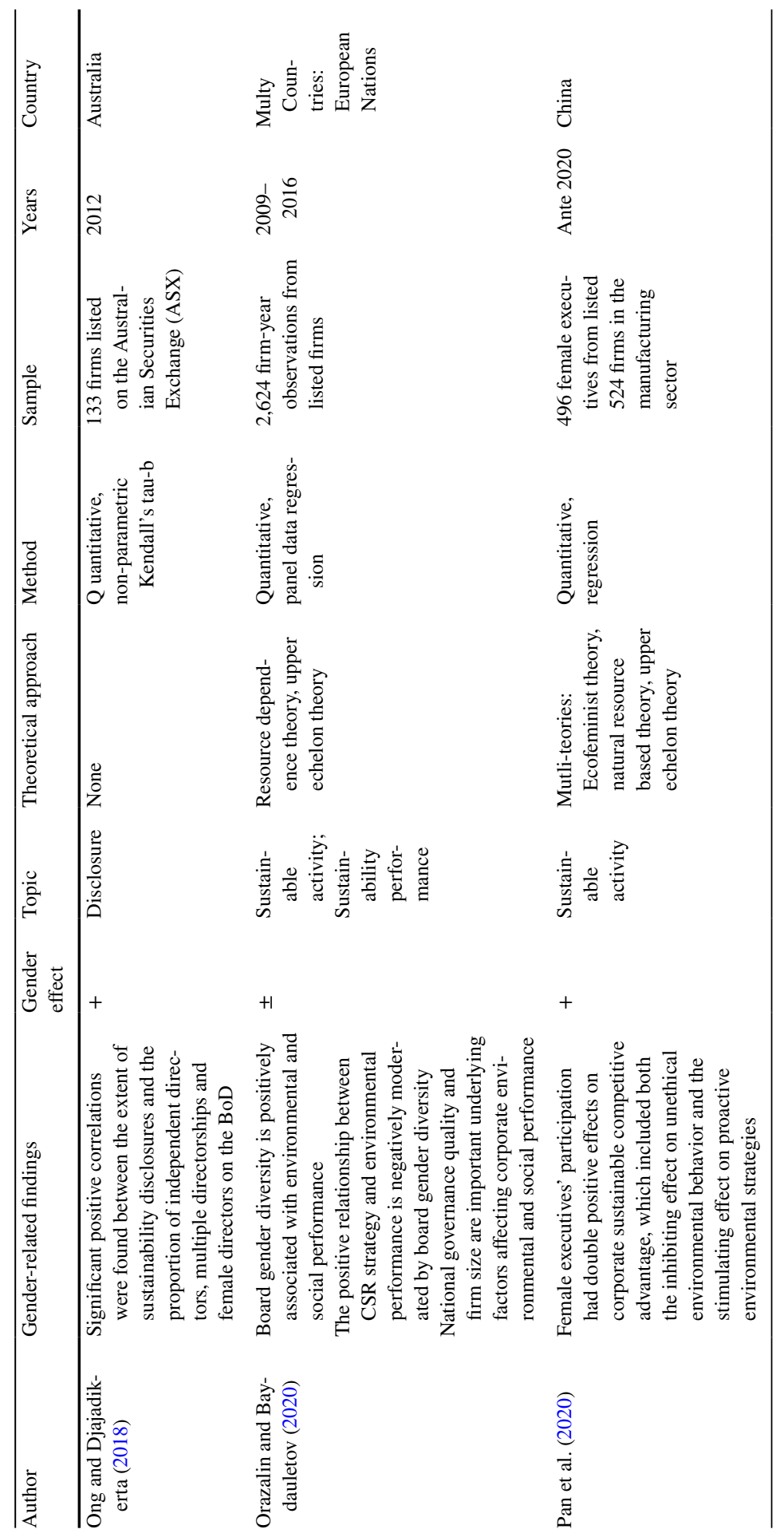




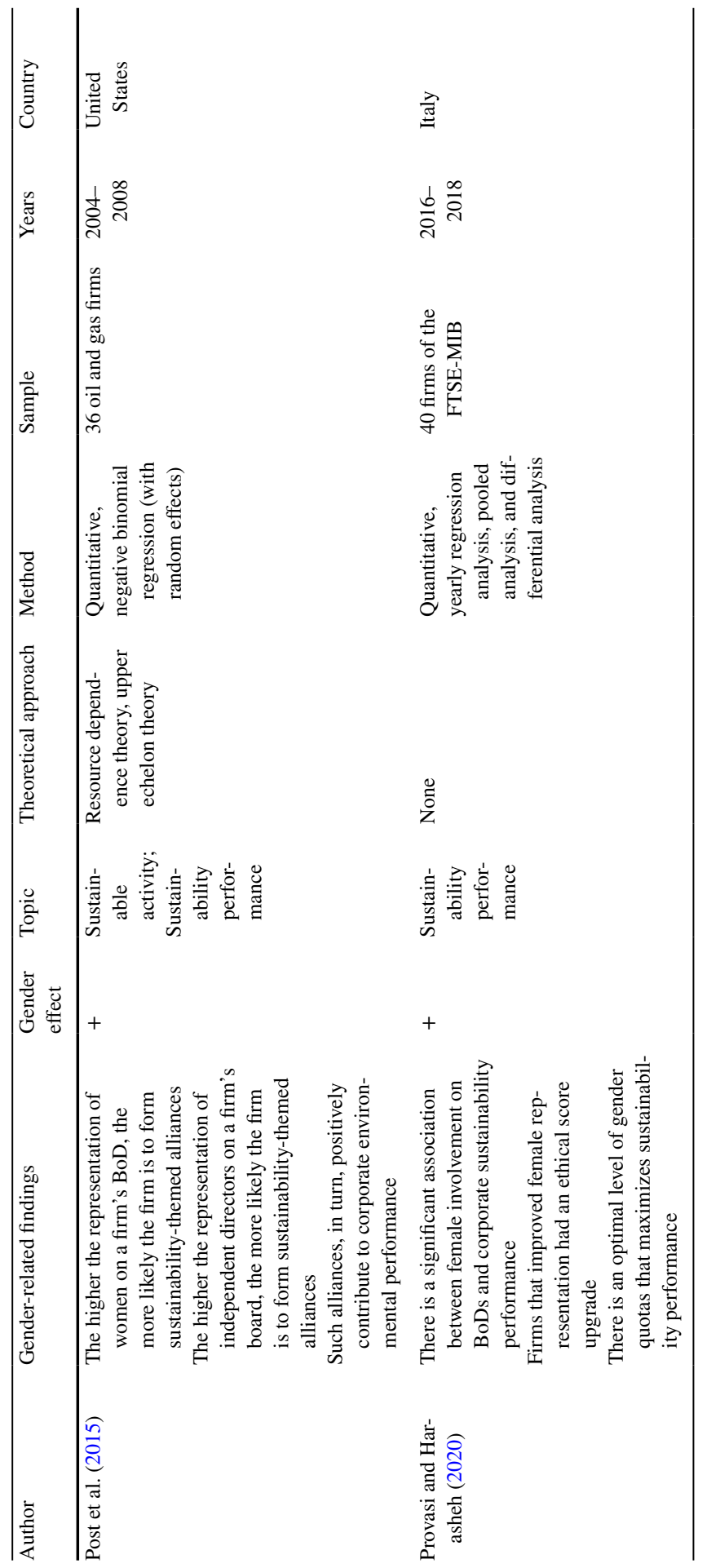




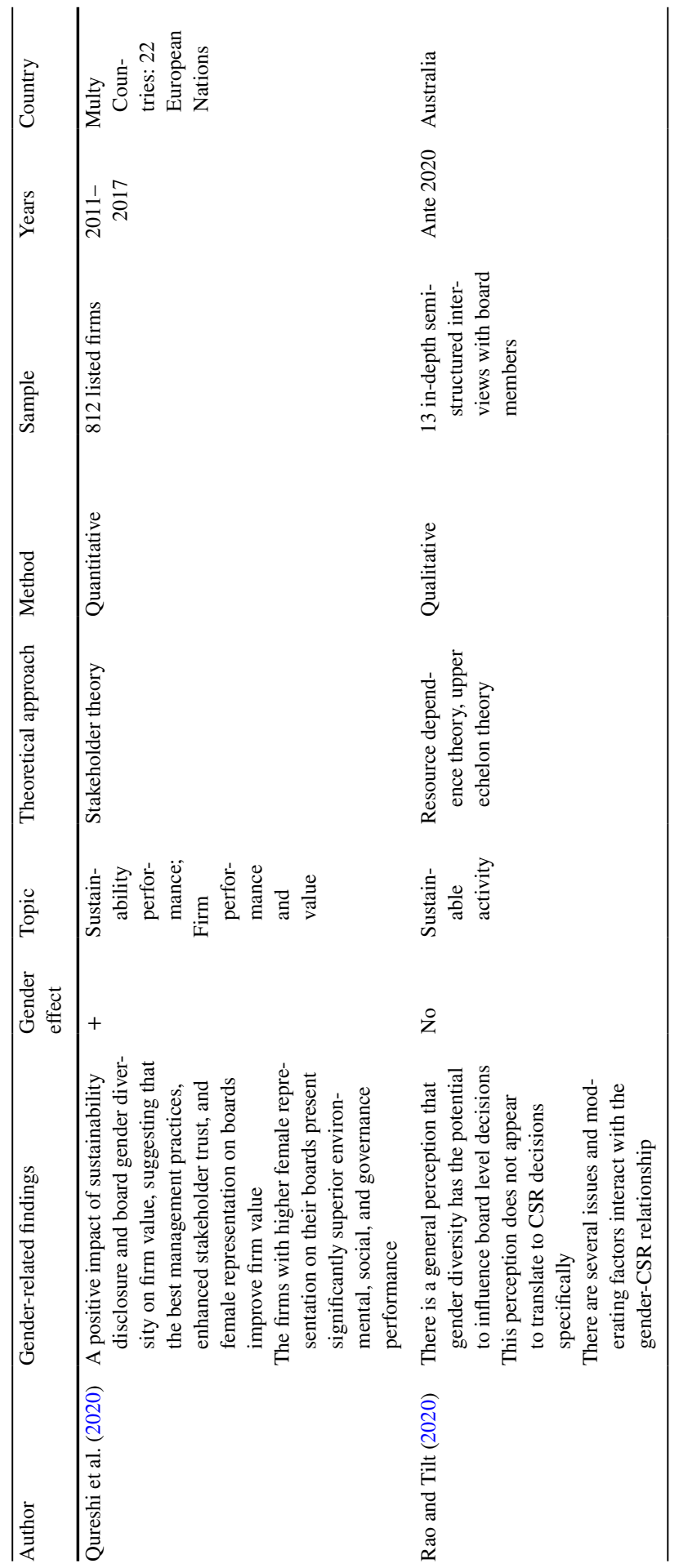




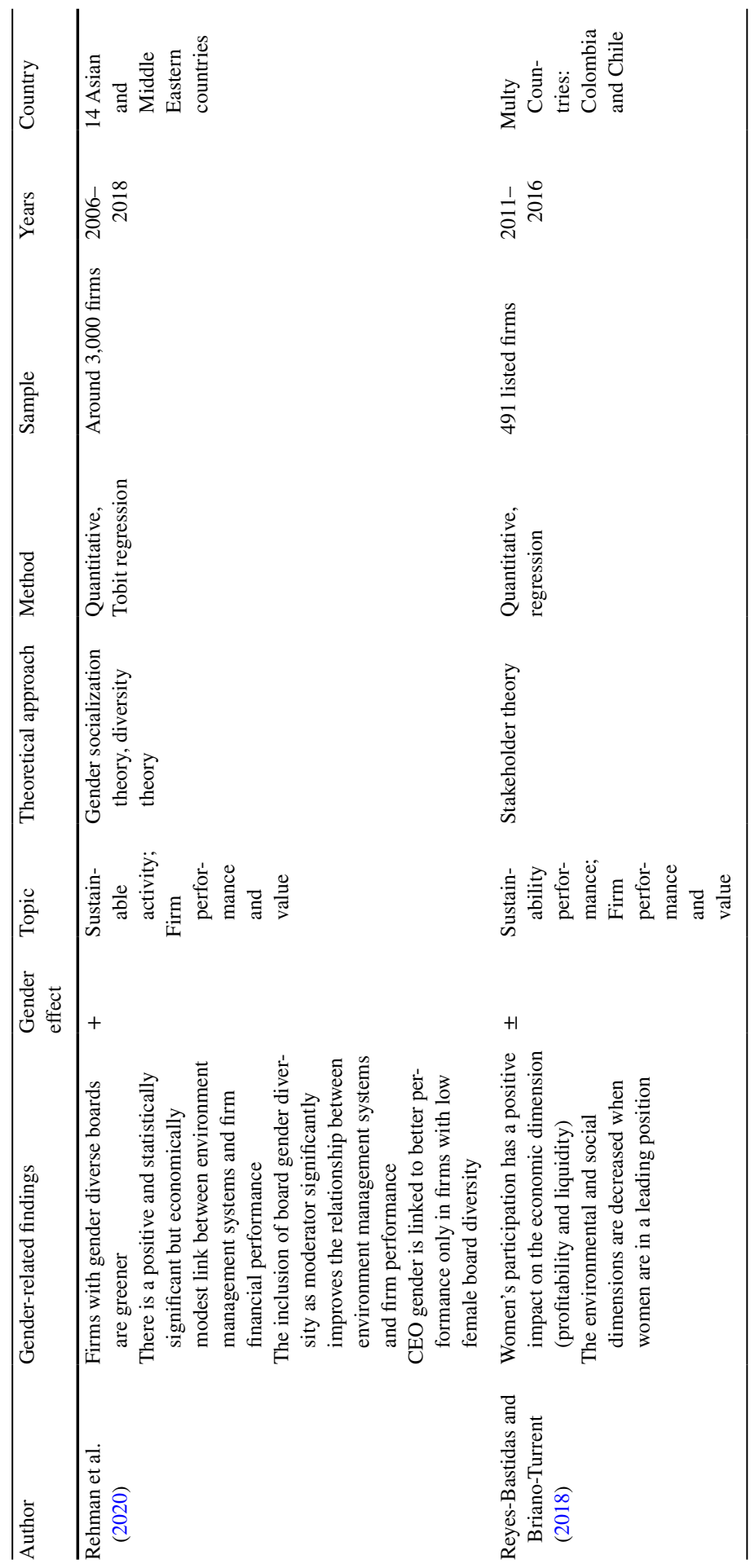




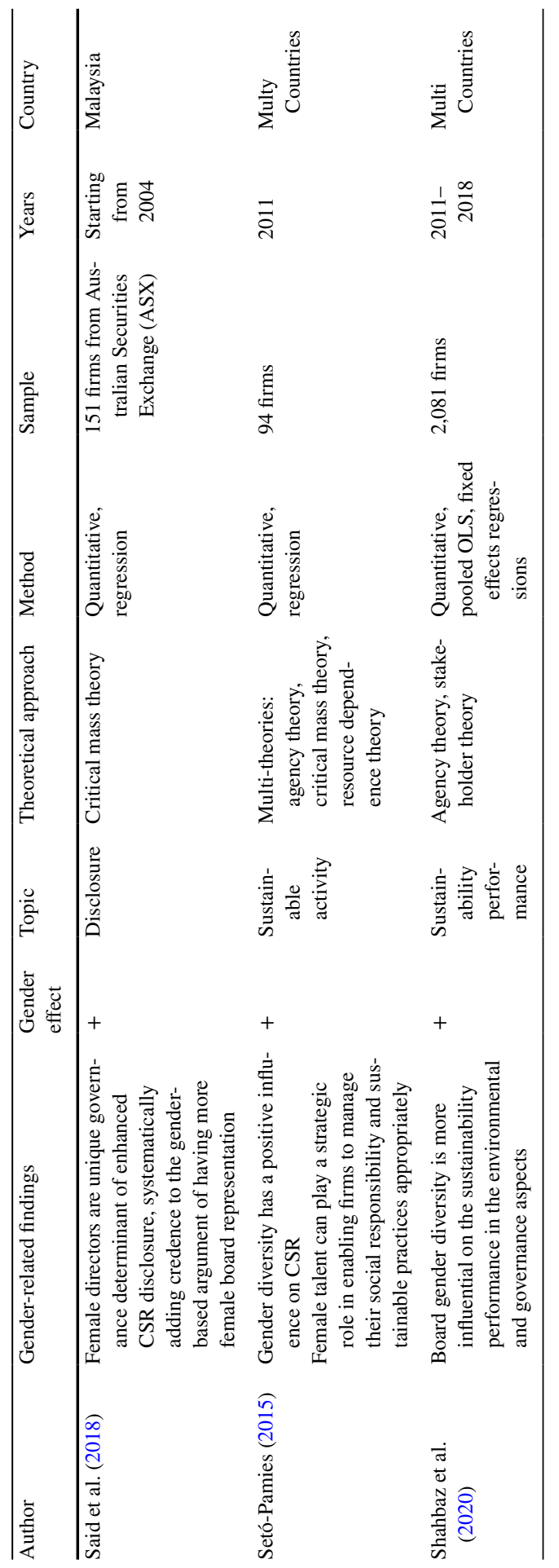




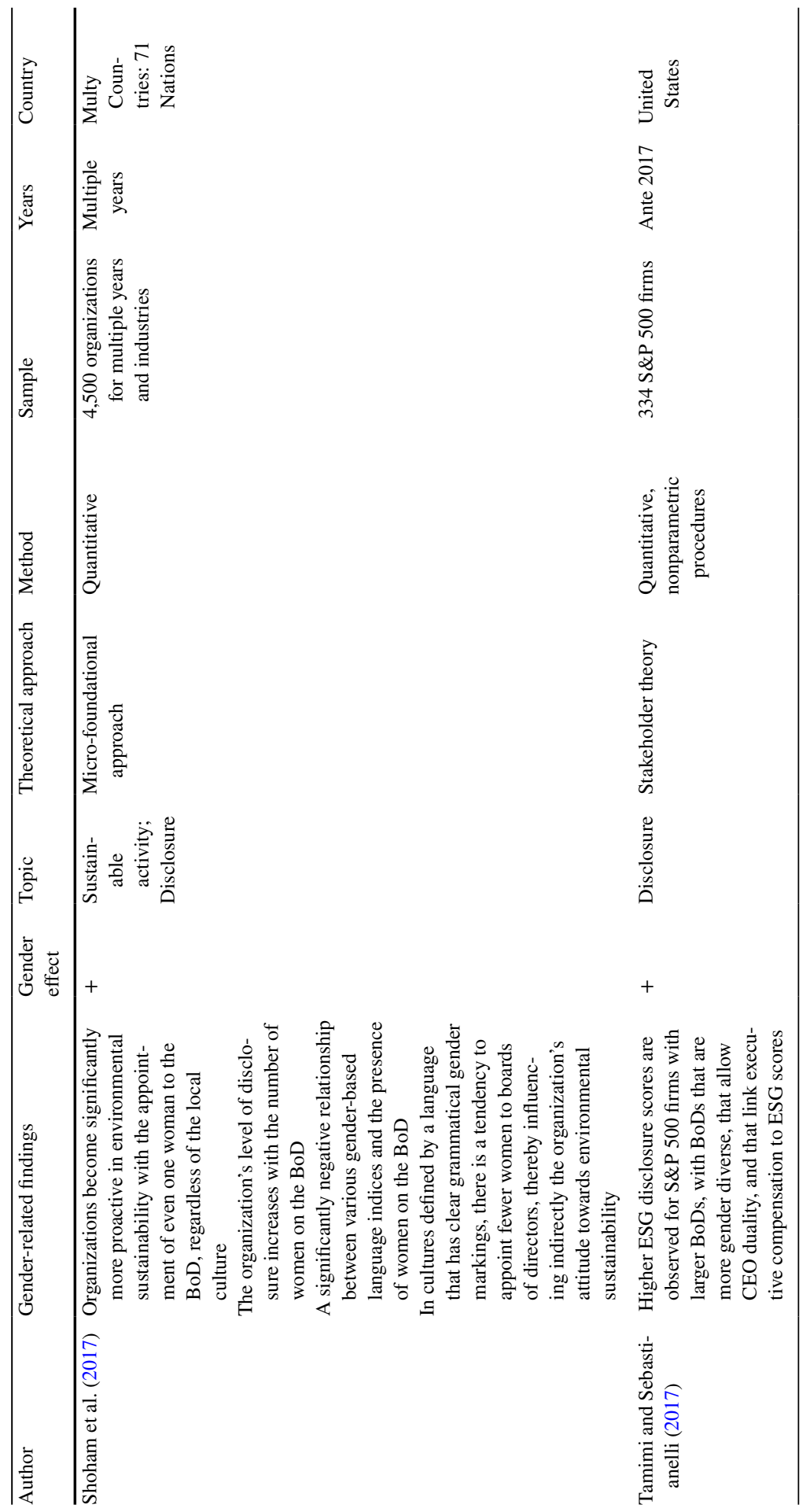




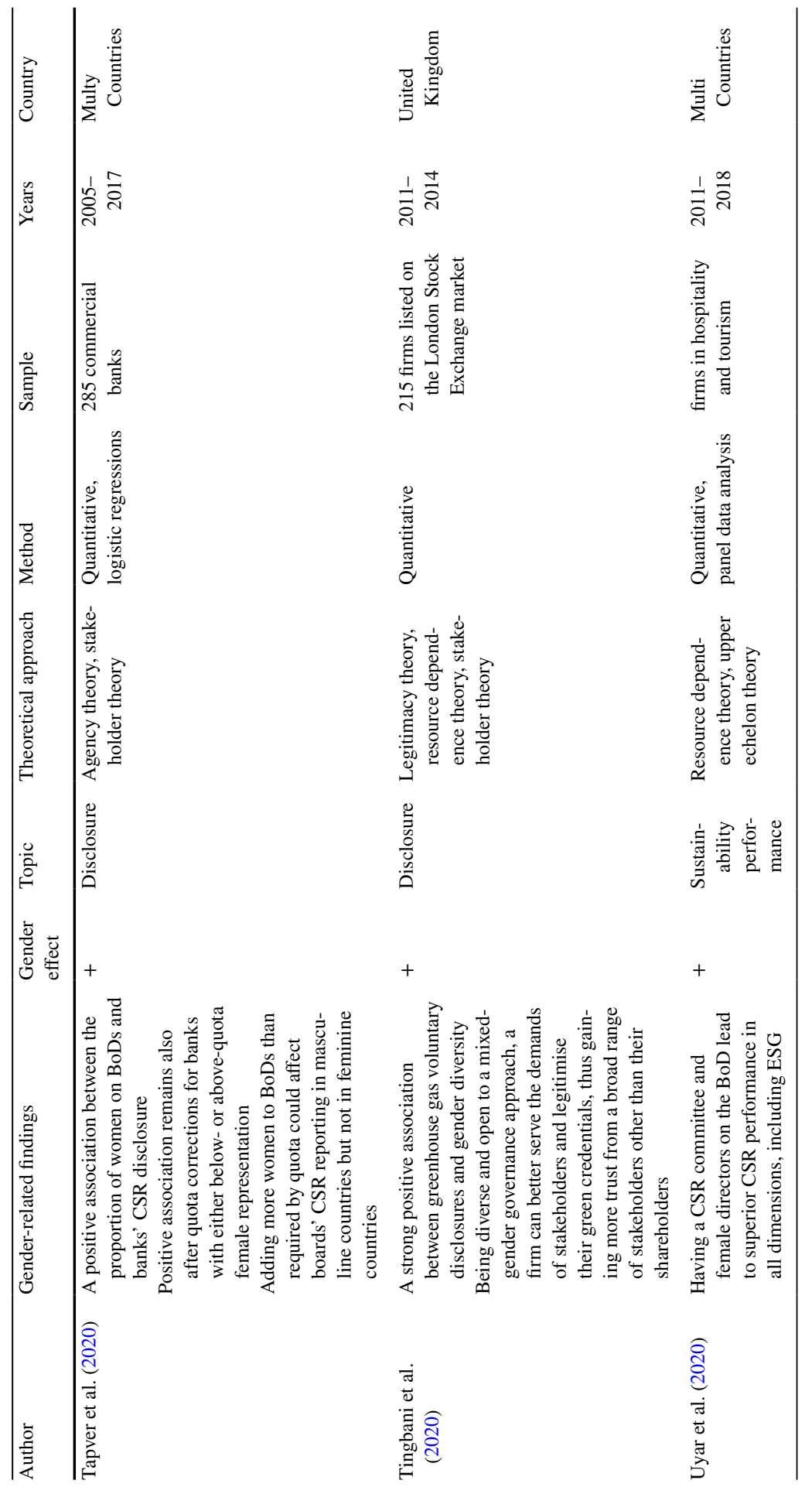




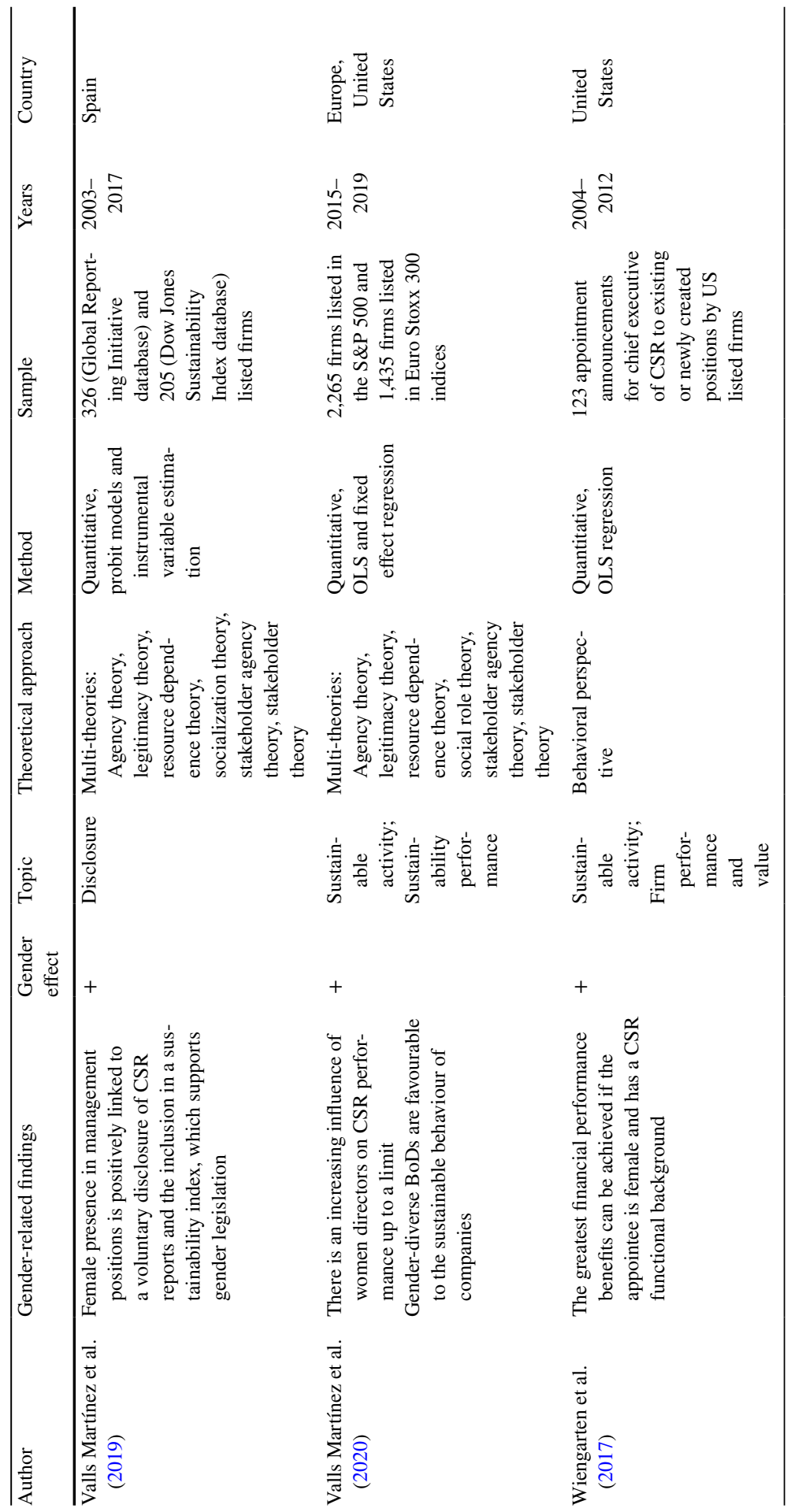




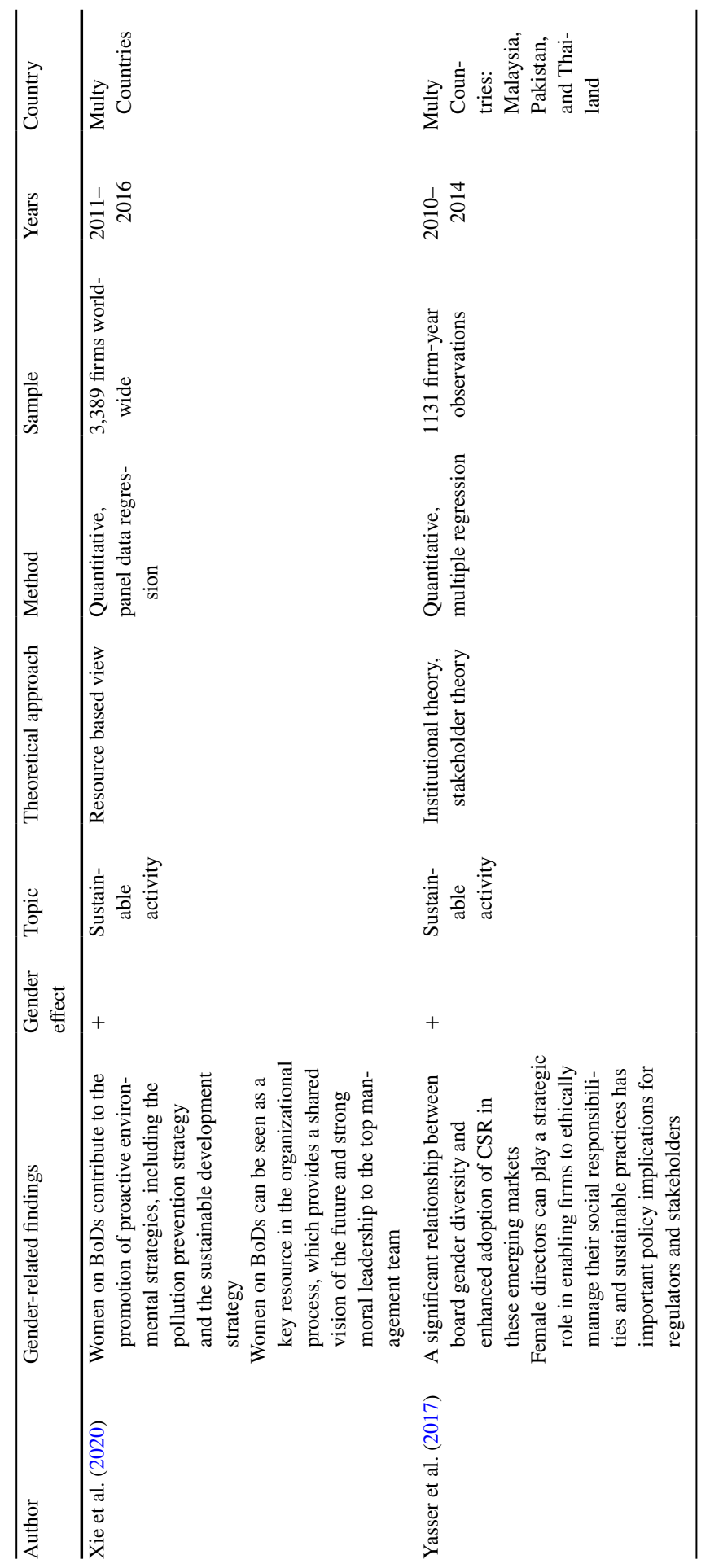


Funding Open access funding provided by Università degli Studi di Brescia within the CRUI-CARE Agreement. University of Brescia, PRD Project DIMI.

\section{Declarations}

Conflict of interest No potential conflict of interest was reported by the author(s).

Open Access This article is licensed under a Creative Commons Attribution 4.0 International License, which permits use, sharing, adaptation, distribution and reproduction in any medium or format, as long as you give appropriate credit to the original author(s) and the source, provide a link to the Creative Commons licence, and indicate if changes were made. The images or other third party material in this article are included in the article's Creative Commons licence, unless indicated otherwise in a credit line to the material. If material is not included in the article's Creative Commons licence and your intended use is not permitted by statutory regulation or exceeds the permitted use, you will need to obtain permission directly from the copyright holder. To view a copy of this licence, visit http://creativecommons.org/licen ses/by/4.0/.

\section{References}

Ajaz, A., Shenbei, Z., \& Sarfraz, M. (2020). Delineating the influence of boardroom gender diversity on corporate social responsibility, financial performance and reputation. Logforum, 16(1), 61-74. https://doi.org/10.17270/J.LOG.2019.376

Akhmetshin, E., Danchikov, E., Polyanskaya, T., Plaskova, N., Prodanova, N., \& Zhiltsov, S. (2018). Analysis of innovation activity of enterprises in modern business environment. Journal of Advanced Research in Law and Economics, 8(8), 2311. https://doi.org/10.14505/jarle.v8.8(30).01

Al Fadli, A., Sands, J., Jones, G., Beattie, C., \& Pensiero, D. (2019). Board gender diversity and CSR reporting: Evidence from Jordan. Australasian Accounting, Business and Finance Journal, 13(3), 29-52. https://doi.org/10.14453/aabfj.v13i3.3

Alazzani, A., Hassanein, A., \& Aljanadi, Y. (2017). Impact of gender diversity on social and environmental performance: Evidence from Malaysia. Corporate Governance: The International Journal of Business in Society, 17(2), 266-283. https://doi.org/10.1108/CG-12-2015-0161

Alazzani, A., Wan-Hussin, W. N., \& Jones, M. (2019). Muslim CEO, women on boards and corporate responsibility reporting: Some evidence from Malaysia. Journal of Islamic Accounting and Business Research, 10(2), 274-296. https://doi.org/10.1108/JIABR-01-2017-0002

Alia, M. J. A., \& Mardawi, Z. M. (2021). The impact of ownership structure and board characteristics on corporate social responsibility disclosed by palestinian companies. Jordan Journal of Business Administration, 17(2), 254-277.

Al-Shaer, H., \& Zaman, M. (2016). Board gender diversity and sustainability reporting quality. Journal of Contemporary Accounting \& Economics, 12(3), 210-222. https://doi.org/10.1016/j.jcae.2016. 09.001

Amorelli, M., \& García-Sánchez, I. (2020a). Critical mass of female directors, human capital, and stakeholder engagement by corporate social reporting. Corporate Social Responsibility and Environmental Management, 27(1), 204-221. https://doi.org/10.1002/csr.1793

Amorelli, M., \& García-Sánchez, I. (2020b). Trends in the dynamic evolution of board gender diversity and corporate social responsibility. Corporate Social Responsibility and Environmental Management. https://doi.org/10.1002/csr.2079

Anazonwu, H. O., Egbunike, F. C., \& Gunardi, A. (2018). Corporate board diversity and sustainability reporting: A study of selected listed manufacturing firms in Nigeria. Indonesian Journal of Sustainability Accounting and Management. https://doi.org/10.28992/ijsam.v2i1.52

Appuhami, R., \& Tashakor, S. (2017). The impact of audit committee characteristics on CSR disclosure: An analysis of Australian firms. Australian Accounting Review, 27(4), 400-420. https://doi.org/10. 1111/auar. 12170

Ararat, M., \& Sayedy, B. (2019). Gender and climate change disclosure: An Interdimensional policy approach. Sustainability, 11(24), 7217. https://doi.org/10.3390/su11247217 
Arayssi, M., Dah, M., \& Jizi, M. (2016). Women on boards, sustainability reporting and firm performance. Sustainability Accounting, Management and Policy Journal, 7(3), 376-401. https://doi.org/ 10.1108/SAMPJ-07-2015-0055

Arayssi, M., Jizi, M., \& Tabaja, H. H. (2020). The impact of board composition on the level of ESG disclosures in GCC countries. Sustainability Accounting, Management and Policy Journal, 11(1), 137-161. https://doi.org/10.1108/SAMPJ-05-2018-0136

Ardito, L., Dangelico, R. M., \& Messeni Petruzzelli, A. (2020). The link between female representation in the boards of directors and corporate social responsibility: Evidence from B corps. Corporate Social Responsibility and Environmental Management. https://doi.org/10.1002/csr.2082

Argento, D., Grossi, G., Persson, K., \& Vingren, T. (2019). Sustainability disclosures of hybrid organizations: Swedish state-owned enterprises. Meditari Accountancy Research, 27(4), 505-533. https:// doi.org/10.1108/MEDAR-07-2018-0362

Arredondo Trapero, F. G., Velázquez Sánchez, L. M., \& de la Garza García, J. (2013). Políticas de diversidad y flexibilidad laboral en el marco de la responsabilidad social empresarial. Un análisis desde la perspectiva de género [Diversity and labor flexibility policies in the context of corporate social responsibility. An analysis from a gender perspective]. Estudios Gerenciales, 29(127), 161-166. https://doi.org/10.1016/j.estger.2013.05.004

Atif, M., Alam, Md. S., \& Hossain, M. (2020). Firm sustainable investment: Are female directors greener? Business Strategy and the Environment, 29(8), 3449-3469. https://doi.org/10.1002/bse. 2588

Atif, M., Hossain, M., Alam, M. S., \& Goergen, M. (2021). Does board gender diversity affect renewable energy consumption? Journal of Corporate Finance, 66, 101665. https://doi.org/10.1016/j.jcorpfin. 2020.101665

Baalouch, F., Ayadi, S. D., \& Hussainey, K. (2019). A study of the determinants of environmental disclosure quality: Evidence from French listed companies. Journal of Management and Governance, 23(4), 939-971. https://doi.org/10.1007/s10997-019-09474-0

Baumgartner, R. J., \& Ebner, D. (2010). Corporate sustainability strategies: Sustainability profiles and maturity levels. Sustainable Development, 18(2), 76-89. https://doi.org/10.1002/sd.447

Beji, R., Yousfi, O., Loukil, N., \& Omri, A. (2020). Board diversity and corporate social responsibility: Empirical evidence from France. Journal of Business Ethics. https://doi.org/10.1007/ s10551-020-04522-4

Bektur, Ç., \& Arzova, S. B. (2020). The effect of women managers in the board of directors of companies on the integrated reporting: Example of Istanbul Stock Exchange (ISE) Sustainability Index. Journal of Sustainable Finance \& Investment. https://doi.org/10.1080/20430795.2020.1796417

Ben Fatma, H., \& Chouaibi, J. (2021). Corporate governance and CSR disclosure: Evidence from European financial institutions. International Journal of Disclosure and Governance. https://doi.org/10. 1057/s41310-021-00117-1

Ben-Amar, W., Chang, M., \& McIlkenny, P. (2017). Board gender diversity and corporate response to sustainability initiatives: Evidence from the carbon disclosure project. Journal of Business Ethics, 142(2), 369-383. https://doi.org/10.1007/s10551-015-2759-1

Benjamin, S., Mansi, M., \& Pandey, R. (2019). Board gender composition, board independence and sustainable supply chain responsibility. Accounting \& Finance. https://doi.org/10.1111/acfi.12532

Birindelli, G., Dell'Atti, S., Iannuzzi, A., \& Savioli, M. (2018). Composition and activity of the board of directors: Impact on ESG performance in the banking system. Sustainability, 10(12), 4699. https:// doi.org/10.3390/su10124699

Birindelli, G., Iannuzzi, A. P., \& Savioli, M. (2019). The impact of women leaders on environmental performance: Evidence on gender diversity in banks. Corporate Social Responsibility and Environmental Management. https://doi.org/10.1002/csr.1762

Biswas, P. K., Mansi, M., \& Pandey, R. (2018). Board composition, sustainability committee and corporate social and environmental performance in Australia. Pacific Accounting Review, 30(4), 517540. https://doi.org/10.1108/PAR-12-2017-0107

Biswas, P. K., Roberts, H., \& Whiting, R. H. (2021). Female directors and CSR disclosure in Bangladesh: The role of family affiliation. Meditari Accountancy Research. https://doi.org/10.1108/ MEDAR-10-2019-0587

Boukattaya, S., \& Omri, A. (2021). Impact of board gender diversity on corporate social responsibility and irresponsibility: Empirical evidence from France. Sustainability, 13(9), 4712. https://doi.org/ $10.3390 /$ su13094712 
Boyd, D. E., Spekman, R. E., Kamauff, J. W., \& Werhane, P. (2007). Corporate social responsibility in global supply chains: A procedural justice perspective. Long Range Planning, 40(3), 341-356. https://doi.org/10.1016/j.lrp.2006.12.007

Bravo, F., \& Reguera-Alvarado, N. (2018). Sustainable development disclosure: Environmental, social, and governance reporting and gender diversity in the audit committee. Business Strategy and the Environment. https://doi.org/10.1002/bse.2258

Bristy, H. J., How, J., \& Verhoeven, P. (2020). Gender diversity: The corporate social responsibility and financial performance nexus. International Journal of Managerial Finance. https://doi.org/10. 1108/IJMF-04-2020-0176

Bruna, M. G., Dang, R., \& Vo, L.-C. (2014). Women directors and CSR: Evidence from corporate social disclosure of French companies. In M. Karataş-Ozkan, K. Nicolopoulou, \& M. Özbilgin (Eds.), Corporate Social Responsibility and Human Resource Management (pp. 82-111). Edward Elgar Publishing.

Brunninge, O., Nordqvist, M., \& Wiklund, J. (2007). Corporate governance and strategic change in SMEs: The effects of ownership, board composition and top management teams. Small Business Economics, 29(3), 295-308. https://doi.org/10.1007/s11187-006-9021-2

Bryman, A. (2008). Of methods and methodology. Qualitative Research in Organizations and Management: An International Journal, 3(2), 159-168. https://doi.org/10.1108/17465640810900568

Buallay, A., Hamdan, R., Barone, E., \& Hamdan, A. (2020). Increasing female participation on boards: Effects on sustainability reporting. International Journal of Finance \& Economics. https://doi.org/ $10.1002 /$ ijfe. 2141

Buertey, S. (2021). Board gender diversity and corporate social responsibility assurance: The moderating effect of ownership concentration. Corporate Social Responsibility and Environmental Management. https://doi.org/10.1002/csr.2121

Buil-Fabregà, M., del Alonso-Almeida, M., \& M., \& Bagur-Femenías, L. . (2017). Individual dynamic managerial capabilities: Influence over environmental and social commitment under a gender perspective. Journal of Cleaner Production, 151, 371-379. https://doi.org/10.1016/j.jclepro.2017.03. 081

Burkhardt, K., Nguyen, P., \& Poincelot, E. (2020). Agents of change: Women in top management and corporate environmental performance. Corporate Social Responsibility and Environmental Management. https://doi.org/10.1002/csr.1907

Byron, K., \& Post, C. (2016). Women on boards of directors and corporate social performance: A metaanalysis. Corporate Governance: An International Review, 24(4), 428-442. https://doi.org/10. 1111/corg. 12165

Campanella, F., Serino, L., Crisci, A., \& D’Ambra, A. (2021). The role of corporate governance in environmental policy disclosure and sustainable development. Generalized estimating equations in longitudinal count data analysis. Corporate Social Responsibility and Environmental Management, 28(1), 474-484. https://doi.org/10.1002/csr.2062

Campopiano, G., Rinaldi, F. R., Sciascia, S., \& De Massis, A. (2019). Family and non-family women on the board of directors: Effects on corporate citizenship behavior in family-controlled fashion firms. Journal of Cleaner Production, 214, 41-51. https://doi.org/10.1016/j.jclepro.2018.12.319

Caputo, A., Marzi, G., Pellegrini, M. M., \& Rialti, R. (2018). Conflict management in family businesses: A bibliometric analysis and systematic literature review. International Journal of Conflict Management, 29(4), 519-542. https://doi.org/10.1108/IJCMA-02-2018-0027

Carroll, A. B. (1979). A three-dimensional conceptual model of corporate performance. The Academy of Management Review, 4(4), 497. https://doi.org/10.2307/257850

Chams, N., \& García-Blandón, J. (2019). Sustainable or not sustainable? The role of the board of directors. Journal of Cleaner Production, 226, 1067-1081. https://doi.org/10.1016/j.jclepro.2019.04. 118

Chong, L.-L., Ong, H.-B., \& Tan, S.-H. (2018). Corporate risk-taking and performance in Malaysia: The effect of board composition, political connections and sustainability practices. Corporate Governance: The International Journal of Business in Society. https://doi.org/10.1108/CG-05-2017-0095

Činčalová, S., \& Hedija, V. (2020). Firm characteristics and corporate social responsibility: The case of Czech transportation and storage industry. Sustainability, 12(5), 1992. https://doi.org/10.3390/ su12051992

Cordeiro, J. J., Profumo, G., \& Tutore, I. (2020). Board gender diversity and corporate environmental performance: The moderating role of family and dual-class majority ownership structures. Business Strategy and the Environment, 29(3), 1127-1144. https://doi.org/10.1002/bse.2421 
Cosma, S., Schwizer, P., Nobile, L., \& Leopizzi, R. (2021). Environmental attitude in the board. Who are the "green directors"? Evidences from Italy. Business Strategy and the Environment. https://doi. org/10.1002/bse. 2807

Courrent, J.-M., Spence, M., \& Gherib, J. (2016). Profil du dirigeant et adhésion à l'argument économique de la responsabilité sociale en petite entreprise [Owner-manager's profile and agreement with the business case argument of social responsibility in small businesses]. Revue Internationale P.M.E., 29(2), 31-64. https://doi.org/10.7202/1037922ar

Creswell, J. W., \& Plano Clark, V. L. (2018). Designing and conducting mixed methods research (3rd ed.). SAGE.

Criado-Gomis, A., Iniesta-Bonillo, M.-A., Cervera-Taulet, A., \& Ribeiro-Soriano, D. (2020). Women as key agents in sustainable entrepreneurship: A gender multigroup analysis of the SEO-performance relationship. Sustainability, 12(3), 1244. https://doi.org/10.3390/su12031244

Cuadrado-Ballesteros, B., Martínez-Ferrero, J., \& García-Sánchez, I. M. (2017). Board structure to enhance social responsibility development: A qualitative comparative analysis of US companies. Corporate Social Responsibility and Environmental Management, 24(6), 524-542. https://doi.org/ $10.1002 / \mathrm{csr} .1425$

Cucari, N., Esposito De Falco, S., \& Orlando, B. (2018). Diversity of board of directors and environmental social governance: Evidence from Italian listed companies. Corporate Social Responsibility and Environmental Management, 25(3), 250-266. https://doi.org/10.1002/csr.1452

Cullinan, C. P., Mahoney, L., \& Roush, P. B. (2019). Directors \& corporate social responsibility: Joint consideration of director gender and the director's role. Social and Environmental Accountability Journal, 39(2), 100-123. https://doi.org/10.1080/0969160X.2019.1586556

Dahlerup, D. (2006). The story of the theory of critical mass. Politics \& Gender. https://doi.org/10.1017/ S1743923X0624114X

de Almeida, M. F. L., \& de Melo, M. A. C. (2017). Sociotechnical regimes, technological innovation and corporate sustainability: From principles to action. Technology Analysis \& Strategic Management, 29(4), 395-413. https://doi.org/10.1080/09537325.2016.1215419

de Larrieta-Rubín Celis, I., Velasco-Balmaseda, E., de Fernández Bobadilla, S., del Mar Alonso-Almeida, M., \& Intxaurburu-Clemente, G. (2015). Does having women managers lead to increased gender equality practices in corporate social responsibility? Business Ethics: A European Review, 24(1), 91-110. https://doi.org/10.1111/beer.12081

De Masi, S., Słomka-Gołębiowska, A., Becagli, C., \& Paci, A. (2021). Toward sustainable corporate behavior: The effect of the critical mass of female directors on environmental, social, and governance disclosure. Business Strategy and the Environment, 30(4), 1865-1878. https://doi.org/10. $1002 / \mathrm{bse} .2721$

de Villiers, C., \& Dimes, R. (2021). Determinants, mechanisms and consequences of corporate governance reporting: A research framework. Journal of Management and Governance, 25(1), 7-26. https://doi.org/10.1007/s10997-020-09530-0

del Carmen, María, Martínez, Valls, Cervantes, Pedro Antonio Martín., \& Rambaud, Salvador Cruz. (2020). Women on corporate boards and sustainable development in the American and European markets: Is there a limit to gender policies? Corporate Social Responsibility and Environmental Management, 27(6), 2642-2656. https://doi.org/10.1002/csr.1989

del Carmen, María, Martínez, Valls, Rambaud, Salvador Cruz, \& Oller, Isabel María Parra. (2019). Gender policies on board of directors and sustainable development. Corporate Social Responsibility and Environmental Management. https://doi.org/10.1002/csr.1825

Deschênes, S., Rojas, M., Boubacar, H., Prud'homme, B., \& Ouedraogo, A. (2015). The impact of board traits on the social performance of Canadian firms. Corporate Governance, 15(3), 293-305. https:// doi.org/10.1108/CG-08-2014-0097

Dienes, D., \& Velte, P. (2016). The impact of supervisory board composition on CSR reporting. Evidence from the German two-tier system. Sustainability, 8(1), 63. https://doi.org/10.3390/su8010063

Dilling, P. F. A., \& Caykoylu, S. (2019). Determinants of companies that disclose high-quality integrated reports. Sustainability, 11(13), 3744. https://doi.org/10.3390/su11133744

Dwekat, A., Seguí-Mas, E., Tormo-Carbó, G., \& Carmona, P. (2020). Corporate governance configurations and corporate social responsibility disclosure: Qualitative comparative analysis of audit committee and board characteristics. Corporate Social Responsibility and Environmental Management, 27(6), 2879-2892. https://doi.org/10.1002/csr.2009 
Dyduch, J., \& Krasodomska, J. (2017). Determinants of corporate social responsibility disclosure: An empirical study of Polish listed companies. Sustainability, 9(11), 1934. https://doi.org/10.3390/ su9111934

Eberhardt-Toth, E. (2017). Who should be on a board corporate social responsibility committee? Journal of Cleaner Production, 140, 1926-1935. https://doi.org/10.1016/j.jclepro.2016.08.127

Elmaghrabi, M. E. (2021). CSR committee attributes and CSR performance: UK evidence. Corporate Governance: The International Journal of Business in Society. https://doi.org/10.1108/ CG-01-2020-0036

Elmagrhi, M. H., Ntim, C. G., Elamer, A. A., \& Zhang, Q. (2019). A study of environmental policies and regulations, governance structures, and environmental performance: The role of female directors. Business Strategy and the Environment, 28(1), 206-220. https://doi.org/10.1002/bse.2250

Endrikat, J., de Villiers, C., Guenther, T. W., \& Guenther, E. M. (2020). Board characteristics and corporate social responsibility: A meta-analytic investigation. Business \& Society. https://doi.org/10. 1177/0007650320930638

Fahad, P., \& Rahman, P. M. (2020). Impact of corporate governance on CSR disclosure. International Journal of Disclosure and Governance, 17(2-3), 155-167. https://doi.org/10.1057/ s41310-020-00082-1

Fakir, A. N. M. A., \& Jusoh, R. (2020). Board gender diversity and corporate sustainability performance: Mediating role of enterprise risk management. The Journal of Asian Finance, Economics and Business, 7(6), 351-363. https://doi.org/10.13106/JAFEB.2020.VOL7.NO6.351

Fakoya, M. B., \& Nakeng, M. V. (2019). Board characteristics and sustainable energy performance of selected companies in South Africa. Sustainable Production and Consumption, 18, 190-199. https://doi.org/10.1016/j.spc.2019.02.003

Falagas, M. E., Pitsouni, E. I., Malietzis, G. A., \& Pappas, G. (2008). Comparison of PubMed, Scopus, Web of Science, and Google Scholar: Strengths and weaknesses. The FASEB Journal, 22(2), 338342. https://doi.org/10.1096/fj.07-9492LSF

Family Firm Institute. (2020). Global data points. https://my.ffi.org/page/globaldatapoints

Fernandes, S. M., Bornia, A. C., \& Nakamura, L. R. (2018). The influence of boards of directors on environmental disclosure. Management Decision. https://doi.org/10.1108/MD-11-2017-1084

Fernandez-Feijoo, B., Romero, S., \& Ruiz-Blanco, S. (2014). Women on boards: Do they affect sustainability reporting? Corporate Social Responsibility and Environmental Management, 21(6), 351364. https://doi.org/10.1002/csr.1329

Ferramosca, S., \& Verona, R. (2020). Framing the evolution of corporate social responsibility as a discipline (1973-2018): A large-scale scientometric analysis. Corporate Social Responsibility and Environmental Management, 27(1), 178-203. https://doi.org/10.1002/csr.1792

Formigoni, H., Segura, L., Gallego-Álvarez, I., \& Garcia-Sanchez, I.-M. (2020). Board of directors characteristics and disclosure practices of corporate social responsibility: A comparative study between Brazilian and Spanish companies. Social Responsibility Journal. https://doi.org/10.1108/ SRJ-01-2019-0043

Francoeur, C., Labelle, R., Balti, S., \& Bouzaidi, E. L. (2019). To what extent do gender diverse boards enhance corporate social performance? Journal of Business Ethics, 155(2), 343-357. https://doi. org/10.1007/s10551-017-3529-z

Frias-Aceituno, J. V., Rodriguez-Ariza, L., \& Garcia-Sanchez, I. M. (2013). The role of the board in the dissemination of integrated corporate social reporting: The role of the board in the dissemination of integrated report. Corporate Social Responsibility and Environmental Management, 20(4), 219-233. https://doi.org/10.1002/csr.1294

Fuadah, L. L., Dewi, K., \& Arisman, A. (2018). Determinant factors effect environmental disclosure and firm value at mining companies listed Indonesia Stock Exchange. E3S Web of Conferences, 68, 03015. https://doi.org/10.1051/e3sconf/20186803015

Galbreath, J. (2011). Are there gender-related influences on corporate sustainability? A study of women on boards of directors. Journal of Management \& Organization, 17(1), 17-38. https://doi.org/10. $1017 / \mathrm{S} 1833367200001693$

Galbreath, J. (2016). When do board and management resources complement each other? A study of effects on corporate social responsibility. Journal of Business Ethics, 136(2), 281-292. https://doi. org/10.1007/s10551-014-2519-7

Galbreath, J., \& Tisch, D. (2020). The effects of women in different roles on environmentally sustainable practices: Empirical evidence from the Australian wine industry. Australasian Journal of Environmental Management, 27(4), 434-451. https://doi.org/10.1080/14486563.2020.1838351 
Gallego-Álvarez, I., \& Pucheta-Martínez, M. C. (2020a). Environmental strategy in the global banking industry within the varieties of capitalism approach: The moderating role of gender diversity and board members with specific skills. Business Strategy and the Environment, 29(2), 347-360. https://doi.org/10.1002/bse.2368

Gallego-Álvarez, I., \& Pucheta-Martínez, M. C. (2020b). Corporate social responsibility reporting and corporate governance mechanisms: An international outlook from emerging countries. Business Strategy \& Development, 3(1), 77-97. https://doi.org/10.1002/bsd2.80

Gallego-Sosa, C., Fernández-Torres, Y., \& Gutiérrez-Fernández, M. (2020). Does gender diversity affect the environmental performance of banks? Sustainability, 12(23), 10172. https://doi.org/10.3390/ su122310172

Gangi, F., Daniele, L. M., Varrone, N., Vicentini, F., \& Coscia, M. (2021). Equity mutual funds' interest in the environmental, social and governance policies of target firms: Does gender diversity in management teams matter? Corporate Social Responsibility and Environmental Management, 28(3), 1018-1031. https://doi.org/10.1002/csr.2102

García Martín, C. J., \& Herrero, B. (2020). Do board characteristics affect environmental performance? A study of EU firms. Corporate Social Responsibility and Environmental Management, 27(1), 74-94. https://doi.org/10.1002/csr.1775

García-Sánchez, I.-M. (2020). Corporate social reporting and assurance: The state of the art. SSRN Electronic Journal. https://doi.org/10.2139/ssrn.3588470

García-Sánchez, I., Gallego-Álvarez, I., \& Zafra-Gómez, J. (2020a). Do independent, female and specialist directors promote eco-innovation and eco-design in agri-food firms? Business Strategy and the Environment. https://doi.org/10.1002/bse.2676

García-Sánchez, I.-M., Martínez-Ferrero, J., \& García-Meca, E. (2018). Board of directors and CSR in Banking: The moderating role of bank regulation and investor protection strength. Australian Accounting Review, 28(3), 428-445. https://doi.org/10.1111/auar.12199

García-Sánchez, I., Oliveira, M. C., \& Martínez-Ferrero, J. (2020b). Female directors and gender issues reporting: The impact of stakeholder engagement at country level. Corporate Social Responsibility and Environmental Management, 27(1), 369-382. https://doi.org/10.1002/csr.1811

García-Sánchez, I.-M., Suárez-Fernández, O., \& Martínez-Ferrero, J. (2019). Female directors and impression management in sustainability reporting. International Business Review, 28(2), 359374. https://doi.org/10.1016/j.ibusrev.2018.10.007

Garcia-Torea, N., Fernandez-Feijoo, B., \& de la Cuesta-González, M. (2017). The influence of ownership structure on the transparency of CSR reporting: Empirical evidence from Spain. Spanish Journal of Finance and Accounting / Revista Española De Financiación y Contabilidad, 46(3), 249-271. https://doi.org/10.1080/02102412.2016.1267451

Garde Sánchez, R., Rodríguez Bolívar, M. P., \& López Hernández, A. M. (2017). Corporate and managerial characteristics as drivers of social responsibility disclosure by state-owned enterprises. Review of Managerial Science, 11(3), 633-659. https://doi.org/10.1007/s11846-016-0199-7

Giannarakis, G. (2014). Corporate governance and financial characteristic effects on the extent of corporate social responsibility disclosure. Social Responsibility Journal, 10(4), 569-590. https://doi.org/ 10.1108/SRJ-02-2013-0008

Giannarakis, G., Konteos, G., \& Sariannidis, N. (2014). Financial, governance and environmental determinants of corporate social responsible disclosure. Management Decision, 52(10), 1928-1951. https://doi.org/10.1108/MD-05-2014-0296

Girón, A., Kazemikhasragh, A., Cicchiello, A. F., \& Panetti, E. (2020). Sustainability reporting and firms' economic performance: Evidence from Asia and Africa. Journal of the Knowledge Economy. https://doi.org/10.1007/s13132-020-00693-7

Glass, C., Cook, A., \& Ingersoll, A. R. (2016). Do women leaders promote sustainability? Analyzing the effect of corporate governance composition on environmental performance. Business Strategy and the Environment, 25(7), 495-511. https://doi.org/10.1002/bse.1879

Goebel, P., Reuter, C., Pibernik, R., Sichtmann, C., \& Bals, L. (2018). Purchasing managers' willingness to pay for attributes that constitute sustainability. Journal of Operations Management. https://doi. org/10.1016/j.jom.2018.08.002

Govindan, K., Kilic, M., Uyar, A., \& Karaman, A. S. (2021). Drivers and value-relevance of CSR performance in the logistics sector: A cross-country firm-level investigation. International Journal of Production Economics, 231, 107835. https://doi.org/10.1016/j.ijpe.2020.107835 
Goyal, P., Rahman, Z., \& Kazmi, A. A. (2013). Corporate sustainability performance and firm performance research: Literature review and future research agenda. Management Decision, 51(2), 361379. https://doi.org/10.1108/00251741311301867

Graafland, J. (2020). Women in management and sustainable development of SMEs: Do relational environmental management instruments matter? Corporate Social Responsibility and Environmental Management, 27(5), 2320-2328. https://doi.org/10.1002/csr.1966

Guerrero-Villegas, J., Pérez-Calero, L., Hurtado-González, J., \& Giráldez-Puig, P. (2018). Board attributes and corporate social responsibility disclosure: A meta-analysis. Sustainability, 10(12), 4808. https://doi.org/10.3390/su10124808

Gulzar, M. A., Cherian, J., Hwang, J., Jiang, Y., \& Sial, M. S. (2019). The impact of board gender diversity and foreign institutional investors on the corporate social responsibility (CSR) engagement of Chinese listed companies. Sustainability, 11(2), 307. https://doi.org/10.3390/su11020307

Guping, C., Safdar Sial, M., Wan, P., Badulescu, A., Badulescu, D., \& Vianna Brugni, T. (2020). Do board gender diversity and non-executive directors affect CSR Reporting? Insight from agency theory perspective. Sustainability, 12(20), 8597. https://doi.org/10.3390/su12208597

Hafsi, T., \& Turgut, G. (2013). Boardroom diversity and its effect on social performance: Conceptualization and empirical evidence. Journal of Business Ethics, 112(3), 463-479. https://doi.org/10.1007/ s10551-012-1272-z

Hambrick, D. C. (2007). Upper echelons theory: An update. The Academy of Management Review, 32(2), 334-343.

Hambrick, D. C., \& Mason, P. A. (1984). Upper echelons: The organization as a reflection of its top managers. The Academy of Management Review, 9(2), 193-206. https://doi.org/10.2307/258434

Haque, F. (2017). The effects of board characteristics and sustainable compensation policy on carbon performance of UK firms. The British Accounting Review, 49(3), 347-364. https://doi.org/10.1016/j. bar.2017.01.001

Hollindale, J., Kent, P., Routledge, J., \& Chapple, L. (2019). Women on boards and greenhouse gas emission disclosures. Accounting \& Finance, 59(1), 277-308. https://doi.org/10.1111/acfi.12258

Hosain, M. S. (2020). The relationship between corporate governance and corporate social responsibility expenditure in Bangladesh: Moderating role of firm value. Indian Journal of Corporate Governance, 13(2), 190-209. https://doi.org/10.1177/0974686220965330

Hossain, M., Farooque, O. A., Momin, M. A., \& Almotairy, O. (2017). Women in the boardroom and their impact on climate change related disclosure. Social Responsibility Journal, 13(4), 828-855. https://doi.org/10.1108/SRJ-11-2016-0208

Hu, L., \& Yang, D. (2021). Female board directors and corporate environmental investment: A contingent view. Sustainability, 13(4), 1975. https://doi.org/10.3390/su13041975

Huang, S. K. (2013). The Impact of CEO characteristics on corporate sustainable development. Corporate Social Responsibility and Environmental Management, 20(4), 234-244. https://doi.org/10. $1002 / \mathrm{csr} .1295$

Hyun, E., Yang, D., Jung, H., \& Hong, K. (2016). Women on boards and corporate social responsibility. Sustainability, 8(4), 300. https://doi.org/10.3390/su8040300

Issa, A., \& Fang, H.-X. (2019). The impact of board gender diversity on corporate social responsibility in the Arab Gulf states. Gender in Management: An International Journal, 34(7), 577-605. https:// doi.org/10.1108/GM-07-2018-0087

Jahid, Md. A., Rashid, Md. H. U., Hossain, S. Z., Haryono, S., \& Jatmiko, B. (2020). Impact of corporate governance mechanisms on corporate social responsibility disclosure of publicly-listed banks in Bangladesh. The Journal of Asian Finance, Economics and Business, 7(6), 61-71. https://doi.org/ 10.13106/JAFEB.2020.VOL7.NO6.061

Javaid Lone, E., Ali, A., \& Khan, I. (2016). Corporate governance and corporate social responsibility disclosure: Evidence from Pakistan. Corporate Governance: The International Journal of Business in Society, 16(5), 785-797. https://doi.org/10.1108/CG-05-2016-0100

Jiang, X., \& Akbar, A. (2018). Does increased representation of female executives improve corporate environmental investment? Evidence from China. Sustainability, 10(12), 4750. https://doi.org/10. $3390 /$ su10124750

Jizi, M. (2017). The influence of board composition on sustainable development disclosure. Business Strategy and the Environment, 26(5), 640-655. https://doi.org/10.1002/bse.1943

Johnsen, T. E., Miemczyk, J., \& Howard, M. (2017). A systematic literature review of sustainable purchasing and supply research: Theoretical perspectives and opportunities for IMP-based research. Industrial Marketing Management, 61, 130-143. https://doi.org/10.1016/j.indmarman.2016.03.003 
Jouber, H. (2021). Is the effect of board diversity on CSR diverse? New insights from one-tier vs two-tier corporate board models. Corporate Governance: The International Journal of Business in Society, 21(1), 23-61. https://doi.org/10.1108/CG-07-2020-0277

Kabir, R., \& Thai, H. M. (2021). Key factors determining corporate social responsibility practices of Vietnamese firms and the joint effects of foreign ownership. Journal of Multinational Financial Management, 59, 100676. https://doi.org/10.1016/j.mulfin.2020.100676

Kabongo, J. D., Chang, K., \& Li, Y. (2013). The impact of operational diversity on corporate philanthropy: An empirical study of U.S. companies. Journal of Business Ethics, 116(1), 49-65. https:// doi.org/10.1007/s10551-012-1445-9

Kassinis, G., Panayiotou, A., Dimou, A., \& Katsifaraki, G. (2016). Gender and environmental sustainability: A longitudinal analysis. Corporate Social Responsibility and Environmental Management, 23(6), 399-412. https://doi.org/10.1002/csr.1386

Kathy Rao, K., Tilt, C. A., \& Lester, L. H. (2012). Corporate governance and environmental reporting: An Australian study. Corporate Governance: The International Journal of Business in Society, 12(2), 143-163. https://doi.org/10.1108/14720701211214052

Khan, E. A., Dewan, M. N. A., \& Chowdhury, Md. M. H. (2016). Reflective or formative measurement model of sustainability factor? A three industry comparison. Corporate Ownership and Control, 13(2), 83-92. https://doi.org/10.22495/cocv13i2p9

Khan, H. (2010). The effect of corporate governance elements on corporate social responsibility (CSR) reporting: Empirical evidence from private commercial banks of Bangladesh. International Journal of Law and Management, 52(2), 82-109. https://doi.org/10.1108/17542431011029406

Khan, I., Khan, I., \& Saeed, B. (2019). Does board diversity affect quality of corporate social responsibility disclosure? Evidence from Pakistan. Corporate Social Responsibility and Environmental Management. https://doi.org/10.1002/csr.1753

Khan, I., Khan, I., \& Senturk, I. (2019b). Board diversity and quality of CSR disclosure: Evidence from Pakistan. Corporate Governance: The International Journal of Business in Society, 19(6), 11871203. https://doi.org/10.1108/CG-12-2018-0371

Khatib, S. F. A., Abdullah, D. F., Elamer, A. A., \& Abueid, R. (2020). Nudging toward diversity in the boardroom: A systematic literature review of board diversity of financial institutions. Business Strategy and the Environment. https://doi.org/10.1002/bse. 2665

Kılıç, M., \& Kuzey, C. (2019). The effect of corporate governance on carbon emission disclosures: Evidence from Turkey. International Journal of Climate Change Strategies and Management, 11(1), 35-53. https://doi.org/10.1108/IJCCSM-07-2017-0144

Kilincarslan, E., Elmagrhi, M. H., \& Li, Z. (2020). Impact of governance structures on environmental disclosures in the Middle East and Africa. Corporate Governance: The International Journal of Business in Society, 20(4), 739-763. https://doi.org/10.1108/CG-08-2019-0250

Kumar, A., Paul, J., \& Unnithan, A. B. (2020). 'Masstige' marketing: A review, synthesis and research agenda. Journal of Business Research, 113, 384-398. https://doi.org/10.1016/j.jbusres.2019.09.030

Lagasio, V., \& Cucari, N. (2019). Corporate governance and environmental social governance disclosure: A meta-analytical review. Corporate Social Responsibility and Environmental Management, 26(4), 701-711. https://doi.org/10.1002/csr.1716

Landry, E. E., Bernardi, R. A., \& Bosco, S. M. (2016). Recognition for sustained corporate social responsibility: Female directors make a difference. Corporate Social Responsibility and Environmental Management, 23(1), 27-36. https://doi.org/10.1002/csr.1358

Li, J., Zhao, F., Chen, S., Jiang, W., Liu, T., \& Shi, S. (2017). Gender diversity on boards and firms' environmental policy: Gender diversity on boards. Business Strategy and the Environment, 26(3), 306-315. https://doi.org/10.1002/bse.1918

Liao, L., Lin, T., \& Zhang, Y. (2018). Corporate board and corporate social responsibility assurance: Evidence from China. Journal of Business Ethics, 150(1), 211-225. https://doi.org/10.1007/ s10551-016-3176-9

Lopatta, K., Böttcher, K., Lodhia, S. K., \& Tideman, S. A. (2020). The relationship between gender diversity and employee representation at the board level and non-financial performance: A crosscountry study. The International Journal of Accounting, 55(01), 2050001. https://doi.org/10.1142/ S1094406020500018

Loukil, N., Yousfi, O., \& Yerbanga, R. (2019). Does gender diversity on boards influence stock market liquidity? Empirical evidence from the French market. Corporate Governance: The International Journal of Business in Society, 19(4), 669-703. https://doi.org/10.1108/CG-09-2018-0291 
Lu, J., \& Herremans, I. M. (2019). Board gender diversity and environmental performance: An industries perspective. Business Strategy and the Environment, 28(7), 1449-1464. https://doi.org/10.1002/ bse. 2326

Lu, J., Ren, L., Qiao, J., Lin, W., \& He, Y. (2019). Female executives and corporate social responsibility performance: A dual perspective of differences in institutional environment and heterogeneity of foreign experience [Vadovių ir i̇monių socialinės atsakomybės efektyvumas: Institucinės aplinkos skirtumų ir patirties užsienyje heterogeniškumo aspektai]. Transformations in Business and Economics, 18(2), 174-196.

Lu, J., Ren, L., Zhang, C., Wang, C., Petkeviciute, N., \& Streimikis, J. (2020). Gender difference in corporate social responsibility implementation in Lithuanian SMEs. Oeconomia Copernicana, 11(3), 549-569. https://doi.org/10.24136/oc.2020.023

Lu, Q., Chen, S., \& Chen, P. (2020b). The relationship between female top managers and corporate social responsibility in China: The moderating role of the marketization level. Sustainability, 12(18), 7730. https://doi.org/10.3390/su12187730

Mahmood, M., \& Orazalin, N. (2017). Green governance and sustainability reporting in Kazakhstan's oil, gas, and mining sector: Evidence from a former USSR emerging economy. Journal of Cleaner Production, 164, 389-397. https://doi.org/10.1016/j.jclepro.2017.06.203

Mahmood, Z., Kouser, R., Ali, W., Ahmad, Z., \& Salman, T. (2018). Does corporate governance affect sustainability disclosure? A Mixed Methods Study. Sustainability, 10(1), 207. https://doi.org/10. 3390/su10010207

Majumder, Md. T. H., Akter, A., \& Li, X. (2017). Corporate governance and corporate social disclosures: A meta-analytical review. International Journal of Accounting \& Information Management, 25(4), 434-458. https://doi.org/10.1108/IJAIM-01-2017-0005

Manita, R., Bruna, M. G., Dang, R., \& Houanti, L. (2018). Board gender diversity and ESG disclosure: Evidence from the USA. Journal of Applied Accounting Research, 19(2), 206-224. https://doi.org/ 10.1108/JAAR-01-2017-0024

Martínez León, I. M., Arcas León, N., \& García Hernández, M. (2011). La influencia de género sobre la responsabilidad social empresariales en las entidades de economía social [The influence of gender on corporate social responsibility in social economy enterprises]. REVESCO. Revista De Estudios Cooperativos, 105, 143-172. https://doi.org/10.5209/rev_REVE.2011.v105.6

Martínez-Ferrero, J., Eryilmaz, M., \& Colakoglu, N. (2020). How does board gender diversity influence the likelihood of becoming a UN Global Compact signatory? The mediating effect of the CSR committee. Sustainability, 12(10), 4329. https://doi.org/10.3390/su12104329

Matuszak, Ł, Różańska, E., \& Macuda, M. (2019). The impact of corporate governance characteristics on banks' corporate social responsibility disclosure: Evidence from Poland. Journal of Accounting in Emerging Economies, 9(1), 75-102. https://doi.org/10.1108/JAEE-04-2017-0040

McGuinness, P. B., Vieito, J. P., \& Wang, M. (2017). The role of board gender and foreign ownership in the CSR performance of Chinese listed firms. Journal of Corporate Finance, 42, 75-99. https:// doi.org/10.1016/j.jcorpfin.2016.11.001

Mengis, H. (2020). The role of individuals, incumbents, and failure in catch-up processes: A systematic literature review. Technology Analysis \& Strategic Management. https://doi.org/10.1080/09537325. 2020.1790515

Moher, D., Liberati, A., Tetzlaff, J., \& Altman, D. G. (2009). Preferred reporting items for systematic reviews and meta-analyses: The PRISMA statement. BMJ. https://doi.org/10.1136/bmj.b2535

Montiel, I. (2008). Corporate social responsibility and corporate sustainability: Separate pasts, common futures. Organization \& Environment, 21(3), 245-269. https://doi.org/10.1177/1086026608321329

Mousa, G. A., Desoky, A. M., \& Khan, G. U. (2018). The association between corporate governance and corporate social responsibility disclosure-evidence from gulf cooperation council countries. Academy of Accounting and Financial Studies Journal, 22(4), 1-18.

Naciti, V., Cesaroni, F., \& Pulejo, L. (2021). Corporate governance and sustainability: A review of the existing literature. Journal of Management and Governance. https://doi.org/10.1007/ s10997-020-09554-6

Nadeem, M. (2020). Corporate governance and supplemental environmental projects: A restorative justice approach. Journal of Business Ethics. https://doi.org/10.1007/s10551-020-04561-x 
Nadeem, M., Bahadar, S., Gull, A. A., \& Iqbal, U. (2020). Are women eco-friendly? Board gender diversity and environmental innovation. Business Strategy and the Environment, 29(8), 3146-3161. https://doi.org/10.1002/bse.2563

Nadeem, M., Zaman, R., \& Saleem, I. (2017). Boardroom gender diversity and corporate sustainability practices: Evidence from Australian Securities Exchange listed firms. Journal of Cleaner Production, 149, 874-885. https://doi.org/10.1016/j.jclepro.2017.02.141

Naveed, K., Voinea, C. L., Ali, Z., Rauf, F., \& Fratostiteanu, C. (2021). Board gender diversity and corporate social performance in different industry groups: Evidence from China. Sustainability, 13(6), 3142. https://doi.org/10.3390/su13063142

Nielsen, S., \& Huse, M. (2010). Women directors' contribution to board decision-making and strategic involvement: The role of equality perception. European Management Review, 7(1), 16-29. https:// doi.org/10.1057/emr.2009.27

Nguyen, T. H. H., Elmagrhi, M. H., Ntim, C. G., \& Wu, Y. (2021). Environmental performance, sustainability, governance and financial performance: Evidence from heavily polluting industries in China. Business Strategy and the Environment. https://doi.org/10.1002/bse.2748

Nguyen, T. H. H., Ntim, C. G., \& Malagila, J. K. (2020). Women on corporate boards and corporate financial and non-financial performance: A systematic literature review and future research agenda. International Review of Financial Analysis, 71, 101554. https://doi.org/10.1016/j.irfa.2020.101554

Nuber, C., \& Velte, P. (2021). Board gender diversity and carbon emissions: European evidence on curvilinear relationships and critical mass. Business Strategy and the Environment, 30(4), 1958-1992. https://doi.org/10.1002/bse.2727

Ong, T., \& Djajadikerta, H. G. (2018). Corporate governance and sustainability reporting in the Australian resources industry: An empirical analysis. Social Responsibility Journal, 16(1), 1-14. https:// doi.org/10.1108/SRJ-06-2018-0135

Orazalin, N., \& Baydauletov, M. (2020). Corporate social responsibility strategy and corporate environmental and social performance: The moderating role of board gender diversity. Corporate Social Responsibility and Environmental Management. https://doi.org/10.1002/csr.1915

Orazalin, N., \& Mahmood, M. (2021). Toward sustainable development: Board characteristics, country governance quality, and environmental performance. Business Strategy and the Environment. https://doi.org/10.1002/bse.2820

Pan, C., Guo, H., Jiang, Y., Wang, H., \& Qi, W. (2020). The double effects of female executives' participation on corporate sustainable competitive advantage through unethical environmental behavior and proactive environmental strategy. Business Strategy and the Environment. https://doi.org/10. $1002 / \mathrm{bse} .2505$

Paul, J., \& Criado, A. R. (2020). The art of writing literature review: What do we know and what do we need to know? International Business Review, 29(4), 101717. https://doi.org/10.1016/j.ibusrev. 2020.101717

Peng, X., Yang, Z., Shao, J., \& Li, X. (2021). Board diversity and corporate social responsibility disclosure of multinational corporations. Applied Economics. https://doi.org/10.1080/00036846.2021. 1910620

Post, C., Rahman, N., \& McQuillen, C. (2015). From board composition to corporate environmental performance through sustainability-themed alliances. Journal of Business Ethics, 130(2), 423-435. https://doi.org/10.1007/s10551-014-2231-7

Post, C., Rahman, N., \& Rubow, E. (2011). Green governance: Boards of directors' composition and environmental corporate social responsibility. Business \& Society, 50(1), 189-223. https://doi.org/ $10.1177 / 0007650310394642$

Prabowo, M. A., Jamin, M., Saputro, D. J., Mufraini, A., \& Agustia, D. (2017). Female executive officers and corporate social responsibility disclosure: Evidence from the banking industry in an emerging market. Journal for Global Business Advancement, 10(6), 631. https://doi.org/10.1504/JGBA. 2017.091944

Provasi, R., \& Harasheh, M. (2020). Gender diversity and corporate performance: Emphasis on sustainability performance. Corporate Social Responsibility and Environmental Management. https://doi. org/10.1002/csr.2037

Prudêncio, P., Forte, H., Crisóstomo, V., \& Vasconcelos, A. (2021). Effect of Diversity in the Board of Directors and Top Management Team on Corporate Social Responsibility. Brazilian Business Review, 18(2), 118-139. https://doi.org/10.15728/bbr.2021.18.2.1 
Przychodzen, W., Gómez-Bezares, F., \& Przychodzen, J. (2018). Green information technologies practices and financial performance - The empirical evidence from German publicly traded companies. Journal of Cleaner Production, 201, 570-579. https://doi.org/10.1016/j.jclepro.2018.08.081

Pucheta-Martínez, M. C., \& Gallego-Álvarez, I. (2019). An international approach of the relationship between board attributes and the disclosure of corporate social responsibility issues. Corporate Social Responsibility and Environmental Management, 26(3), 612-627. https://doi.org/10.1002/ csr. 1707

Quintana-García, C., Marchante-Lara, M., \& Benavides-Chicón, C. G. (2018). Social responsibility and total quality in the hospitality industry: Does gender matter? Journal of Sustainable Tourism, 26(5), 722-739. https://doi.org/10.1080/09669582.2017.1401631

Qureshi, M. A., Kirkerud, S., Theresa, K., \& Ahsan, T. (2020). The impact of sustainability (environmental, social, and governance) disclosure and board diversity on firm value: The moderating role of industry sensitivity. Business Strategy and the Environment, 29(3), 1199-1214. https://doi.org/10. 1002/bse. 2427

Ramon-Llorens, M. C., Garcia-Meca, E., \& Pucheta-Martínez, M. C. (2021). Female directors on boards. The impact of faultlines on CSR reporting. Sustainability Accounting, Management and Policy Journal, 12(1), 156-183. https://doi.org/10.1108/SAMPJ-07-2019-0273

Rao, K. K., \& Tilt, C. (2016a). Board diversity and CSR reporting: An Australian study. Meditari Accountancy Research, 24(2), 182-210. https://doi.org/10.1108/MEDAR-08-2015-0052

Rao, K. K., \& Tilt, C. (2016b). Board composition and corporate social responsibility: The role of diversity, gender, strategy and decision making. Journal of Business Ethics, 138(2), 327-347. https:// doi.org/10.1007/s10551-015-2613-5

Rao, K. K., \& Tilt, C. (2020). Gender and CSR decisions: Perspectives from Australian boards. Meditari Accountancy Research. https://doi.org/10.1108/MEDAR-11-2019-0609

Rehman, S., Orij, R., \& Khan, H. (2020). The search for alignment of board gender diversity, the adoption of environmental management systems, and the association with firm performance in Asian firms. Corporate Social Responsibility and Environmental Management, 27(5), 2161-2175. https:// doi.org/10.1002/csr.1955

Rejeb, W. B. (2017). Empirical evidence on corporate governance impact on CSR disclosure in developing economies: The Tunisian and Egyptian contexts. In D. Jamali (Ed.), Comparative Perspectives on Global Corporate Social Responsibility. IGI Global.

Reyes Bastidas, C., del Briano-Turrent, G., \& C. . (2018). Las mujeres en posiciones de liderazgo y la sustentabilidad empresarial: Evidencia en empresas cotizadas de Colombia y Chile [Women in leadership positions and corporate sustainability: evidence on listed companies from Colombia and Chile]. Estudios Gerenciales. https://doi.org/10.18046/j.estger.2018.149.2877

Romano, M., Cirillo, A., Favino, C., \& Netti, A. (2020). ESG (Environmental, Social and Governance) performance and board gender diversity: The moderating role of CEO duality. Sustainability, 12(21), 9298. https://doi.org/10.3390/su12219298

Saheed Olanrewaju, I., Kayode Ishola, A., Olawale Nurudeen, S., \& Abubakar, Ayuba. (2020). Impact of board diversity on corporate social responsibility of listed oil and gas firms in Nigeria. International Journal of Management and Sustainability, 9(4), 194-206. https://doi.org/10.18488/journal. 11.2020.94.194.206

Said, R. M., Shen, L. T., Nahar, H. S., \& Senik, R. (2018). Board compositions and social reporting: Evidence from Malaysia. International Journal of Managerial and Financial Accounting, 10(2), 128. https://doi.org/10.1504/IJMFA.2018.091661

Sanan, N. K. (2016). Board gender diversity, financial and social performance of Indian firms. Vision: The Journal of Business Perspective, 20(4), 361-367. https://doi.org/10.1177/0972262916673006

Sancho, M. P. L., Jorge, M. L., \& Madueño, J. H. (2017). Characterisation of CSR practices in Spanish SMEs through a cluster analysis. International Journal of Management and Enterprise Development, 16(4), 308. https://doi.org/10.1504/IJMED.2017.086912

Saunila, M., Rantala, T., Ukko, J., \& Havukainen, J. (2019). Why invest in green technologies? Sustainability engagement among small businesses. Technology Analysis \& Strategic Management, 31(6), 653-666. https://doi.org/10.1080/09537325.2018.1542671

Setó-Pamies, D. (2015). The relationship between women directors and corporate social responsibility. Corporate Social Responsibility and Environmental Management, 22(6), 334-345. https://doi.org/ $10.1002 /$ csr. 1349 
Shahbaz, M., Karaman, A. S., Kilic, M., \& Uyar, A. (2020). Board attributes, CSR engagement, and corporate performance: What is the nexus in the energy sector? Energy Policy, 143, 111582. https:// doi.org/10.1016/j.enpol.2020.111582

Sharma, S., \& Henriques, I. (2005). Stakeholder influences on sustainability practices in the Canadian forest products industry. Strategic Management Journal, 26(2), 159-180. https://doi.org/10.1002/ smj.439

Shaukat, A., Qiu, Y., \& Trojanowski, G. (2016). Board attributes, corporate social responsibility strategy, and corporate environmental and social performance. Journal of Business Ethics, 135(3), 569-585. https://doi.org/10.1007/s10551-014-2460-9

Shoham, A., Almor, T., Lee, S. M., \& Ahammad, M. F. (2017). Encouraging environmental sustainability through gender: A micro-foundational approach using linguistic gender marking. Journal of Organizational Behavior, 38(9), 1356-1379. https://doi.org/10.1002/job.2188

Tamimi, N., \& Sebastianelli, R. (2017). Transparency among S\&P 500 companies: An analysis of ESG disclosure scores. Management Decision, 55(8), 1660-1680. https://doi.org/10.1108/ MD-01-2017-0018

Tapver, T., Laidroo, L., \& Gurvitš-Suits, N. A. (2020). Banks' CSR reporting - Do women have a say? Corporate Governance: The International Journal of Business in Society, 20(4), 639-651. https:// doi.org/10.1108/CG-11-2019-0338

Thomas, D. R. (2006). A general inductive approach for analyzing qualitative evaluation data. American Journal of Evaluation, 27(2), 237-246. https://doi.org/10.1177/1098214005283748

Tingbani, I., Chithambo, L., Tauringana, V., \& Papanikolaou, N. (2020). Board gender diversity, environmental committee and greenhouse gas voluntary disclosures. Business Strategy and the Environment. https://doi.org/10.1002/bse.2495

Tranfield, D., Denyer, D., \& Smart, P. (2003). Towards a methodology for developing evidence-Informed management knowledge by means of systematic review. British Journal of Management, 14(3), 207-222. https://doi.org/10.1111/1467-8551.00375

Tshetshema, C. T., \& Chan, K.-Y. (2020). A systematic literature review of the relationship between demographic diversity and innovation performance at team-level. Technology Analysis \& Strategic Management, 32(8), 955-967. https://doi.org/10.1080/09537325.2020.1730783

Ullah, M. S., Muttakin, M. B., \& Khan, A. (2019). Corporate governance and corporate social responsibility disclosures in insurance companies. International Journal of Accounting \& Information Management, 27(2), 284-300. https://doi.org/10.1108/IJAIM-10-2017-0120

Uyar, A., Kilic, M., Koseoglu, M. A., Kuzey, C., \& Karaman, A. S. (2020). The link among board characteristics, corporate social responsibility performance, and financial performance: Evidence from the hospitality and tourism industry. Tourism Management Perspectives. https://doi.org/10.1016/j. tmp.2020.100714

Uyar, A., Kuzey, C., Kilic, M., \& Karaman, A. S. (2021). Board structure, financial performance, corporate social responsibility performance, CSR committee, and CEO duality: Disentangling the connection in healthcare. Corporate Social Responsibility and Environmental Management. https:// doi.org/10.1002/csr.2141

Velte, P. (2017). Does board composition have an impact on CSR reporting? Problems and Perspectives in Management, 15(2), 19-35. https://doi.org/10.21511/ppm.15(2).2017.02

Vitolla, F., Raimo, N., \& Rubino, M. (2020). Board characteristics and integrated reporting quality: An agency theory perspective. Corporate Social Responsibility and Environmental Management, 27(2), 1152-1163. https://doi.org/10.1002/csr.1879

Walker, P. H., Seuring, P. S., Sarkis, P. J., \& Klassen, P. R. (2014). Sustainable operations management: Recent trends and future directions. International Journal of Operations \& Production Management. https://doi.org/10.1108/IJOPM-12-2013-0557

Wang, B., Wang, Z., Wen, J., \& Zhang, X. T. (2021). Executive gender and firm environmental management: Evidence from CFO transitions. Sustainability, 13(7), 3653. https://doi.org/10.3390/su130 73653

WCED. (1987). Our common future. Oxford University Press.

Wei, F., Ding, B., \& Kong, Y. (2017). Female directors and corporate social responsibility: Evidence from the environmental investment of Chinese listed companies. Sustainability, 9(12), 2292. https://doi.org/10.3390/su9122292

Wiengarten, F., Lo, C. K. Y., \& Lam, J. Y. K. (2017). How does sustainability leadership affect firm performance? The choices associated with appointing a chief officer of corporate social responsibility. Journal of Business Ethics, 140(3), 477-493. https://doi.org/10.1007/s10551-015-2666-5 
Wood, W., \& Eagly, A. H. (2002). A cross-cultural analysis of the behavior of women and men: Implications for the origins of sex differences. Psychological Bulletin, 128(5), 699-727. https://doi.org/10. 1037/0033-2909.128.5.699

Wu, C., Guang, H., Xu, J., \& Wang, S. (2019). The effects of female executives on corporate philanthropy in China. Corporate Social Responsibility and Environmental Management, 26(3), 628-643. https://doi.org/10.1002/csr.1708

Xie, J., Nozawa, W., \& Managi, S. (2020). The role of women on boards in corporate environmental strategy and financial performance: A global outlook. Corporate Social Responsibility and Environmental Management. https://doi.org/10.1002/csr.1945

Yarram, S. R., \& Adapa, S. (2021). Board gender diversity and corporate social responsibility: Is there a case for critical mass? Journal of Cleaner Production, 278, 123319. https://doi.org/10.1016/j.jclep ro.2020.123319

Yaseen, H., Iskandrani, M., Ajina, A., \& Hamad, A. (2019). Investigating the relationship between board diversity \& corporate social responsibility (CSR) performance: Evidence from France. Academy of Accounting and Financial Studies Journal, 23(4), 1-11.

Yasser, Q. R., Al Mamun, A., \& Ahmed, I. (2017). Corporate social responsibility and gender diversity: Insights from Asia Pacific. Corporate Social Responsibility and Environmental Management, 24(3), 210-221. https://doi.org/10.1002/csr.1400

Yusoff, H., Abdul Jamal, A. D., \& Darus, F. (2016). The link between corporate governance and corporate social responsibility disclosures: A focus on the CSR primary dimensions. Proceedings of the 27th International Business Information Management Association Conference - Innovation Management and Education Excellence Vision 2020: From Regional Development Sustainability to Global Economic Growth, IBIMA 2016, 333-342.

Yusoff, H., Ahman, Z., \& Darus, F. (2019). The influence of corporate governance on corporate social responsibility disclosure: A focus on accountability. Academy of Accounting and Financial Studies Journal, 23(Special Issue 1), 1-16.

Zahid, M., Rahman, H. U., Ali, W., Khan, M., Alharthi, M., Imran Qureshi, M., \& Jan, A. (2020). Boardroom gender diversity: Implications for corporate sustainability disclosures in Malaysia. Journal of Cleaner Production, 244, 118683. https://doi.org/10.1016/j.jclepro.2019.118683

Zaichkowsky, J. L. (2014). Women in the board room: One can make a difference. International Journal of Business Governance and Ethics, 9(1), 91. https://doi.org/10.1504/IJBGE.2014.062774

Zaid, M. A. A., Wang, M., Adib, M., Sahyouni, A., \& Abuhijleh, T. F. (2020). Boardroom nationality and gender diversity: Implications for corporate sustainability performance. Journal of Cleaner Production, 251, 119652. https://doi.org/10.1016/j.jclepro.2019.119652

Zhang, L. (2012). Board demographic diversity, independence, and corporate social performance. Corporate Governance: The International Journal of Business in Society, 12(5), 686-700. https://doi.org/ $10.1108 / 14720701211275604$

Zhuang, Y., Chang, X., \& Lee, Y. (2018). Board composition and corporate social responsibility performance: Evidence from Chinese public firms. Sustainability, 10(8), 2752. https://doi.org/10.3390/ su 10082752

Publisher's Note Springer Nature remains neutral with regard to jurisdictional claims in published maps and institutional affiliations.

Mariasole Bannò is Assistant Professor at the University of Brescia, Italy, where she teaches in the fields of economics and management. She holds a PhD in Economics and Management of Technology in 2009 and then she was research fellow at University of Trento till 2015. From 2017 she is a European expert for the evaluation of project submitted to public funding, Horizon 2020 and SME instruments. She published several articles, a monography and book chapters in international publications, in the field of economics and management. In particular her works have been published on journals such as Journal of Small Business Management, Journal of Policy Modeling, Journal of Family Business Strategy, International Journal of Globalisation and Small Business, Regional Studies and Applied Economics Letters. Her research interests concern: family business, innovation and internationalization of firms and gender issue. She designed a new Arts-base method called Theatre Teaches and carried out at the University of Trento for the first time in the academic year 2014-2015. 
Emilia Filippi is a PhD student in Economics and Management at the University of Trento, Italy. Her research interests concern technological change, innovation and the impact on work.

Sandro Trento is Professor of Management at the University of Trento, Italy. He is Director of the School of Innovation at the University of Trento. He studied economics at the University of Rome La Sapienza, Italy; at Northwestern University, Illinois; he has been a visiting scholar at Stanford University. He has been a senior researcher at the Economic Research Department of the Bank of Italy and Chief Economist at Confindustria. Since 2017, he has been director of the ERGO-MTM Foundation. His research interests are related to corporate change; innovation management; corporate governance and family business.

\section{Authors and Affiliations}

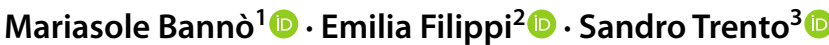

Emilia Filippi

emilia.filippi@unitn.it

Sandro Trento

sandro.trento@unitn.it

1 Department of Mechanical and Industrial Engineering, University of Brescia, Via Branze 38, 25124 Brescia, Italy

2 Doctoral School of Social Sciences, University of Trento, Via Verdi 26, 38122 Trento, Italy

3 Department of Economics and Management, University of Trento, Via Inama 5, 38122 Trento, Italy 